\title{
Technology Use By Teachers Of Deaf And Hard-Of-Hearing Students
}

Nichole K. Zirzow

West Virginia University, nkzirzow@msn.com

Follow this and additional works at: https://researchrepository.wvu.edu/etd

Part of the Special Education and Teaching Commons

\section{Recommended Citation}

Zirzow, Nichole K., "Technology Use By Teachers Of Deaf And Hard-Of-Hearing Students" (2019). Graduate Theses, Dissertations, and Problem Reports. 3885.

https://researchrepository.wvu.edu/etd/3885

This Dissertation is protected by copyright and/or related rights. It has been brought to you by the The Research Repository @ WVU with permission from the rights-holder(s). You are free to use this Dissertation in any way that is permitted by the copyright and related rights legislation that applies to your use. For other uses you must obtain permission from the rights-holder(s) directly, unless additional rights are indicated by a Creative Commons license in the record and/ or on the work itself. This Dissertation has been accepted for inclusion in WVU Graduate Theses, Dissertations, and Problem Reports collection by an authorized administrator of The Research Repository @ WVU.

For more information, please contact researchrepository@mail.wvu.edu. 


\title{
TECHNOLOGY USE BY TEACHERS OF DEAF AND HARD-OF-HEARING
} STUDENTS

\author{
Nichole K. Zirzow
}

Dissertation submitted to the College of Education and Human Services at West Virginia University in partial fulfillment of the requirements for the degree of

\author{
Doctor of Education \\ in \\ Special Education
}

Barbara Ludlow, Ed.D., Committee Co-Chairperson . D. J. Hendricks, Ed.D., Committee Co-Chairperson Alexandra Hollo, Ph.D.

Claudia M. Pagliaro, Ph.D.

\author{
Department of Special Education \\ Morgantown, West Virginia \\ 2019
}

Keywords: Deaf, Hard-of-Hearing, Technology, Survey Copyright 2019, Nichole K. Zirzow 


\title{
ABSTRACT \\ TECHNOLOGY USE BY TEACHERS OF DEAF AND HARD-OF-HEARING STUDENTS
}

\author{
Nichole K. Zirzow
}

This nationwide study explored the types and frequency of technology used by teachers of deaf and hard-of-hearing ( $\mathrm{d} / \mathrm{hh}$ ) students to design and deliver instruction, as well as the types and frequency of technology being used by teachers of $d / h$ h students to promote communication and collaboration. It also examined the extent of professional development in the area of technology use with $\mathrm{d} / \mathrm{hh}$ students, and the related challenges experienced by these teachers. The following research questions guided this study.

Research question 1. What kinds of technology do teachers of $d /$ hh students use to design and deliver academic content-based learning activities? With what frequency are these technologies being used by teachers of $\mathrm{d} / \mathrm{hh}$ students?

Research question 1a. Is there a relationship between the self-reported amount and/or kinds of technology used by teachers of $\mathrm{d} / \mathrm{hh}$ students to design and deliver academic content-based learning activities and their job position?

Research question 1b. Is there a relationship between the self-reported amount and/or kinds of technology used by teachers of $\mathrm{d} / \mathrm{hh}$ students to design and deliver academic content-based learning activities and their use of technology for obtaining additional training?

Research question 2. What kinds of technology do teachers of $\mathrm{d} / \mathrm{hh}$ students use to promote student communication and collaboration for learning? With what frequency are these technologies being used by teachers of $\mathrm{d} / \mathrm{hh}$ students?

Research question 2a. Is there a relationship between the self-reported amount and/or kinds of technology used by teachers of $\mathrm{d} / \mathrm{hh}$ students to promote student communication and collaboration for learning and their job position?

Research question $\mathbf{2 b}$. Is there a relationship between the self-reported amount and/or kinds of technology used by teachers of $\mathrm{d} / \mathrm{hh}$ students for student communication and collaboration and their use of technology for obtaining additional training?

Research question 3. Is there a relationship between the self-reported use of technology by teachers of $\mathrm{d} / \mathrm{hh}$ students for additional training and their job position?

Research question 3a. Is there a relationship between the self-reported use of technology by teachers of $\mathrm{d} / \mathrm{hh}$ students for additional training and how often their employer provides professional development in the use of instructional technology for use with deaf/hard-of-hearing students?

Research question 4. Is there a relationship between the self-reported amount and/or kinds of challenges experienced by teachers of $\mathrm{d} / \mathrm{hh}$ students and their job position? 


\section{DEDICATION}

I dedicate this work to Mildred Taylor, my paternal grandmother. Thank you for always being a model of strength and individuality. You taught me to never underestimate my abilities or worth in this world. 


\section{ACKNOWLEDGEMENTS}

The author wishes to thank Dr. Barbara Ludlow for her ongoing support and guidance. Despite being half way around the world, and multiple changes to my committee, she helped keep me focused and grounded throughout the dissertation process. I would like to also thank Dr. D.J. Hendricks and Dr. A. Hollo for thier willingness to join my committee in the eleventh hour and help guide me through the statistical analysis and further refining the document.

Thank you to my family and friends for their patience and unwavering faith in my success. Lastly, I would like to thank my amazing wife Catherine Lei Paleka-Zirzow for always reminding me to revisit my core intention for the pursuit of this degree and helping me remain steadfast in my pursuit of excellence. 


\section{TABLE OF CONTENTS}

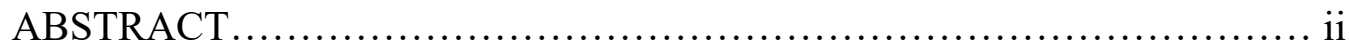

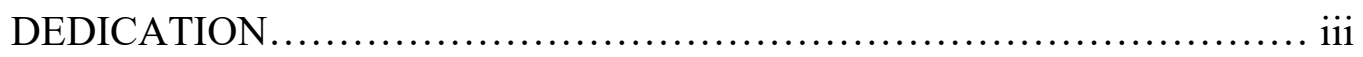

ACKNOWLEDGEMENTS .......................................... iv

TABLE OF CONTENTS ................................................. vi

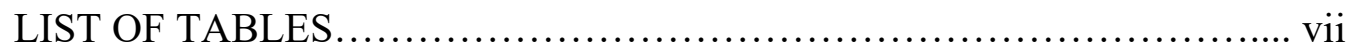

CHAPTER 1-INTRODUCTION .......................................

HISTORY .................................................... 3

TECHNOLOGY OF TODAY $\ldots \ldots \ldots \ldots \ldots \ldots \ldots \ldots \ldots \ldots \ldots \ldots \ldots . \ldots \ldots$

STATEMENT OF PROBLEM.........................................5

RESEARCH QUESTIONS.....................................6

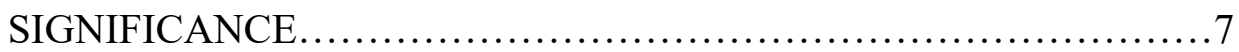

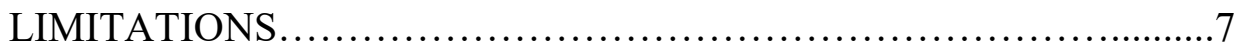

DEFINITION OF KEY TERMS................................ 9

CHAPTER 2-LITERATURE REVIEW $\ldots \ldots \ldots \ldots \ldots \ldots \ldots \ldots \ldots \ldots \ldots \ldots \ldots \ldots$

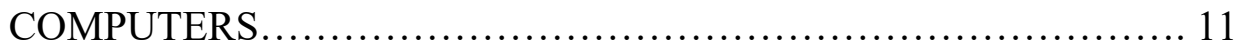

TELECOMMUNICATION AND MULTIMEDIA................... 16

INTERNET ................................................. 17

DIGITAL TECHNOLOGY ........................................19

RELATED RESEARCH........................................20

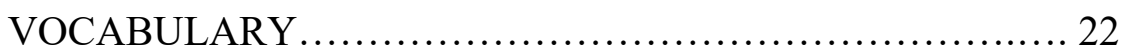

GRAMMAR, WRITING, AND MENTAL -PROCESS.........24

CHAPTER 3-METHODOLOGY ............................................. 30 
RESEARCH QUESTIONS...................................... 31

HYPOTHESIS ................................................. 32

RESEARCH DESIGN.......................................... 33

DATA COLLECTION PROCEDURES................................34

PARTICIPANTS ................................................. 35

MEASURES....................................................... 35

DATA ANALYSIS ....................................................

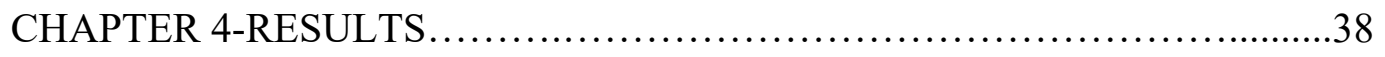

REASEARCH FINDINGS.......................................... 38

DESIGNING AND DELIVERING INSTRUCTION....................39

COMMUNICATION AND COLLABORATION.......................58

PROFESSIONALDEVELOPMENT.................................... 75

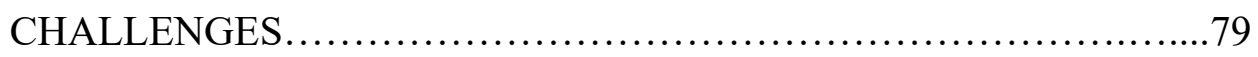

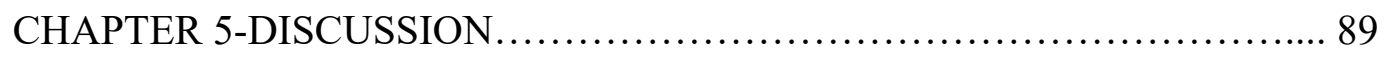

INTRODUCTION...................................................... 89

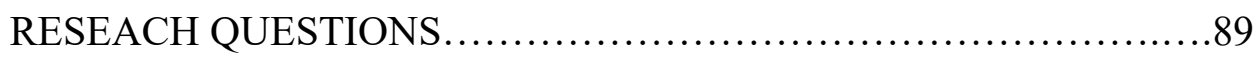

LIMITATIONS.................................................. 108

IMPLICATIONS............................................... 110

CONCLUSION....................................................111

RECOMMENDATIONS FOR FURTHER STUDY ....................113

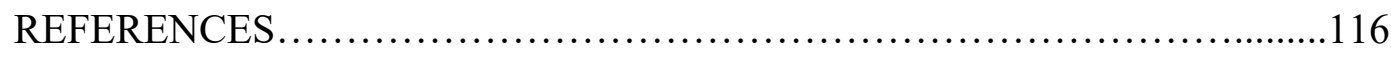

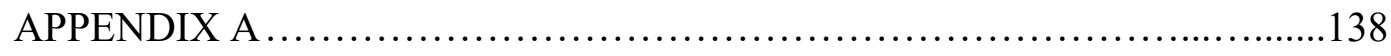


APPENDIX B .......................................................

APPENDIX C 145

\section{LIST OF TABLES}

1. Frequencies with which teachers use technology to design and deliver academic content-based learning activities.......................................40

2. Chi-square analysis for relations between setting in which teacher works and use of technology for design and delivery........................................................42

3. Chi-square analysis for relations between geographic location in which teacher works and use of technology for design and delivery........................46

4. Chi-square analysis for relations between level of students and use of technology for design and delivery ............................................... 50

5. Chi-square analysis examining relationship between use of technology for additional training and use of technology for design and delivery of academic content.............................................................. 55

6. Frequency of using technology for communication and collaboration........... 58

7. Chi-square analysis of relationship between using technology for communication and collaboration and the setting in which the teacher works............... 60

8. Chi-square analysis of relationship between using technology for communication and collaboration and the geographic location of the teacher................64

9. Chi-square analysis of relationship between using technology for communication and collaboration and the level of students taught. 68

10. Chi square analysis of relationship between use of technology for additional training and use of technology for collaboration and communication..........73

11. Chi-square analysis of relationship between use of technology for additional training and setting in which teacher works............................ 76

12. Chi-square analysis of relationship between use of technology for additional training and geographic environment. ...

13. Chi-square analysis of relationship between use of technology for additional training and level of students taught..................................... 77

14. Correlations between use of technology frequency of employer-provided professional development in the use of instructional technology................77

15. Frequency of challenges faced by teachers of deaf $/$ hh students.................79

16. Chi-square analysis of relationship between frequency of challenges faced and setting in which teacher works....................................... 81

17. Chi-square analysis of relationship between frequency of challenges faced and environment in which teacher works.................................. 84

18. Chi-square analysis of relationship between frequency of challenges faced and level of students taught. 


\section{Chapter One: Introduction}

"One of the most important aspects of technology in education is its ability to level the field of opportunity for students" -John King, U.S. Secretary of Education (Randles, 2016).

In 1983, A Nation at Risk recommended computer science as one of five "new basics" to be included in all high school graduation requirements. This marked the beginning of governmental policy designed to guide and advance the use of high-quality educational technology in K-12 settings. Today, the United States Department of Education, Office of Educational Technology strives to reimagine learning and collaboration, promote improved relationships between teachers and students, diminish the equity and accessibility gaps that currently exist in education, and adapt learning experiences to meet the needs of all learners through the use of technology (Office of Educational Technology, 2018).

Schools in the United States have invested billions of dollars in technology infrastructure, professional development, and technical support over the past three decades (Nagel, 2012). Educators have made great strides in their readiness and ability to use technology to foster learning, collaboration, and development of students' skills as communicators, researchers, and critical consumers of information. Schools are redefining the boundaries of the physical school environment, the school day, and the community within which students participate. However, policymakers, practitioners and the public all recognize much remains to be done (Culp, Honey, \& Mandinach, 2003; Jobs for the Future and the Council of Chief State School Officers, 2015). 
Special education has adopted the use of technology across platforms as a means of promoting communication and access, increasing student motivation, and improving learning and achievement (Easterbrooks, Stephenson, \& Mertens, 2006). Deaf education has not followed the same curriculum trends and advances as those evident in general education (Marschark \& Spencer, 2003, 2010). Many of the features of general curriculum are not empirically established for students with a hearing loss (Cannon, Guardino, Antia, \& Luckner, 2016; Marschark \& Spencer, 2010). This creates difficulties as the education system moves to include deaf and hard-of hearing students in general education (Reed, Antia, Kreimeyer 2008).

As reported in the 38th Annual Report to Congress on the Implementation of the Individuals with Disabilities Act (2004) in 2016, 87.3\% of students with hearing loss ages 6-21 were educated in general education classroom with hearing peers for some portion of the day. These students with hearing loss included in general education classrooms struggle with a variety of factors that impact learning. In addition to the hearing loss, these students often come to school with limited access to language, have few quality language models, and tend to have limited life experience as compared to their hearing peers (Adamo-Villani, Carpenter \& Arns, 2006). The general education curriculum does not provide for these limitations (Rude, Jackson, Correa, Luckner, Muir, \& Ferrell, 2005).

Historically, students with hearing loss were educated in self-contained classrooms, resource rooms or in schools for the deaf with teachers of the deaf. Such students in the general education curriculum are typically now limited to consultation services from an itinerant or resource room teacher of the deaf and no longer have access 
to the same level of specialized instructional strategies and supports (Stinson \& Anita, 1999). Technologies allow better access to the curriculum and present the potential to build the needed vocabulary and literacy skills for increased comprehension and communication for students with hearing loss. Additionally, it can provide support for conceptual understanding. The use of such technologies could prove to be a critical element for those students with hearing loss in the general education setting who no longer have access to the daily support of a teacher of the deaf as they would have in a self-contained classroom or school for the deaf (Stinson \& Kluwin, 2011).

\section{History}

Over the years a wide range of technology, from assistive listening devices (ALD) to the more recent augmentative reality applications, has affected the education of deaf and hard-of-hearing $(\mathrm{d} / \mathrm{hh})$ students. Beginning as far back as the $17-18^{\text {th }}$ century, individuals were attempting to use assistive technology in the form of ear trumpets to improve access to spoken language and environmental sounds (Berger, 1988). Since that time, a variety of personal assistive listening devices (e.g. personal hearing aids, bone conduction hearing aids, auditory brain stem implants, and cochlear implants) have been developed for use by individuals with hearing loss. Other technology promoting access and independence became widely available during the 1960's and 1970's. Amplified telephones, vibrating alarm clocks, teletypewriters (TTY), a variety of other alert devices, and the first frequency modulation (FM) system, became available to people with hearing loss during this time (Holmes, Kaplan, \& Saxon, 2000; Kuk, 1992).

It was not until the 1980's and 1990's that technology used for instruction, began to make its way into the classroom. During this period, desktop computers, e-mail, digital 
cameras, fax machines, Microsoft Office Suite and similar software to store, transmit, retrieve, and manipulate information, and the World Wide Web became tools widely available to teachers (Firmin \& Genesi, 2013). Surveys conducted by Deninger (1985), Harding, and Tiball (1982) and Rose and Waldren (1984) demonstrated a steady increase in the use of computers in programs serving $\mathrm{d} / \mathrm{hh}$ students.

This shift in the focus of technology use for instruction ushered in a new era in text, graphics, and video allowed teachers of students with hearing loss to enhance learning and communication with multimedia activities and multifaceted evaluation practices. Teachers of $\mathrm{d} / \mathrm{hh}$ students began using this new technology to increase student exposure to new concepts, critical thinking and communication skills (Harkins, Loeterman, Lam, \& Korres 1996).

In 1992, the National Symposium on Educational Applications in Technology for Deaf Students served as a platform for presentations and formal discussions to identify a set of national priorities for the use of technology with $\mathrm{d} / \mathrm{hh}$ students (Roberson, 2001). These priorities were used to guide teacher preparation programs, enhance public school programs for $\mathrm{d} / \mathrm{hh}$ students, and increase funding for technology integration. Despite the increased availability of technology, many programs reported the need for more space, equipment, supporting materials, staff training, and technical support (Harkin, Loeterman, Lam, \& Korres, 1996).

\section{Technology of Today}

The classrooms of today are significantly different from those of a few decades ago. In addition to whiteboards, laptops, educational websites and online collaborative tools, students often have their own technology (smartphones, tablets, and wearable 
technology) with which many have been familiar with since they were toddlers. This prevalence and mobility provide students access throughout the day and across settings (Maldonado, 2009; Paul 2013).

Another critical change is in technology use is the speed and fashion in which students access information. Educational media is primarily digital, and computer based, available on DVD or streamed online. In addition to the ubiquitous search engines of today (Google, Microsoft Explorer, Safari), most library catalogs, journal collections and books holdings also are available online (Jaeger, Thompson, \& Lazar, 2012).

Students of today are thought to be "digital natives," unable to imagine life without smartphones, tablets, personal computers or social media (Margaryan, Littlejohn, \& Vojt, 2011; Frampton, 2014), while teachers struggle to keep up with the everchanging technology and demands placed on them to meet the growing diversity of students, broad content, rigorous standards for student achievement and high-stakes testing.

\section{Statement of the Problem}

While prior surveys have explored the use of technology for instruction in deaf education, three significant factors make this survey relevant at this time: the movement to include $\mathrm{d} / \mathrm{hh}$ students in general education classrooms, the rate at which technology is advancing, and the increasing availability of technology to both students and school personnel. This survey examined the current use and challenges of existing technology, as well as emerging technology, for the education of students with hearing loss in the areas of communication, collaboration, and instruction. The frequency and types of technology currently used by teachers of $\mathrm{d} / \mathrm{hh}$ students for instruction and to promote 
communication and collaboration for learning were examined across variables. The following research questions guided this study.

Research question 1. What types of technology do teachers of $\mathrm{d} / \mathrm{hh}$ students use to design and deliver academic content-based learning activities? With what frequency, are these technologies being used by teachers of $\mathrm{d} / \mathrm{hh}$ students?

Research question 1a. Is there a relationship between the self-reported amount and/or types of technology used by teachers of $\mathrm{d} / \mathrm{hh}$ students to design and deliver academic content-based learning activities and their job position?

Research question 1b. Is there a relationship between the self-reported amount and/or types of technology used by teachers of $\mathrm{d} / \mathrm{hh}$ students to design and deliver academic content-based learning activities and their use of technology for obtaining additional training?

Research question 2. What types of technology do teachers of $d /$ hh students use to promote student communication and collaboration for learning? With what frequency, are these technologies being used by teachers of $\mathrm{d} / \mathrm{hh}$ students?

Research question 2a. Is there a relationship between the self-reported amount and/or types of technology used by teachers of $\mathrm{d} / \mathrm{hh}$ students to promote student communication and collaboration for learning and their job position?

Research question $\mathbf{2 b}$. Is there a relationship between the self-reported amount and/or kinds of technology used by teachers of $\mathrm{d} / \mathrm{hh}$ students for student communication and collaboration and their use of technology for obtaining additional training? 
Research question 3. Is there a relationship between the self-reported use of technology by teachers of $\mathrm{d} / \mathrm{hh}$ students for additional training and their job position?

Research question 3a. Is there a relationship between the self-reported use of technology by teachers of $\mathrm{d} / \mathrm{hh}$ students for additional training and how often their employer provides professional development in the use of instructional technology for use with deaf/hard-of-hearing students?

Research question 4. Is there relationship between the self-reported amount and/or kinds of challenges experienced by teachers of $\mathrm{d} / \mathrm{hh}$ students and their job position?

\section{Significance}

The significance of this research is two-fold. First, with the rapid rate of technology advancement and availability there is a need to investigate the prevalence of technology use and types of technology being used by teachers of $\mathrm{d} / \mathrm{hh}$ students to better inform preservice and program supervisors. Second, the study illuminates the current needs and challenges associated with using technology in primary and secondary education with $\mathrm{d} / \mathrm{hh}$ students.

\section{Limitations}

The findings of this study were limited in several ways. First, the small sample size and specific characteristics of the sample limited the degree to which the findings will generalize. A second limitation was that the method of data collection was participant self-reporting. Therefore, rigorous experimental control was not possible and self-reporting may have introduced threats to validity. Additional limitations may include 
those specific to data collected through an online survey method (e.g. coverage error, sampling error, nonresponse error, measurement error).

\section{Delimitations}

In an effort to secure a representative sample of participants and avoid a coverage error, the survey was initially disseminated via a secure link in an e-mail invitation to teachers in a range of geographic and socioeconomic areas across the United States. The initial sample included various service delivery models (e.g. schools for the deaf, resource rooms in the general education setting, itinerant) as well as professional organizations. Participants were encouraged to share the survey with other certified teachers of $\mathrm{d} / \mathrm{hh}$ students to increase the sample size. The survey was designed to be anonymous in an effort to encourage truthful answers from participants and decrease any chances of expectancy bias.

To address issues of sampling error and nonresponse error, the survey was designed to be easily accessed online, via an embedding survey link. It was designed to be short and easy to complete with many examples of the types of technology in question. 


\section{Definition of Key Terms}

deaf

deaf refers to a level of hearing loss that is so severe that the child is impaired in processing linguistic information through audition, with or without amplification that adversely affects a child's educational performance. (U.S. Department of Education, IDEA, 2004).

Deaf Deaf refers to individual with a hearing loss who identifies with Deaf culture as defined as a group of people who are deaf and who have their own language (ASL), values, rules, and traditions (Kannapel, 1989).

Hard-of-Hearing For the purpose of this study, hard of hearing will refer to an level of hearing, whether permanent or fluctuating, that adversely affects a child's educational performance but that is not included under the definition of deaf. (U.S. Department of Education, IDEA, 2004).

Technology to Design Technology that facilitates student attainment of learning and Deliver Instruction through multimedia, online tools, and emerging technologies.

Technology for For the purpose of this study, technology for communication Communication and and collaboration will not include personal hearing Collaboration technology (e.g. personal hearing aids, cochlear implants, FM systems). Instead, it will include synchronous and 
asynchronous digital and online collaboration tools, translation applications, video relay systems, social media platforms etc.

Communication $\quad$ For the purpose of this study, communication refers to an exchange between teachers, student and teacher, or student and peer for the purpose of imparting or exchanging information.

Collaboration

For the purpose of this study, collaboration refers to the act of teachers and/or students working together to create a produce or achieve a goal.

Virtual Assistant

For the purpose of this study, virtual assistant refers to a software agent in digital form that can perform tasks or services for an individual.

\section{Summary}

Including students with hearing loss in the general education setting requires educators who understand and can adapt instruction, communication and support to meet the needs of the individual student. The data collected during this study will advance knowledge of the various technology used by teachers of $d / h$ h students for communication, access, and instruction in the United States, as well as inform future preservice preparation and ongoing professional development to better prepare teachers to meet the diverse needs of this population. 


\section{Chapter Two: Literature Review}

This chapter will provide a review of the literature as it pertains to the use of technology by teachers of deaf and hard-of-hearing $(\mathrm{d} / \mathrm{hh})$ students. The literature review was conducted in two forms: exploratory and systematic. An exhaustive review of the research literature published from 1980 through 2017 was carried out to explore previous surveys of technology use by teachers of $d / h h$ students. Survey research is one of the most widely used research methods in deaf education because it allows for a large-scale collection of data across a population with vastly diverse demographic characteristics, heterogeneity of the learning characteristics and contexts (Jones, 1984; Shaver, Marschark, Newman, \& Marder, 2013). A systematic review was then completed to locate related research that reports technology use for designing and delivering instruction to $\mathrm{d} / \mathrm{hh}$ students. Beginning with the survey research, the literature review will progress chronologically with the very first published surveys of technology use by teachers of $\mathrm{d} / \mathrm{hh}$ students in the 1980 s and, reviewing the published research pertaining to technology use by $\mathrm{d} / \mathrm{hh}$ hearing students the areas of computers, telecommunication and multimedia, the Internet, and digital technology.

\section{Computers}

In the field of education, very few innovations have affected change in all areas of education on par with technology. The use of technology as reported in the literature in deaf education follows the historical timeline of available technology. The mid 1970s

introduced the Apple II series computers and computer-based instruction was born. While the integration of technology in special education predates the invention of the microcomputer, it was not until the 1980s that research on the impact of technology 
became available in the literature (Jeffs, Morrison, Messenheimer, Rizza, \& Banister, 2003). Beginning in the 1980s, surveys were conducted to determine how many and in what capacity computers were used in programs serving d/hh students (Deninger, 1985; Rose \& Waldron, 1984; Harding \& Tidball, 1982). These surveys examined the availability of computers and their applications in programs for $\mathrm{d} / \mathrm{hh}$ students. The results of these initial studies documented a progressive increase in the percentage of programs that used computers for instruction.

In “A National Microcomputer Software Survey of Current Microcomputer Usage in Schools for the Hearing Impaired," Harding and Tidball (1982) collected data from 120 schools for $\mathrm{d} / \mathrm{hh}$ students representing 45 states. The research method consisted of a direct mail survey with 14 open-ended questions concerning the use and challenges of microcomputers. The results indicated that of the $42 \%$ of schools using microcomputers, they were being used for instruction $62 \%$ of the time. The number of microcomputers ranged from 1 to 50, with Apple computers being the model used by most schools. Of the schools that responded, 34 schools had 5 or less microcomputers. The small sample size $(\mathrm{N}=120)$ and specific characteristics of the sample (day and schools for the deaf for the deaf) limit the degree to which the findings were able to be generalized. Additionally, the method of data collection required participants to self-report. This created a situation where rigorous experimental control was not possible. Nonetheless, this study was the first to establish what would be a trend in some of the major barriers to using technology with this population: financial support, teacher training, lack of available hardware and/or software. 
Two years later, Rose and Waldron (1984), conducted a national survey by mailing 342 questionnaires to those programs for $\mathrm{d} / \mathrm{hh}$ students listed in Part II Educational Programs and Services of the American Annals of the Deaf (1983). A return of 224 completed surveys were representative of $65 \%$ of the public and private residential programs, resource rooms, and $\mathrm{d} / \mathrm{hh}$ classrooms in public school buildings. Data analyses included descriptive statistics and frequency distributions by program characteristics. Results indicated that in 115 programs there were a total of 979 microcomputers being used. Again, the number of computers per program ranged from 1-50 with a mean of 8 . Apple computers represented $66 \%$ of the equipment used but were concentrated in $17 \%$ of all the programs surveyed; whereas IBM personal computers were distributed across $27 \%$ and Radio Shack's TRS- 80 across $16 \%$ of the $\mathrm{d} / \mathrm{hh}$ programs. The results indicate a $10 \%$ increase in the number of $\mathrm{d} / \mathrm{hh}$ programs using microcomputers in the classroom from the results gathered by Harding and Tidball in1982. Fifty percent of the programs reported that training occurred in the form of local school in-service. Programs identified needs included more appropriate in-service training from university or formal in-service opportunities, instructional software, consultation, research, support, and continued advancements in instructional media.

In 1985, Michael Deninger mailed out a one-page survey to 500 schools for the deaf for the deaf, day schools and public day classes for the deaf. The research questions were designed to expand upon the current knowledge by again establishing how many, and what types of computers were being used with $\mathrm{d} / \mathrm{hh}$ students, and also what software was being used, if the programs had a budget for hardware and/or software, and who was responsible for the use of computers at each school. A total of 310 surveys were returned. 
This represented $60 \%$ of the total number of $\mathrm{d} / \mathrm{hh}$ programs surveyed. Of the surveys returned, $241(70 \%)$ reported having at least one computer. At this point in time, residential programs reported a much higher use of microcomputers $(96 \%)$, than the day schools $(76 \%)$ or the day classes $(73 \%)$. Apple computers continued to be the dominant model used by $87 \%$ of the $\mathrm{d} / \mathrm{hh}$ programs surveyed. As with use, schools for the deaf also reported larger operating budgets for hardware and software purchasing during the 19831984 school year. Another important finding of this study was that although computer use was growing and schools were starting to allocate monies for computer equipment, not enough emphasis was placed on software purchasing to fully implement the hardware as desired (Deninger, 1985).

These three studies demonstrated a consistent growth in the use of technology for instruction this $\mathrm{d} / \mathrm{hh}$ students.. The results of the study completed by Harding and Tidball (1982) showed that $42 \%$ of the schools surveyed had computers being used for instruction while Rose and Waldron (1984) showed 52\% of the programs surveyed had computers being used for instruction and Deninger's research (1985), just a year later, showed $79 \%$ of responding programs to have at least one computer. In a comparison with data from Quality Education Data, Inc. (QED), of Denver, Colorado, Deninger (1985) found that the growth of computer technology in $\mathrm{d} / \mathrm{hh}$ programs commiserate with those of general education programs.

Despite the increasing availability of computers during this time, training in the foundational use of computers and computer applications was provided in fewer than $20 \%$ of deaf education teacher preparation programs (Israelite \& Hammermeister, 1986). Underscored by Fahy's (1985) finding that the primary factors affecting adoption of 
instructional innovations, specifically computer-based instruction, are attitudinally based, researchers, Mertens and Wang (1988), conducted an empirical study which examined the attitudes of 43 preservice teachers of students with hearing loss towards computers. The sample was comprised of graduate students (20) and undergraduate students (23) enrolled in deaf education programs. Demographic information was obtained for each of the participants after which, each completed the Computer Attitude Scale (Lloyd \& Gressard, 1984). The researchers hypothesized that computer experience leads to more positive attitudes toward computers. The resulting descriptive statistics indicated that older women with more computer experience appeared to express more positive attitudes towards computer use. The over-all results of the study confirmed that computer experience was found to be a major factor in computer confidence. This would suggest that exposure to computers and training in the effective use and integration of technology is a beneficial component of teacher preparation programs and professional development plans.

In 1992, the National Symposium on Educational Applications of Technology for Deaf Students hosted various formal discussions, presentations, and professional forums to identify nationally recognized priorities for the use of technology with $\mathrm{d} / \mathrm{hh}$ students (Stuckless \& Carroll, 1994). The resulting twenty-one priorities would then be used to guide the development and improvement of teacher preparation programs, enhance public school programs serving $\mathrm{d} / \mathrm{hh}$ students, and increase local, state, and federal support for the integration of technology into the education of deaf and hard-of-hearing students. The mid-1990's proved to be an exciting time for deaf education as visual communication and multimedia instructional tools shifted the way information was presented to students. 


\section{Telecommunication and Multimedia}

Between 1994 and 1996, the professional literature supported the use of various forms of technology with $\mathrm{d} / \mathrm{hh}$ individuals. Technology had begun to change the world for deaf and hard-of-hearing people by making communication more visual. The use of fax machines, pagers, electronic mail, and online services in conjunction with the federal mandate for nationwide telephone relay services greatly increased access and selfefficacy for people with hearing loss (Harkins, 1994).

Harkins (1994) asserted that visual telecommunications "can empower them (d/hh individuals) to take initiative at earlier ages than has previously been possible" (pp. 195196). Per Harkins, the advent of visual communication and related technologies during this time would prove to increase $\mathrm{d} / \mathrm{hh}$ students' motivation to read and write as well as interact socially with family members and peers. Harkins also stated that the lack of access to technology and qualified staff to train the students in the use of the technology would hinder these potential advancements. She asserted that "schools need assistance to update curriculum, technology, and staff skills to meet the new challenges of preparing children for lives as deaf and hard-of-hearing adults" (p. 196). This would continue to be a trend as education and technology began to merge.

Harkins, Loeterman, Lam, and Korres (1996) conducted a national survey on the availability of technology for instruction. This survey yielded a sample response from over 500 programs serving $\mathrm{d} / \mathrm{hh}$ students nationwide. The percentage of programs having at least one computer available for instruction was reported to be $96 \%$ as compared to $79 \%$ reported by Deninger in 1985 . The research confirmed that multimedia equipment such as VCRs (99\%) and camcorders (82\%) were prevalent, but greater than half the 
schools inventoried reported no newer types of equipment such as LANs, modems, fax machines, video disc players, TV's with built in decoders, satellite dishes, or captioning systems for instruction. Forty-two percent of schools had ten or fewer computers available for instruction.

As more technology became available, challenges related to acquisition, training, and anxiety were reported (Harkins, et al, 1996). Edward Corbett and Pamela Micheaux (1996), devised a questionnaire with 40 questions focused on the following issues related to technology: planning for technology, networking, curriculum and instruction strategies, financing, and technology policy. In this study, the researchers contacted six schools for the deaf for deaf and hard-of-hearing students. Three schools $(50 \%)$ responded to the questionnaire. Published responses to the questions posed, support the findings of Harkins, et al, (1996) that $\mathrm{d} / \mathrm{hh}$ centers and residential school programs were committed to integrating technology into the curriculum, planning for future uses of technology, and placing a priority on the financing of computers at a pace greater than the

local general education schools. Responses to the Corbett and Micheaux (1996) questionnaire indicated that $\mathrm{d} / \mathrm{hh}$ programs were struggling with the constant growth of technology both in terms of technology acquisition, and training, support, and connectivity. Incorporating technology use across curriculum would become increasingly feasible with the increased access to information, tools, and resources that the internet would provide.

\section{Internet}

In 1994 the World Wide Web was born, and with it, access to a plethora of information and additional communication capabilities. In 1997, Clymer and McKee 
summarize information from a national survey that collected information on instructional technology resources available at two hundred and two schools serving $\mathrm{d} / \mathrm{hh}$ students on the availability of instructional technology. Seventy percent of the K-12 programs reported having access to e-mail and the internet indicating that most of these programs could feasibly use the internet on a regular basis for instruction. In reviewing these survey results, the authors highlighted two critical factors in making effective use of technology for instruction and differentiation: access to technology and the successful incorporation of technology in the classroom (Clymer \& McKee, 1997).

In a study completed in 1999, Pillai investigated the use of instructional technology by certified primary and secondary teachers of $\mathrm{d} / \mathrm{hh}$ students in rural Alaska. The direct-mail survey focused on the relationship between teacher variables and technology use for instruction. This differed from previous research focused on the amount or kinds of technology being used. The data yielded a positive correlation $(\mathrm{p}<$ .05 ) for educators who reported using instructional technology for direct or related curriculum instruction and the following variables: age (older), education (held secondary certification), and having internet access. Also, these educators benefited from some form of technology training. Seventeen barriers to technology use were identified. These barriers included lack of adequate hardware, lack of adequate software, and lack of educator input regarding technology adopted by the school district. Based on the data, Pillai (1999) made nine recommendations to increase technology use in those rural Alaskan districts. These recommendations included specialized training, training within the curricular context, improved internet access, modeling, and mentoring. Fortunately, advances in digital technology including mobile technology and collaborative tools 
would make recommendations like these possible across increasingly more locations and academic levels.

\section{Digital Technology}

The final decades of the $20^{\text {th }}$ century brought forth the rapidly evolving information technology revolution. Global networking and digital technology made computers smaller, more affordable, and mobile. Words like iPod, iPad, iPhone, apps., Google, Facebook, and Twitter were added to the common lexicon of both students and teachers. In 2001, Len Roberson analyzed how preservice programs for teachers of $\mathrm{d} / \mathrm{hh}$ students used, modeled, and taught the integration of computers and related technology. Researchers sent direct mail surveys to faculty and administrators of preservice programs for teachers of $\mathrm{d} / \mathrm{hh}$ students. Despite having a low return rate $(30 \%)$, the faculty surveys were geographically representative of all four geographic regions in the United States. Participants were asked to indicate the importance of twenty competencies on a Likertlike scale of 1 (Not Important) to 5 (Extremely Important). Although ninety-five percent of the competencies were rated either important or very important by faculty and eightyfive percent by administrators, only six of the twenty competencies were reported to be modeled in the courses by the respondents. The use of computer-related terminology was the most frequently $(70 \%)$ modeled competency, with word-processing $(61 \%)$ being the second most often modeled competency of the faculty. Challenges or barriers to the effective integration of technology in this study support those of previous research (Mertens \& Wang, 1988; Pillai, 1999). Financial resources for new equipment, lack of training, modeling, and adequate time to learn new technology were all listed as obstacles to integrating technology. 
In 2005, Kluwin and Nortetsky conducted a study of 47 teachers of d/hh students in the United States as they completed an online course designed to promote technology integration into their teaching. The objective of this study was to identify factors that supported the success of technology integration in the program. The results suggested that the integration of technology is multi-layered and occurs throughout the learning process. Teachers with less experience struggled with basic skills and cited challenges in the actual use of technology while the participants who were more proficient in the use of technology were challenged by how to best integrate it into instruction.

Using a combination of survey data, retention data, and course discussion information, the researchers concluded that, in combination with a local support person, it is possible to improve the technology skills of teachers of $\mathrm{d} / \mathrm{hh}$ students using remote instruction, with a highly responsive instructor. However, a combination of factors (e.g. reducing anxiety, providing technical support, and matching the technology to the instructional setting and objectives) constituted success among participants. While factors such as limited coursework in technology use, limited professional development in technology, and the advanced speed of technological development, led to educators who were limited in their ability to understand, utilize, and fully integrate the technologies that were available. Despite challenges, technology was being embraced by teachers of $\mathrm{d} / \mathrm{hh}$ students to further support language acquisition, provide multi-modal and experiential learning opportunities, and support a variety of academic skills in the classroom.

\section{Related Research}

During these final decades of the $20^{\text {th }}$ century and beginning $21^{\text {st }}$ century there was a significant body of research that focused largely on technology interventions in the 
education of deaf and hard-of-hearing $(\mathrm{d} / \mathrm{hh})$ students. The literature can be divided into four separate categories based on the type of technology intervention: computer-based software, virtual reality, captioning programs, and sign language materials. The primary academic skills addressed, in various combinations within this research base included: reading and/or lecture comprehension, math comprehension and application, vocabulary acquisition, and grammatical skills, writing skills, and mental processes.

A substantial amount of the research reviewed focused on improving comprehension. The interventions used were computer-based applications, captioning, or a combination. Students with hearing loss tended to comprehend lecture material better when provided with captions and other visual cues as opposed to when the lectures were presented only verbally (Anderson-Inman, Terrazas-Arellanes, \& Slabin, 2009; Cambra, Silvestre, \& Leal, 2008/2009; Lewis \& Jackson, 2001; Szarkowska et al., 2011; Ward et al., 2007). These findings align with those studies focused on comprehension for reading and mathematics. Students with hearing loss seemed to benefit the most when a combination of print and visual representations such as pictures or photos were used (Gentry et.al., 2004/2005; Mich, Pianta, \& Mana, 2013) or when captions were paired with an American Sign Language (ASL) video (Mich et al., 2013; Parton, 2011;Wang \& Paul, 2011; Parton, 2008) to present instructional material. Student engagement and performance were greatly improved when instruction was paired with scaffolding software (Liu, Chou, Lui, \& Yang, 2006).

When using interactive 3D virtual reality technology, students made the most gains in sequencing of story elements in both reading and mathematics when using multimedia and interactive applications (Mich, Pianta, \& Mana, 2013; Passig \& Eden, 
$2000 \mathrm{~b}$ ) as opposed to 2D shapes or materials that were not animated and therefore, less interactive. Digital animation has been found to increase student's vocabulary and critical thinking. Animated avatars that provide models for a variety of language and speech related skills have been found to successfully increase vocabulary and speech production (Adamo-Villani \& Anasingaraju, 2017; Barker, 2003; Jaballah, \& Jemni, 2013; Massaro \& Light, 2004). A cornerstone of reading comprehension is vocabulary acquisition; therefore, a large body of research has focused on strategies to improve vocabulary and related literacy skills.

Vocabulary. Most vocabulary acquired by hearing students is from indirect encounters with the words through daily interactions and environmental exposure (Hart \& Risley, 2003). Students learn new words from interactions with adults and peers, as well as with literacy and media in the environment. Initially, it is through these informal encounters that children acquire basic interpersonal communication skills (BICS) such as vocabulary, grammar, rules of language usage, whereas formal schooling promotes the development of cognitive academic language proficiency (CALP) such as language for learning and the skills required for formal education such as reading, writing, and reasoning. Children who grow up with a hearing loss are at a disadvantage as they come to the school environment with significantly lower vocabulary and related language skills in BICS and as a result, a delay in acquiring the CALP skills that are paramount for learning (Mayer, Akamatsu, Marschark, \& Spencer, 2011).

Deaf and hard-of-hearing students miss much of this critical incidental learning and thus have more limited exposure to new vocabulary, as well as limited opportunities to use new vocabulary (Goldin-Meadow \& Mylander, 1990; Goldin-Meadow, 1999). 
While it is well documented that $\mathrm{d} / \mathrm{hh}$ students are significantly behind their hearing peers in vocabulary acquisition (Marschark, Nagel, Shaver, \& Newman, 2015; Sarchet, Marschark, Borgna, Convertino, Sapere, \& Dirmyer, 2014), and that this vocabulary development is key in developing literacy skills (Spencer \& Marschark, 2010), there is very little empirical research to support best practice for vocabulary acquisition for deaf and hard-of-hearing students (Beal-Alvarez \& Cannon, 2014; Schirmer \& McGough, 2005).

In a review of the literature, multiple studies were found that used computerbased multimedia applications for instruction with learners with hearing loss. (Barker 2003, Cannon, Easterbrooks, Gagne \& Beal-Alverez, 2011; Gentry, Chinn, \& Moulton, 2004/2005; Lang \& Steely, 2003; Mich, Pianta, \& Mana, 2013; Passig, \& Eden, 2010; Reitsma, 2009; Stoner, Easterbrooks \& Laughton, 2005; Vesel, 2006; Vesel \& Robillard, 2013; Wang \& Paul, 2011). Researchers Jackson, Gaudet, McDaniel and Brammer (2009) stated that the use of multimedia technology, including synchronous text-talking media can enhance learning and promote the acquisition of information at all levels through multiple modalities and immediate feedback. This use of technology could therefore accommodate diverse styles of learning and allow instructors to structure educational activities to enable effective interaction, communication, and higher-level thinking.

Multimedia computer programs, applications and digital media present a combination of both verbal and visual information, including pictures, video, and models such as concept maps to introduce new vocabulary and grammatical concepts. These types of programs have proven to increase recall, and retention of information over 
information presented in only one form (Paivio, 2006; Parton 2006). Hamilton (2012) conducted a study titled, "The Efficacy of Dictionary Use while Reading for Learning New Words," which suggested that $\mathrm{d} / \mathrm{hh}$ students may benefit from the use of electronic bilingual multimedia English-ASL dictionaries to build vocabulary during independent reading.

Emerging research in the use of augmentative reality (AR) and virtual reality (VR) advocates the use of this technology to provide individuals with sensory disabilities in an immersive experience that supports multisensory learning environments (Brown \& Green, 2012; Clemens et al. 2013; Latif, 2012; Powers \& Darrow, 1994; Smith, 2013; Smith \& Brown 2011). Preliminary research suggested that the use of virtual reality could potentially improve vocabulary, concept understanding, and academic progress in math and science via the use of a multimedia application using a virtual reality avatar in combination with text and visuals to access math, science and related vocabulary (Vesel, 2006; Vesel \& Robillard, 2013). Instructional technology can be used to develop and provide practice of vocabulary knowledge for both native and second-language learners (Druin \& Hendler, 2000) as well as individuals with special needs (Adamo-Villani \& Wright, 2007; Adamo- Villani, 2006; Barker, 2003).

This line of research reported increased motivation and engagement of $\mathrm{d} / \mathrm{hh}$ students (Cannon, Fredrick, \& Easterbrooks, 2010; Cannon Easterbrooks, Gagné, \& Beal-Alverez, 2011; Nikolaraizi \& Vekiri, 2011). Subsequent skills needed for improved literacy such as grammar, writing, and mental process were also explored during this period. The critical thinking skills needed to understand text and required writing skills to effectively communicate also became a focus. 
Grammar, writing and mental process. Other research of this decade demonstrated the use of technology to improve writing and thinking skills for $\mathrm{d} / \mathrm{hh}$ students. The use of word processing software has been shown to improve the length, complexity and use of varied vocabulary (Strassman \& O’Dell, 2012; Stoner, Easterbrooks, \& Laughton, 2005). Donne (2013) found that multiple studies supported the use of multimedia to support understanding of texts and increased written engagement. Critical thinking skills such as the ability to make inferences and predictions showed improvement after students engaged in 3D virtual reality puzzle games involving object rotation (Passig \& Eden, 2000a). Increased motivation to attend to and complete academic tasks was also documented in studies with deaf and hard-of-hearing students during this time (Cannon, Easterbrooks, Gagne, \& Beal-Alverez, 2011; Chen-Chung Liu, Chien-Chia Chou, Baw-Jhlune Liu, \& Jui-Wen Yang, 2006).

Despite the prevalent use of technology in the education of $\mathrm{d} / \mathrm{hh}$ students, and its documented positive effect on learning during this time, Beal-Alverez and Cannon (2014) discovered that none of the research on technology intervention with $\mathrm{d} / \mathrm{hh}$ students met all the established criteria set forth by the What Works Clearinghouse (Institute of Educational Sciences [IES], 2011, 2013) for evidence-based research intervention for all students. The authors evaluated 29 peer-reviewed, technology-based interventions that focused on improving academic outcomes of $\mathrm{d} / \mathrm{hh}$ students from preschool to college published from January 2000-August 2013 and concluded that the field of deaf education lacks a body of evidence in support of any instructional practice as defined by the WWC with the indicators proposed by IES for $\mathrm{d} / \mathrm{hh}$ students (Easterbrooks, Stephenson, \& Mertens, 2006; Luckner, Sebold, Cooney, Young, \& Muir, 2005/2006). 
Beal-Alverez and Cannon (2014) selected this specific timeframe based on the “accelerating pace of technological innovation and the introduction of new technology on the classroom" (p. 487). Due to the low incidence of hearing loss, the research methodologies commonly used in deaf education research included experimental group design and single case design. Neither of these types of research meet the (IES, 2011) established "gold standard" of research evidence for education practice which is defined as randomized, controlled trials. The methods are neither randomized controlled trials, nor are they typically completed with a large, diverse sample that is representative of the population. Limitations in the Beal-Alverez and Cannon study included limited search results based on the specific search terms used, the review of exclusively peer-reviewed publications for the sample, and the absence of any studies completed on students younger than preschool age.

The results of the Beal-Alverez and Cannon study indicated that despite many technologies being developed during this time, few of those examined were identified as being used in intervention-based instruction. Beal-Alverez and Cannon (2014) suggested that researchers and educators might focus on the instructional presentation format as it relates to meeting student needs and then adhering to the proposed quality indicators, replicating these studies to increase the rigor and replication of effective interventions to increase the positive academic outcomes of $\mathrm{d} / \mathrm{hh}$ students.

The applications of technology are far reaching and are present across a broad range of purposes and professions in today's world. All learners in the $21^{\text {st }}$ century classroom are expected to collaborate, think critically, problem solve, and synthesize a variety of information while utilizing rapidly evolving digital technologies. Therefore, it 
is important to examine how teachers of $\mathrm{d} / \mathrm{hh}$ students incorporate technology into the classroom to enhance the learning experience of all students and familiarize them with technology necessary to compete and thrive in a job market rich in technology (Mishra, Koehler, \& Henriksen, 2011, Herold, 2016).

According to the U.S. Bureau of Labor Statistics, more than $50 \%$ of today's jobs require some degree of technology skill, and that percentage may increase to more than 70\% by 2020 (Lockard \& Wolf, 2012). Employment in STEM (Science, Technology, Engineering, and/or Math) is expected to grow to 9 million by the year 2020 (Vilorio, 2014). Technology has the potential to provide a variety of educational, employment, and social opportunities (Kaye, 2000). It is therefore important to assess how prevalent and what types of technology are being used by $\mathrm{d} / \mathrm{hh}$ individuals. To determine the various technologies used by $\mathrm{d} / \mathrm{hh}$ adults living in the United States, Maiorana-Basas and Pagliaro (2014) designed a survey comprised of 20 questions. The questions addressed the use, frequency, and preference of various technologies by $\mathrm{d} / \mathrm{hh}$ adults across the nation.

The sample was made up of two hundred and seventy-eight participants of varying backgrounds, ages, communication preferences, audiological levels, use of assistive listening devices (ALDs), educational levels, income, and disability other than deafness living in 31 states and the District of Colombia. Findings from this survey suggested that $\mathrm{d} / \mathrm{hh}$ individuals frequently use smartphones such as iPhones, Androids, and Blackberrys $(71.6 \%)$, as well as personal computers (PC) $(70.9 \%)$. There were significant differences by age with the younger participants preferring a smartphone while older individuals had PCs. A majority (62.9\%) of the sample reported using 
technology in the home whereas only $29.1 \%$ reported using technology at work and $4.3 \%$ at school. Approximately $88 \%$ reported using e-mail, while $75.5 \%$ utilized text messaging for communication. Between $40 \%$ and $50 \%$ of participants reported frequent use of technology for video conferencing and document writing. Surfing the Internet was a popular use of technology reported by $74.5 \%$ of the respondents. A majority $(60 \%)$ of the sample reported using research/search engines. Google and related websites were the most popular websites visited (39.3\%). This was followed by the social media website Facebook (32.9\%) and lastly news/ information sites such as CNN (31.3\%). Although web-site design preferences varied by age, presence of a disability, communication preference, and educational level, more than $40 \%$ of participants reported that they wanted captions or captioning options available on websites.

These findings suggest that of the individuals surveyed, a majority of $\mathrm{d} / \mathrm{hh}$ adults utilize technology across multiple platforms for a variety of purposes related to, but not limited to, work, recreation, research, and learning. The students of today are ones born into a world of technology. Few can imagine a world without smartphones, tablets, personal computers or social media (Margaryan, Littlejohn, \& Vojt, 2011; Frampton, 2014). As a result, teachers endeavor to keep up with emerging technology in the classroom and demands placed on them to meet the growing diversity of students, broad content, rigorous standards for student achievement and high-stakes testing.

There are no current data on the various forms of technology used by teachers of $\mathrm{d} / \mathrm{hh}$ students for communication, access, and instruction in the United States. The most recent study to attempt to collect this type of information was the aforementioned research study completed by Pillai (1999), titled, "Using Technology to Educate Deaf and 
Hard-of-hearing Children in Rural Alaskan General Education Settings." The education movement to include students with disabilities, including, $\mathrm{d} / \mathrm{hh}$ students, in general education classrooms, as well as the rapidly advancing and readily available technology in the classroom merits an exploration of the current use and challenges of existing technology as well as emerging technology for communication, collaboration, and instruction with $\mathrm{d} / \mathrm{hh}$ students.

To summarize, deaf education is a field greatly impacted by technology for the purposes of communication and instruction. As more and more students with hearing loss move into general education classrooms, the service delivery model and accommodations must also change to meet the unique and diverse needs of those learners. Technology is one way that teachers can address differentiation across instruction, communication and collaboration, while meeting the demands for formative assessment through software and applications designed to track progress. (Hobsgood \& Ormsby, 2010). Technology provides access to professional learning communities for teachers who can sometimes otherwise be isolated form professional peers in this low incident disability area. The intent of this current survey study is to discover the various types of technology and frequency of use by teachers of $\mathrm{d} / \mathrm{hh}$ students for communication, access, and instruction in the United States. Additionally, results will inform future preservice preparation and the ongoing professional development of the needs and challenges identified by the respondents to better meet the diverse needs of this population. 


\section{Chapter Three: Methodology}

This chapter describes the purpose of the research and outlines the research questions. The research design is defined, with a description of the selection of participants and plan for data collection and analysis.

This study explored the types of technology used by teachers of deaf and hard-ofhearing $(\mathrm{d} / \mathrm{hh})$ students to design and deliver instruction, as well as which types of technology are being used by teachers of $\mathrm{d} / \mathrm{hh}$ students to promote communication and collaboration. It also examined the extent of preparation and professional development in the area of technology use with $\mathrm{d} / \mathrm{hh}$ students, and the related challenges experienced by these teachers.

Survey research is one of the most widely used methods in deaf education because it allows for a large-scale collection of data across a population with vastly diverse demographics as well as a heterogenous mix of the learning characteristics and educational settings (Jones, 1984; Shaver, Marschark, Newman, \& Marder, 2013). As such, a modified version of the online survey "Technology Use Among Adults Who Are Deaf and Hard-of-hearing," (Mairorana-Basas \& Pagliaro, 2014) was created to examine the research questions. The survey was comprised of four multipart questions addressing: (a) use (e.g. frequently, sometimes, rarely, never) and preference of technology to design and deliver content-based learning activities (22 subquestions), (b) use and preference of technology to promote communication and collaboration for learning (22 subquestions), (c) use and preference of additional training or information on technology use for instruction (three questions with seven subquestions), and (d) frequency (e.g. frequently, 
sometimes, rarely, never) and types of challenges in using technology for instruction (twelve subquestions). Eight final questions addressed the demographic information of the participants.

\section{Research Questions}

The research questions that follow, were chosen to guide this dissertation study. Research question one and two provided the overall foundation for the research; the additional questions further refined the focus.

Research question 1. What types of technology do teachers of $\mathrm{d} / \mathrm{hh}$ students use to design and deliver academic content-based learning activities? With what frequency, are these technologies being used by teachers of $\mathrm{d} / \mathrm{hh}$ students?

Research question 1a. Is there a relationship between the self-reported amount and/or types of technology used by teachers of $\mathrm{d} / \mathrm{hh}$ students to design and deliver academic content-based learning activities and their job position?

Research question 1b. Is there a relationship between the self-reported amount and/or types of technology used by teachers of $\mathrm{d} / \mathrm{hh}$ students to design and deliver academic content-based learning activities and their use of technology for obtaining additional training?

Research question 2. What types of technology do teachers of $d /$ hh students use to promote student communication and collaboration for learning? With what frequency, are these technologies being used by teachers of $\mathrm{d} / \mathrm{hh}$ students?

Research question 2a. Is there a relationship between the self-reported amount and/or types of technology used by teachers of $\mathrm{d} / \mathrm{hh}$ students to promote student communication and collaboration for learning and their job position? 
Research question $\mathbf{2 b}$. Is there a relationship between the self-reported amount and/or kinds of technology used by teachers of $\mathrm{d} / \mathrm{hh}$ students for student communication and collaboration and their use of technology for obtaining additional training?

Research question 3. Is there a relationship between the self-reported use of technology by teachers of $\mathrm{d} / \mathrm{hh}$ students for additional training and their job position?

Research question 3a. Is there a relationship between the self-reported use of technology by teachers of $\mathrm{d} / \mathrm{hh}$ students for additional training and how often their employer provides professional development in the use of instructional technology for use with deaf/hard-of-hearing students?

Research question 4. Is there relationship between the self-reported amount and/or kinds of challenges experienced by teachers of $\mathrm{d} / \mathrm{hh}$ students and their job position?

\section{Hypotheses}

The changes in service delivery and placement prompted by enactment of the Individuals with Disabilities Education Act, (IDEA), in 2004, resulted in increasing numbers of students with hearing loss being educated in the general education setting. A review of the literature demonstrates a gap in the research of current teacher use of technology with $\mathrm{d} / \mathrm{hh}$ students. This change in service delivery coupled with the exponential growth and progress of educational technology, merits an examination of current teacher use. This was an exploratory study to examine the influence of both individual level variables and organizational level variables on the frequency and types of 
technology used by teachers of $\mathrm{d} / \mathrm{hh}$ students; it required no formal hypothesis as it was exploratory in nature.

\section{Research Design}

This exploratory study used an electronic survey design. The design allowed the researcher to collect of a large amount of data from across the United States in a short period of time. The survey utilized a 4-point Likert-type scale (Frequently, Sometimes, Rarely, and Never) for the multi-part questions. Eight multiple choice questions requesting demographic information followed. The survey study was cross-sectional in nature and only examined the sample population at this point in time. The population was comprised of a sample of teachers of $\mathrm{d} / \mathrm{hh}$ students with varying levels of education, differing years of experience, differing locations, and a variety of ages. A cross-sectional study compares two or more educational groups of participants at one point in time allowing for a range of responses regarding the practices, experiences, or beliefs of respondents within educational settings (Creswell, 2009).

The survey was conducted online and could be completed at any location where the participant had access to a computer with Internet service. Although the survey was available in a non-digital format, none of the participants requested a paper copy.

The sampling method was a snowball sampling method recruiting initial participants through a letter sent to them via state agency, professional organization or school program (see Appendix A). Those participants were encouraged to share the survey with other potential participants via professional organization, shared employment setting, social networking, etc. 


\section{Data Collection Procedures}

This study utilized a snowball sampling method where the initial participants were recruited through an e-mail sent to various state agencies, professional organizations, and school programs (see Appendix A). The e-mail served as the cover letter and implied consent for the survey. This was documented as such for the Internal Review Board's Exempt, Category 2 status. Recruitment was conducted through state agencies, and professional organizations including the Convention of Instructors of the Deaf (CAID) and Association of College Educators-Deaf and Hard-of-Hearing (ACEDHH). The American Annals of the Deaf, Reference Issue, 2016, provided directory information (names, addresses, and email contact information) for 640 schools and programs in the United States and territories that enroll or provide services to children who are deaf or hard-of-hearing in specialized schools or centers (residential/boarding), charter schools, local programs, or other types of programs serving this population. Each of these programs was contacted with an invitation to all instructors of the programs listed.

The letter of invitation also instructed participants to share the invitation with equally qualified individuals to increase the number of participants. Two follow-up emails were sent reminding the qualified individuals to complete the survey. The survey was disseminated through a secure web link provided by Qualtrics.com. Participants were given two weeks to complete the survey. Data was collected via an online questionnaire including both demographic information and a continuous four-point Likert-type scale in the questionnaire (Frequently, Sometimes, Rarely, and Never) designed to measure four 
distinct variables: technology use for learning, technology for communication and collaboration, challenges in using technology, and training/professional development.

\section{Participants}

Participants consisted of individuals certified to teach students with hearing loss across the United States. Participant education levels ranged from baccalaureate to doctoral degrees, with the largest percentage (47.4\%) at the master's level. Employment settings were reported across urban, suburban, and rural environments (see Appendix C). Three hundred and sixty-nine teachers employed in specialized schools or centers (residential/boarding), charter schools, local programs, or other types of programs serving d/hh students responded to an anonymous survey (see Appendix B) based on a modified version of the "Technology Survey of Deaf and Hard-of-Hearing Adults" (MaioranaBasas \& Pagliaro, 2014). The survey was disseminated through a secure web link provided by Qualtrics.com. Prior to disseminating the survey, permission was obtained through the West Virginia University Institutional Review Board.

\section{Measure}

The modified survey instrument format remained the same as "Technology Survey of Deaf and Hard-of-Hearing Adults" (Maiorana-Basas \& Pagliaro, 2014), with the exception of he option of questions being presented in American Sign Language for participants, and focused on technology used to design and deliver instruction. Additionally, technology use by instructors of $\mathrm{d} / \mathrm{hh}$ students with the express purpose of communication and collaboration questions were added and the focus shifted to changed specific types of technology used for instruction and learning. Additional questions were added to discover the teacher's use of more recently developed digital and mobile 
technology as well as current challenges using technology as reported by instructors of $\mathrm{d} / \mathrm{hh}$ students. In an effort to validate the survey instrument and its measures, the survey was pretested by experts in the field to help determine if the instrument would function properly as a valid and reliable social science research tool (Converse \& Presser, 1986). Although it would have been preferable to pre-test a subset of the sample population, the specialized nature of the population (i.e. certified teachers of deaf and hard-of-hearing students in the United States) being sampled, is small and to pretest a subset of the sample population might have diminished the survey return and increased the margin of error for the level of confidence (Rea \& Parker, 2014).

Outcomes included four distinct variables: technology use for designing and delivering instruction, technology for communication and collaboration, challenges in using technology, and professional development. These variables were measured on a continuous four-point Likert-type scale in the questionnaire (Frequently, Sometimes, Rarely, and Never). To ensure adequate statistical power, each area was represented by at least two items in the survey instrument.

The survey consisted of four multipart questions addressing: (1) use (e.g. frequently, sometimes, rarely, never) and preference of technology to design and deliver content-based learning activities (twenty-three subquestions), (2) use and preference of technology to promote communication and collaboration for learning (twenty-two subquestions), (3) use and preference of additional training or information on technology use for instruction (three questions with seven subquestions), and (4) frequency (e.g. frequently, sometimes, rarely, never) and types of challenges in using technology for 
instruction (twelve subquestions). Eight final questions addressed the demographic information of the participants.

\section{Data Analysis}

Descriptive statistics were used to analyze and report the basic features of the numerical data collected, via either summary or visual representation, i.e. graphs or tables, as guided by the research objectives (Curl \& Mann, 2001; Trochim, 2006). Chisquare tests and/or Fischer's exact test were used to determine what, if any, relationship was present between categorical variables. In the case of comparing two ranked variables, the Spearman-Rho correlation was performed to determine the degree of association between the two ordinal variables in question (Cohen, Cohen, West, \& Aiken, 2015).

Due to the large data set, the continuous four-point Likert scale was collapsed from (Frequently, Sometimes, Rarely, and Never) into dichotomous categories (Often, Not Often). This method of collapsing was constant across items. Collapsing response categories was intended to improve the intelligibility of the outcomes of analysis. This strategy for data analysis involves the strong assumption that Likert scale items are not interval data (Beamish, 2004). The assumption follows that intervals between the Likert scale points remains uncertain and unquantifiable. Further justification for collapsing response categories comes from Beamish (2004), who states that when undertaking descriptive analyses employing tables or graphs, it is clear that collapsing responses into dichotomous categories has distinct advantages in terms of capturing trends in the data. 


\section{Chapter Four: Results}

\section{Research Findings}

This study was designed to answer four research questions, with subquestions, pertaining to the use of technology by teachers of deaf and hard-of-hearing $(\mathrm{d} / \mathrm{hh})$ students in the United States and the challenges they encounter. Chapter four describes the research questions and how these questions were represented in the online survey distributed through Qualtrics. The survey consisted of four multipart questions and eight demographic questions to answer four research questions regarding the use and frequency of technology used in educating students with hearing loss put forth by the researcher.

Data from the survey were analyzed using Statistical Package for the Social Sciences (SPSS) software. Frequency counts, chi-square analyses, and Fisher's exact tests were conducted to determine the frequency, kinds of technology, and for what purpose the teachers of $\mathrm{d} / \mathrm{hh}$ students used various types of technology. The SpearmanRho correlation was performed to determine the degree of association between the selfreported use of technology by teacher of $\mathrm{d} / \mathrm{hh}$ students for additional training and the frequency of professional development provided by the employer.

A total of 1,711 individuals were contacted via email. Four hundred and thirtytwo emails did not reach the supervisors or teachers indicated by the email message bouncing back. One week after the initial contact, a follow-up email was sent reminding the supervisors and teachers of the study, thanking them for participating, and asking them to share the information about the survey with their staff if they had not already done so. Two weeks after the initial email message a final email was sent to thank them for participating and conclude the survey. 
A total of 369 people, $22 \%$ of the individuals contacted, completed the survey. This is comparable with an average return rate of $23 \%$ for online surveys (Nulty, 2008). Internet response rates are generally lower than other survey methods but tend to vary considerably depending on the population being surveyed (Vehovar \& Manfreda, 2008). Participants represented all five regions of the United States (Northeast, Southeast, Midwest, Southwest, and West). Approximately one-quarter of the sample indicated that they taught in a suburban setting $(26.8 \% ; \mathrm{N}=99), 26.3 \%(\mathrm{~N}=97)$ indicated that they taught in an urban setting, and $11.9 \%(\mathrm{~N}=44)$ taught in a rural setting. Another $35.0 \%$ $(\mathrm{N}=129)$ did not indicate the environment in which they teach.

Of all the participants, $37.1 \%(\mathrm{~N}=137)$ indicated that they teach in a school for the deaf, $10.0 \%(\mathrm{~N}=37)$ are itinerant teachers, $7.9 \%(\mathrm{~N}=29)$ teach in a resource room, $1.6 \%(\mathrm{~N}=6)$ teach in a college setting, $2.7 \%(\mathrm{~N}=10)$ indicated that they teach in more than one setting and $40.7 \%(\mathrm{~N}=150)$ teach in another setting not listed in the survey.

In terms of the level of students taught, $6.2 \%$ of the sample $(\mathrm{N}=23)$ teach pre-K, $15.4 \%(\mathrm{~N}=57)$ teach elementary, $20.1 \%(\mathrm{~N}=74)$ teach secondary, $1.9 \%(\mathrm{~N}=7)$ teach post-secondary, and $20.6 \%(\mathrm{~N}=76)$ teach at more than one level. Another $35.8 \%(\mathrm{~N}=$ 132) teach another level not listed in the survey. The following data analysis is arranged by research question.

\section{Research Question 1: Designing and Delivering Instruction}

Table 1 presents a visual representation of the basic frequencies of how often practicing teachers of $\mathrm{d} / \mathrm{hh}$ students use technology to design and deliver academic content-based learning activities. 
Table 1.

Frequencies with which teachers use technology to design and deliver academic contentbased learning activities.

\begin{tabular}{|c|c|c|c|}
\hline Type of technology & $\mathbf{N}$ & Use often (\%) & Use not often (\%) \\
\hline \multicolumn{4}{|l|}{ For design } \\
\hline Writing/Document software & 288 & 92 & 8 \\
\hline Presentation software & 287 & 82.9 & 17.1 \\
\hline Spreadsheet software & 284 & 36.6 & 63.4 \\
\hline Video editing software & 287 & 49.8 & 50.2 \\
\hline Photo editing software & 288 & 46.2 & 53.8 \\
\hline Other & 135 & 66.7 & 33.3 \\
\hline \multicolumn{4}{|l|}{ For delivery } \\
\hline Text Messaging & 271 & 24.7 & 75.3 \\
\hline Email & 271 & 53.5 & 46.5 \\
\hline Phone/Videophone & 271 & 33.2 & 66.8 \\
\hline Social Media & 272 & 22.4 & 77.6 \\
\hline Search Engines & 272 & 91.2 & 8.8 \\
\hline Word Processing & 272 & 86.8 & 13.2 \\
\hline Education Apps & 271 & 57.9 & 42.1 \\
\hline Posting Videos, Vlogs & 269 & 52.0 & 48.0 \\
\hline Educational Videos & 270 & 69.6 & 30.4 \\
\hline Academic Services & 271 & 60.1 & 39.9 \\
\hline News/information website & 270 & 54.1 & 45.9 \\
\hline ASL Dictionary & 271 & 60.9 & 39.1 \\
\hline Virtual Immersion & 267 & 9 & 91 \\
\hline Learning Management System & 270 & 34.8 & 65.2 \\
\hline Virtual Assistants/Agents & 268 & 6.7 & 93.3 \\
\hline Podcasts/Vodcasts & 269 & 11.9 & 88.1 \\
\hline Educational services & 271 & 55 & 45 \\
\hline
\end{tabular}

At 92\%, writing/document software (e.g. Word, Pages) was reported to be the most often used type of technology to develop and deliver instruction. Search engines (e.g. Google, Yahoo) were also reported as being used very often (91.2\%), to design and deliver instruction. Virtual Assistants/Agents (93.3 \%), and Virtual Immersion (91\%) were reported to be the least often used technology for designing and delivering instruction by participants, at this time. 


\section{Research Question 1a: Job Position}

The researcher conducted a series of chi-square analyses to answer research question 1a: is there a relationship between frequency of technology use to design and deliver academic content-based learning activities and job position including: instructional setting, geographic location, and academic level. First, the researcher examined whether a relationship exists between frequency of technology used to design and deliver academic content-based learning activities and the setting in which the teacher currently works (see Table 2). Due to small expected cell counts, Fisher's exact test was used to test the relationships. Where a significant relationship emerged, the researcher examined the adjusted standardized residuals to identify what was driving the significant findings. 
Table 2.

Chi-square analysis for relations between setting in which teacher works and use of technology for design and delivery.

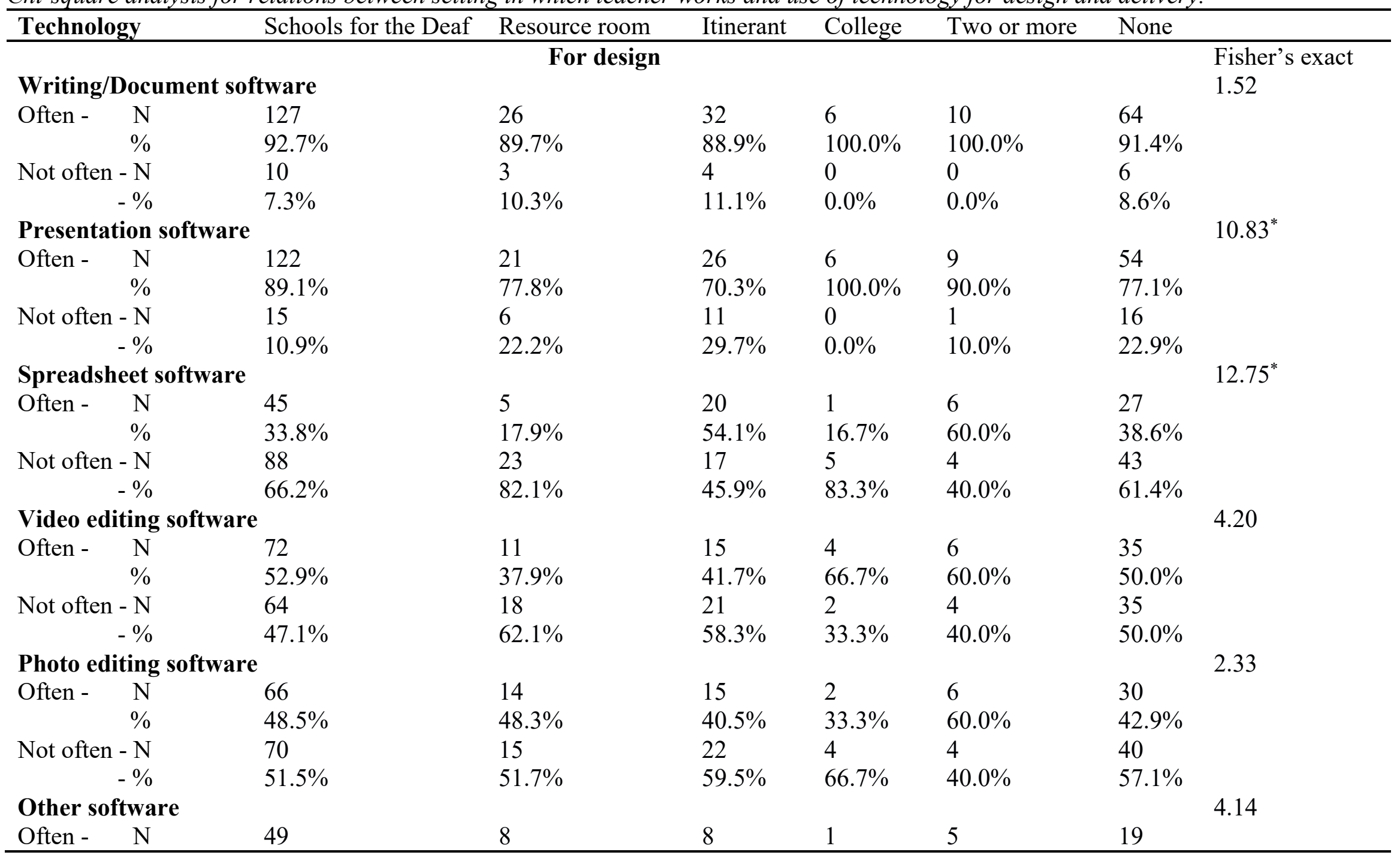




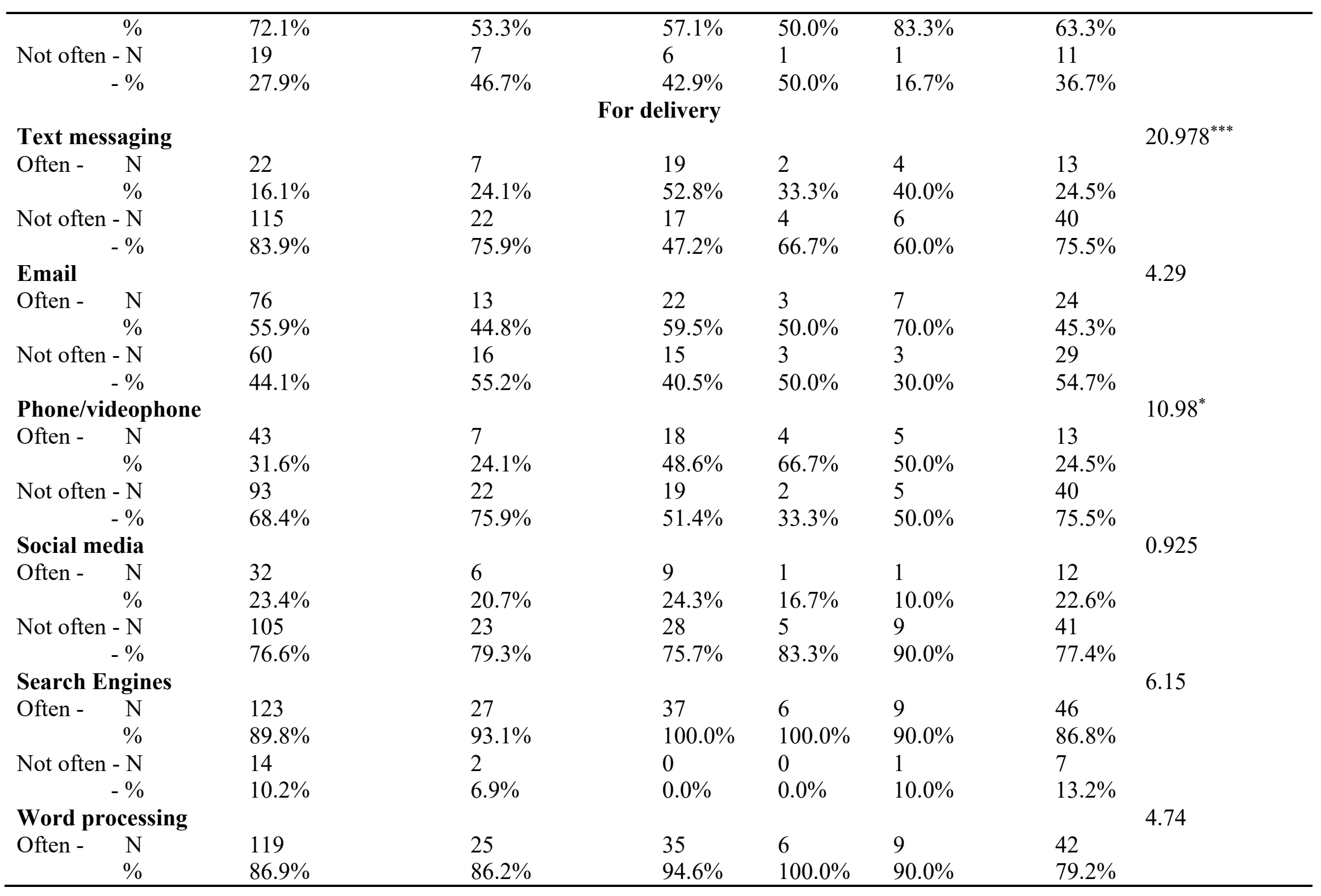




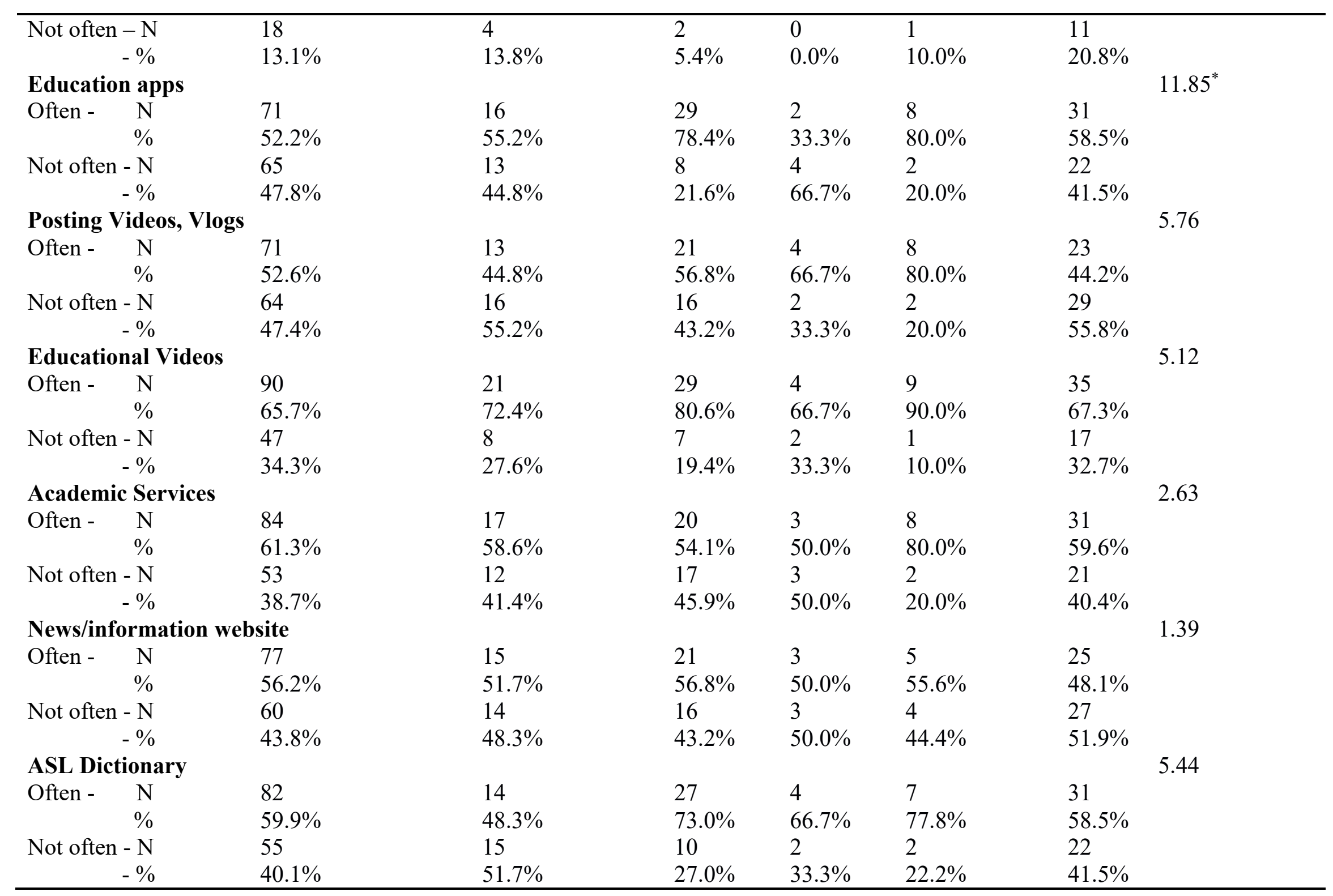




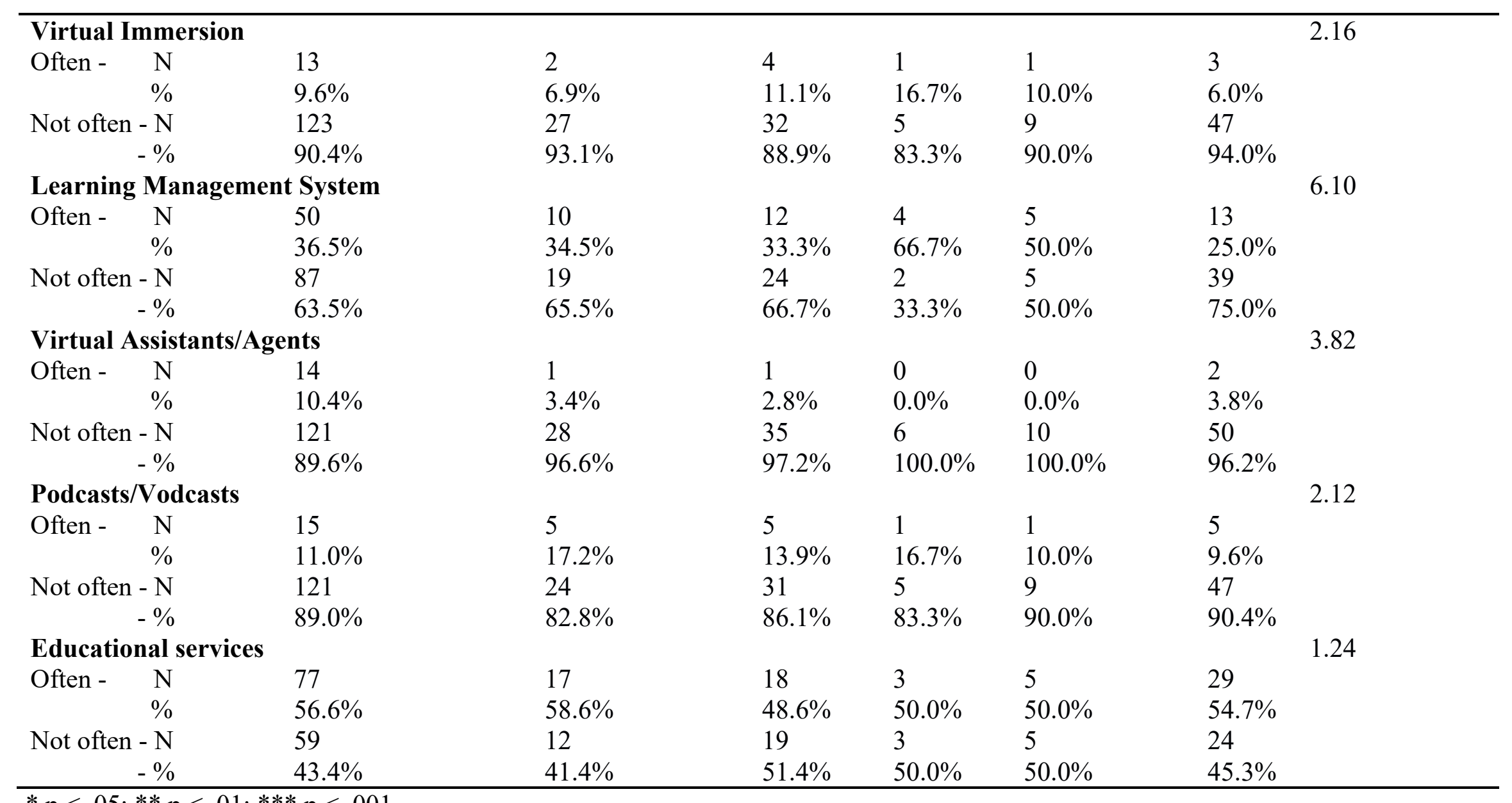

$* \mathrm{p}<.05 ; * * \mathrm{p}<.01 ; * * * \mathrm{p}<.001$ 
These results indicated that those teachers in schools for the deaf used presentation software for design more frequently than teachers in resources rooms or itinerant teachers. Itinerant teachers reported using spreadsheet software for design more frequently and resource room teachers used it less frequently. The itinerant teachers also reported using text messaging, phone/video phone and education apps for delivery more frequently than those teachers in schools for the deaf.

Next, the researcher examined whether a relationship exists between frequency of technology used to design and deliver academic content-based learning activities and the geographic location in which the teacher works (see Table 3). Where a significant relationship emerged, the researcher examined the adjusted standardized residuals to identify what was driving the significant finding.

Table 3. Chi-square analysis for relations between geographic location in which teacher works and use of technology for design and delivery.

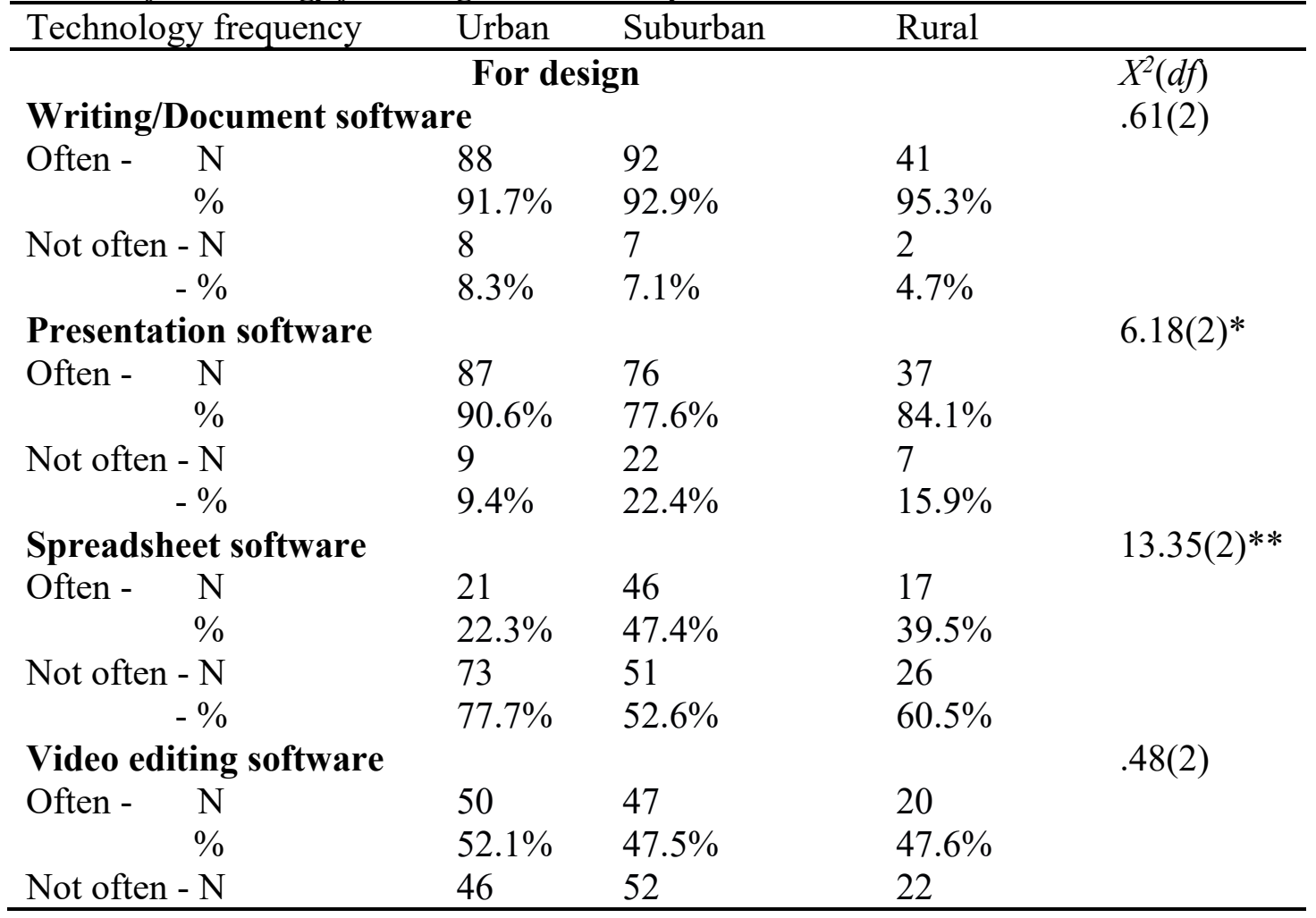




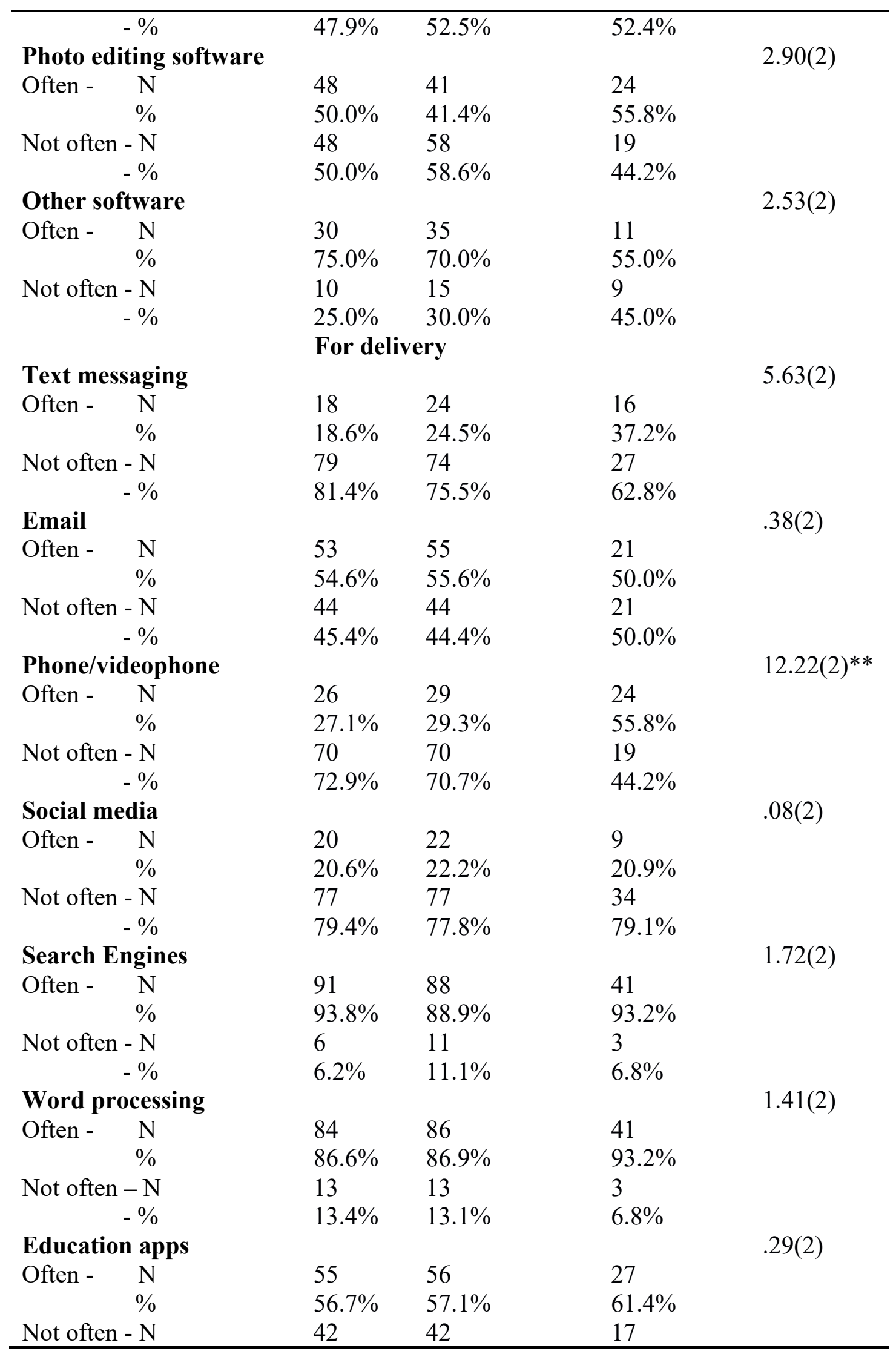




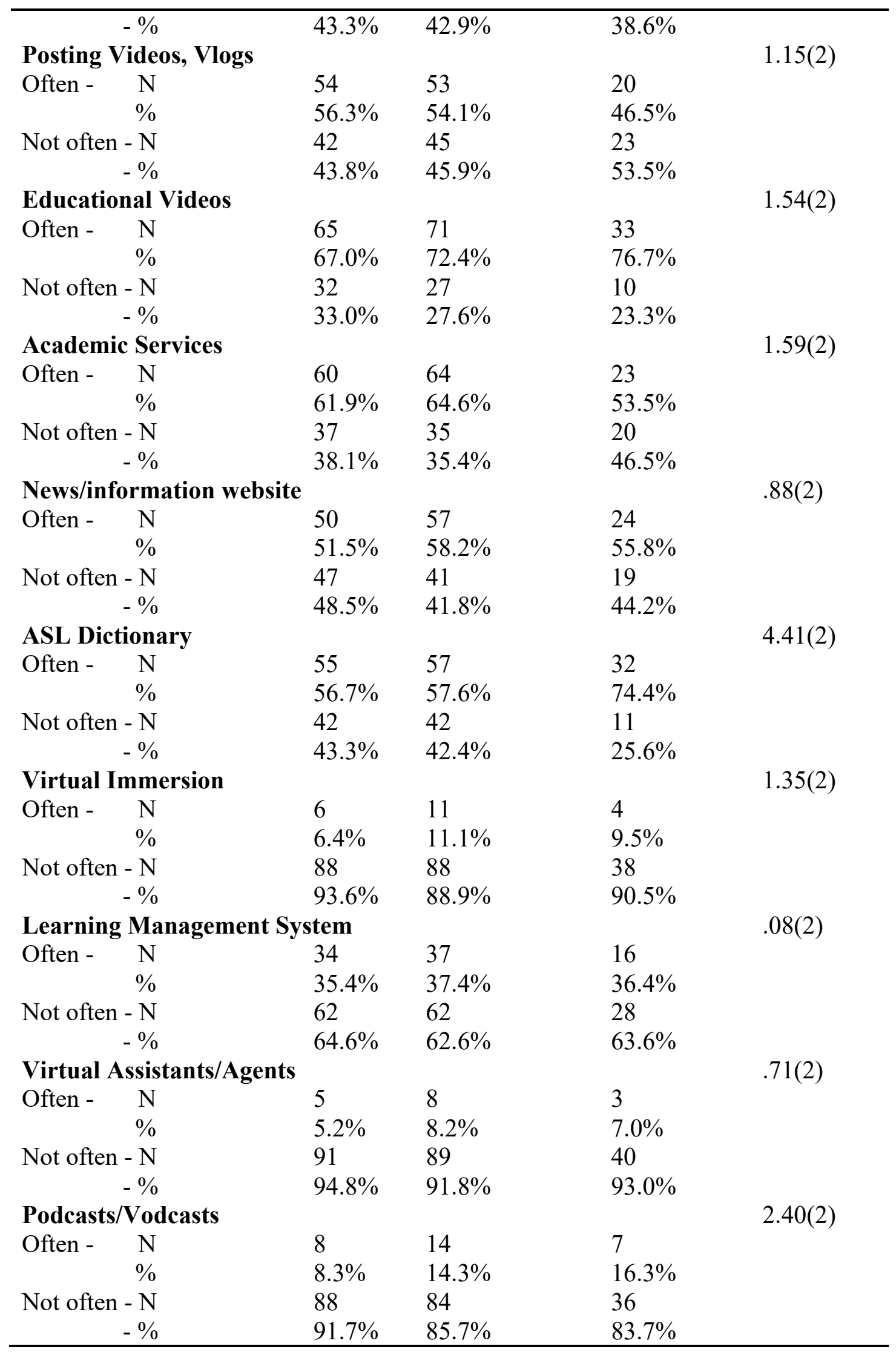




\begin{tabular}{|c|c|c|c|c|}
\hline \multicolumn{4}{|c|}{ Educational services } & \multirow[t]{3}{*}{$7.14(2)^{*}$} \\
\hline Often - $\quad \mathrm{N}$ & 50 & 64 & 19 & \\
\hline$\%$ & $51.5 \%$ & $65.3 \%$ & $43.2 \%$ & \\
\hline Not often - N & 47 & 34 & 25 & \\
\hline$-\%$ & $48.5 \%$ & $34.7 \%$ & $56.8 \%$ & \\
\hline
\end{tabular}

The data suggests that those educators of $\mathrm{d} / \mathrm{hh}$ students who teach in urban

settings use presentation software more frequently for design and those in suburban setting used presentation software less frequently. Those teachers of $\mathrm{d} / \mathrm{hh}$ students employed in suburban settings use spreadsheet software more frequently for design, whereas those in urban settings, use it less frequently. Those in rural settings reported using phone/video phone more often for delivery. Whereas those in suburban settings reported using educational services for delivery of content-based learning activities more often.

Finally, the researcher examined whether a relationship exists between frequency of technology used to design and deliver academic content-based learning activities and the academic level of the $\mathrm{d} / \mathrm{hh}$ students taught (see Table 4). Because of small expected cell counts, Fisher's exact test was used to test the relationships. Where a significant relationship emerged, the researcher examined the adjusted standardized residuals to identify what was driving the significant finding. 
Table 4.

Chi-square analysis for relations between level of students and use of technology for design and delivery.

\begin{tabular}{|c|c|c|c|c|c|c|c|}
\hline Technology & Pre-K & Elementary & Secondary & Post-secondary & Two or more & Other & \\
\hline \multirow{2}{*}{\multicolumn{7}{|c|}{ Writing/Document software }} & Fisher's exact \\
\hline & & & & & & & 4.19 \\
\hline \multirow[t]{2}{*}{ Often - } & 23 & 53 & 67 & 6 & 69 & 47 & \\
\hline & $100.0 \%$ & $94.6 \%$ & $90.5 \%$ & $85.7 \%$ & $92.0 \%$ & $88.7 \%$ & \\
\hline Not often - N & 0 & 3 & 7 & 1 & 6 & 6 & \\
\hline$-\%$ & $0.0 \%$ & $5.4 \%$ & $9.5 \%$ & $14.3 \%$ & $8.0 \%$ & $11.3 \%$ & \\
\hline \multicolumn{2}{|c|}{ Presentation software } & & & & & & 6.51 \\
\hline \multirow[t]{2}{*}{ Often - } & 16 & 47 & 67 & 6 & 62 & 40 & \\
\hline & $72.7 \%$ & $83.9 \%$ & $90.5 \%$ & $85.7 \%$ & $81.6 \%$ & $76.9 \%$ & \\
\hline Not often - N & 6 & 9 & 7 & 1 & 14 & 12 & \\
\hline$-\%$ & $27.3 \%$ & $16.1 \%$ & $9.5 \%$ & $14.3 \%$ & $18.4 \%$ & $23.1 \%$ & \\
\hline \multicolumn{2}{|c|}{ Spreadsheet software } & & & & & & $14.59 *$ \\
\hline \multirow[t]{2}{*}{ Often - } & 5 & 11 & 30 & 1 & 35 & 22 & \\
\hline & $23.8 \%$ & $19.6 \%$ & $41.7 \%$ & $14.3 \%$ & $46.7 \%$ & $41.5 \%$ & \\
\hline Not often - N & 16 & 45 & 42 & 6 & 40 & 31 & \\
\hline$-\%$ & $76.2 \%$ & $80.4 \%$ & $58.3 \%$ & $85.7 \%$ & $53.3 \%$ & $58.5 \%$ & \\
\hline \multicolumn{2}{|c|}{ Video editing software } & & & & & & 3.23 \\
\hline \multirow[t]{2}{*}{ Often - } & 13 & 23 & 37 & 4 & 40 & 26 & \\
\hline & $56.5 \%$ & $40.4 \%$ & $50.7 \%$ & $57.1 \%$ & $54.1 \%$ & $49.1 \%$ & \\
\hline Not often - N & 10 & 34 & 36 & 3 & 34 & 27 & \\
\hline$-\%$ & $43.5 \%$ & $59.6 \%$ & $49.3 \%$ & $42.9 \%$ & $45.9 \%$ & $50.9 \%$ & \\
\hline \multicolumn{2}{|c|}{ Photo editing software } & & & & & & $11.42 *$ \\
\hline \multirow[t]{2}{*}{ Often - } & 15 & 27 & 25 & 3 & 42 & 21 & \\
\hline & $65.2 \%$ & $47.4 \%$ & $34.2 \%$ & $42.9 \%$ & $56.0 \%$ & $39.6 \%$ & \\
\hline Not often - N & 8 & 30 & 48 & 4 & 33 & 32 & \\
\hline$-\%$ & $34.8 \%$ & $52.6 \%$ & $65.8 \%$ & $57.1 \%$ & $44.0 \%$ & $60.4 \%$ & \\
\hline
\end{tabular}




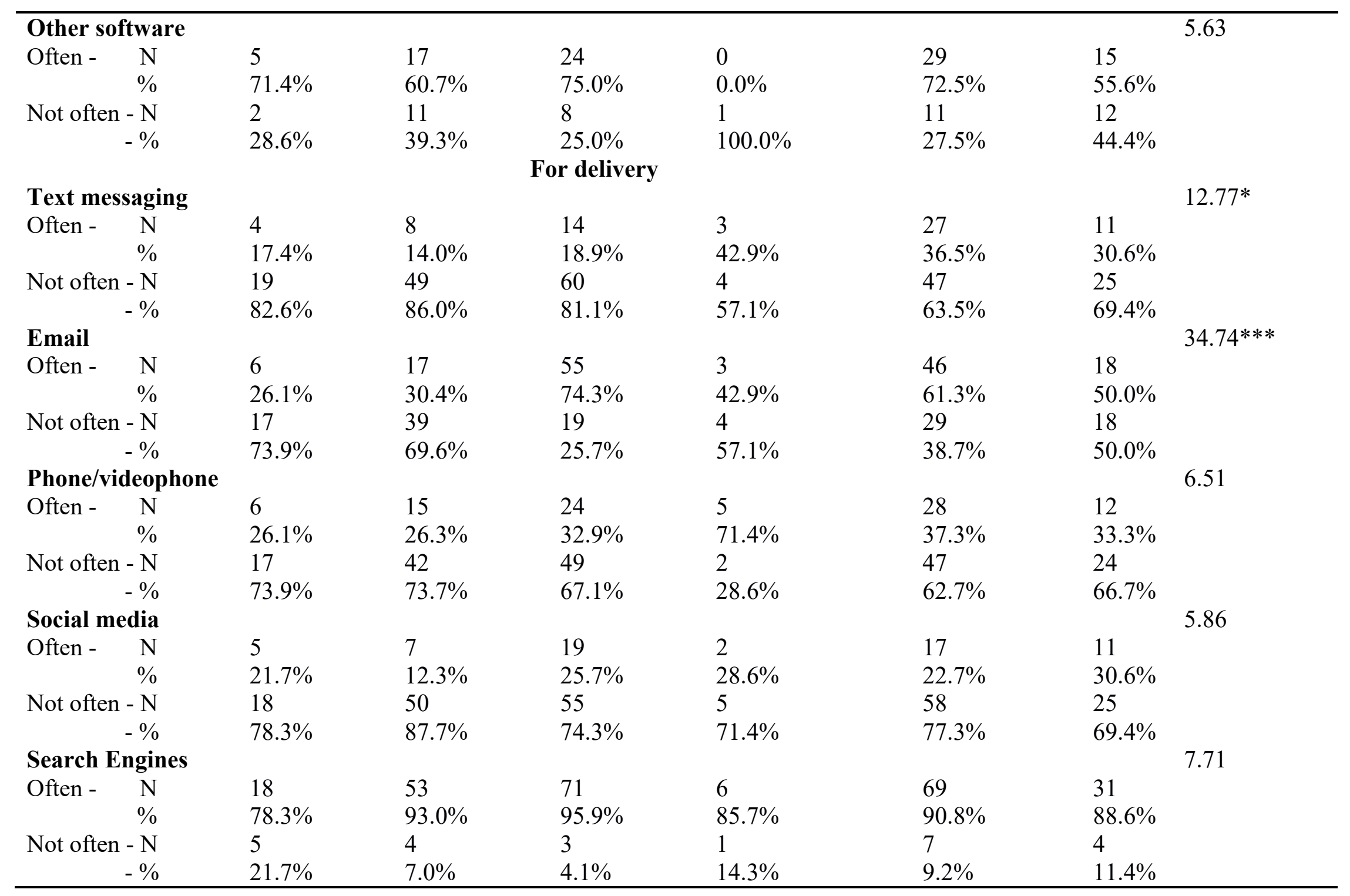




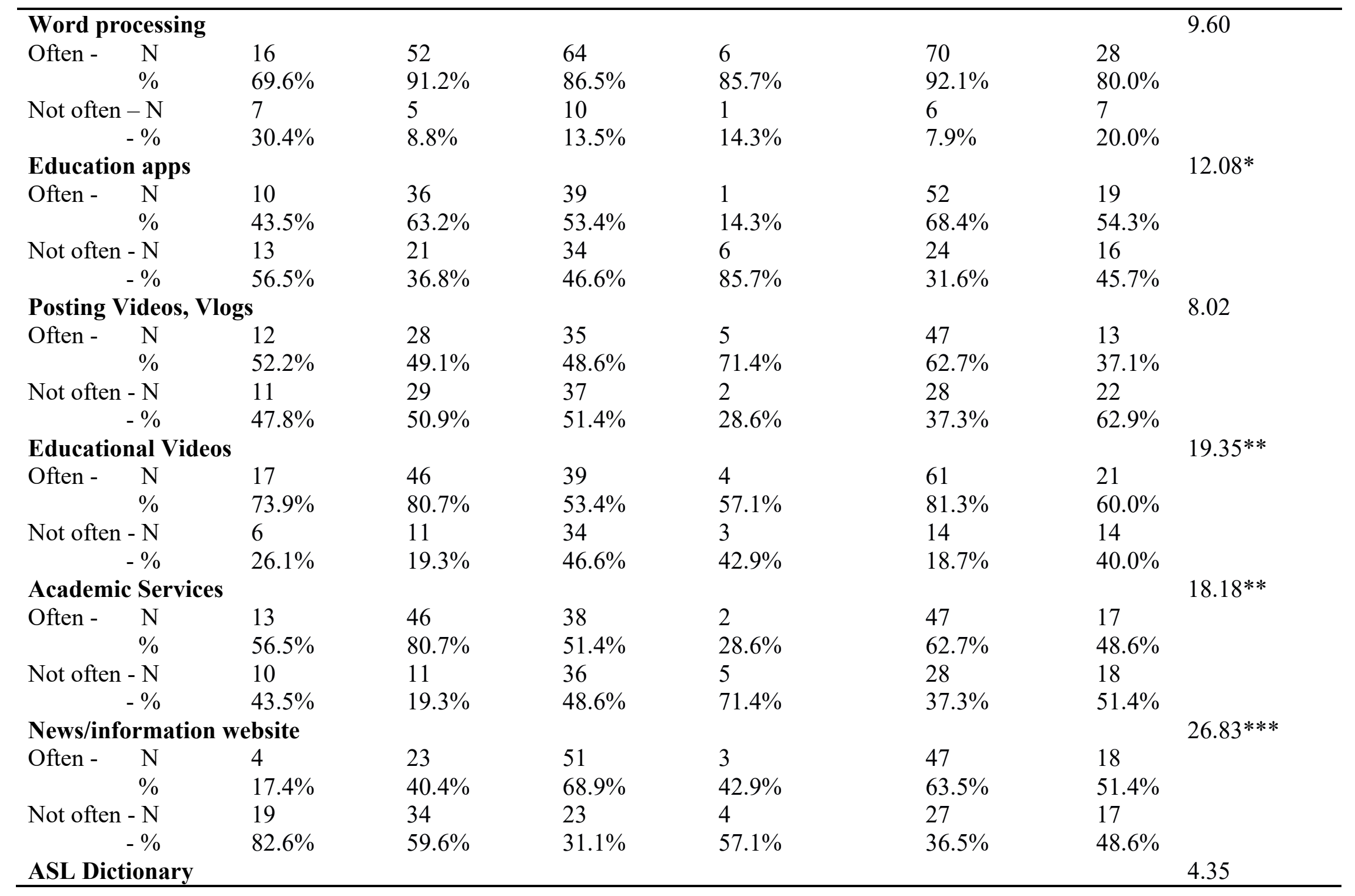




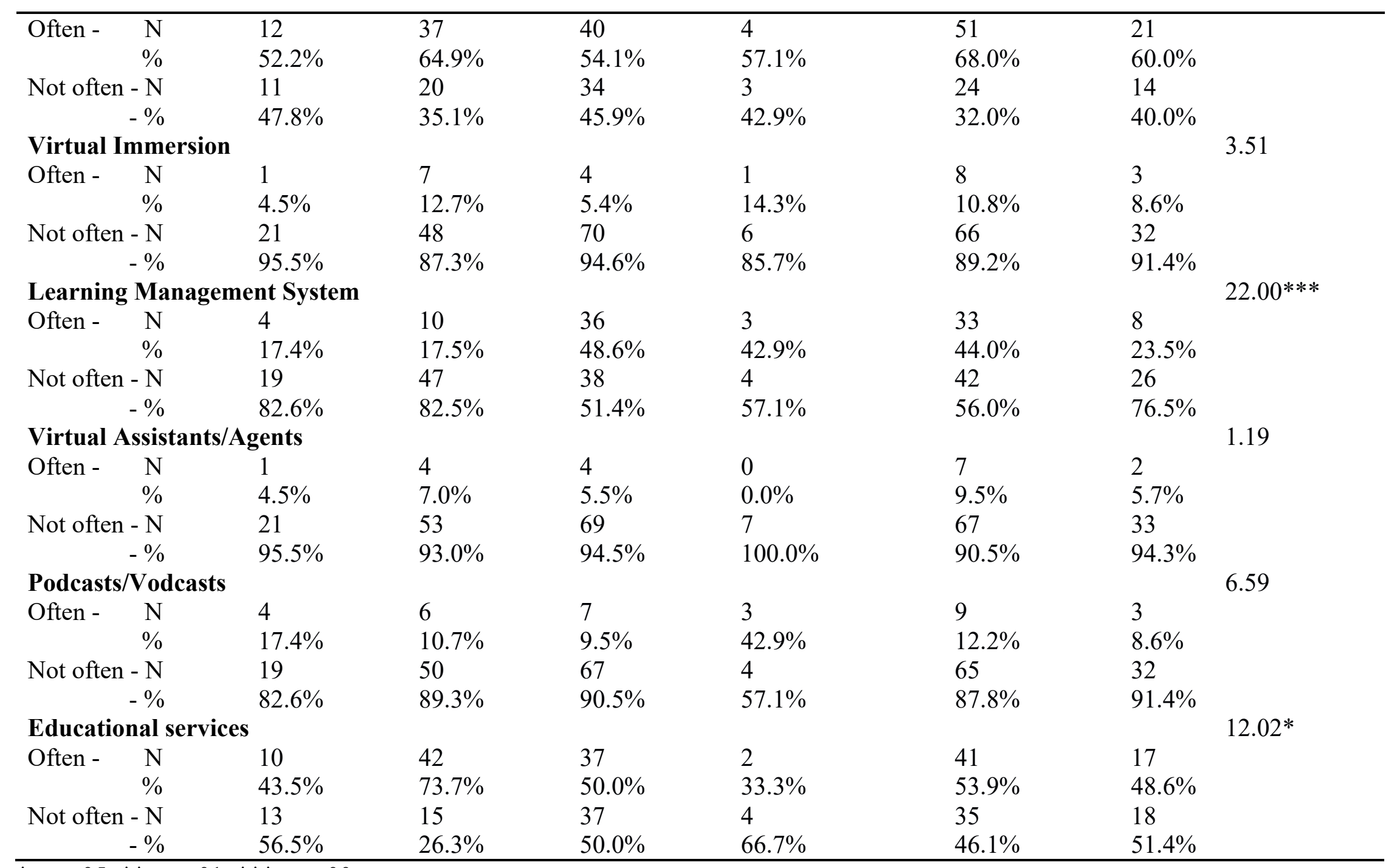

$* \mathrm{p}<.05 ; * * \mathrm{p}<.01 ; * * * \mathrm{p}<.00$ 
These results indicated that elementary school teachers of $d /$ hh students were less likely to use spreadsheet software for the design and delivery of content-based learning activities, while those teachers of $\mathrm{d} / \mathrm{hh}$ students working in two or more academic levels were more likely to use spreadsheet software. Secondary school teachers of d/hh students reported being less likely to use photo editing software for lesson design and delivery, while teachers of $\mathrm{d} / \mathrm{hh}$ students who reported working in two or more academic levels were more likely to use it. Elementary school teachers of $\mathrm{d} / \mathrm{hh}$ students reported being less likely to use texting for content design and delivery, while those teachers of $d / h h$ students who reported working in two or more academic levels were more likely to use texting to develop and deliver content.

Those educators of $\mathrm{d} / \mathrm{hh}$ students who reported working in pre-K and elementary school were less likely to use email for instruction while those who reported working in secondary schools were more likely to do so. Those educators in post-secondary schools reported being less likely to use education apps while those who reported working in two or more setting were more likely to use education apps for delivering content.

Teachers of $d / h h$ students in elementary school and those teaching in two or more educational setting reported being more likely to use education videos for content-based instruction, while those in secondary schools reported being less likely to do so. Elementary school teachers of $\mathrm{d} / \mathrm{hh}$ students also reported using academic/education services for content-based learning activities. Those teachers in pre-K and elementary schools were less likely to use news/information websites for delivery while secondary teachers of $\mathrm{d} / \mathrm{hh}$ students were more likely to do so. 
Teacher of $\mathrm{d} / \mathrm{hh}$ students in elementary schools were less likely to use a learning management system for content-based learning activities. However, those in secondary schools and those who reported working in two or more academic level were more likely to use learning management systems for content-based learning activities.

\section{Research Question 1b: Technology Use for Additional Training}

To examine if there a relationship between use of technology to design and deliver academic content-based learning activities and use of technology for obtaining additional training, the researcher conducted chi-square analyses (see Table 5). Where a significant relationship emerged, the researcher examined the adjusted standardized residuals to identify what was driving the significant finding.

Table 5.

Chi-square analysis examining relationship between use of technology for additional training and use of technology for designing and delivery of academic content.

\begin{tabular}{|c|c|c|c|}
\hline Technology & $\begin{array}{l}\text { Uses technology for } \\
\text { training }\end{array}$ & \multirow[t]{2}{*}{$\begin{array}{l}\text { Does not use technology for } \\
\text { training }\end{array}$} & \\
\hline & For designi & & $X^{2}(d f)$ \\
\hline \multicolumn{3}{|c|}{ Writing/Document software } & $.98(1)$ \\
\hline \multirow[t]{2}{*}{ Often - } & 99 & 166 & \\
\hline & $90.0 \%$ & $93.3 \%$ & \\
\hline Not often - N & 11 & 12 & \\
\hline$-\%$ & $10.0 \%$ & $6.7 \%$ & \\
\hline \multicolumn{3}{|c|}{ Presentation software } & $4.51(1)^{*}$ \\
\hline \multirow[t]{2}{*}{ Often - } & 83 & 155 & \\
\hline & $76.9 \%$ & $86.6 \%$ & \\
\hline Not often - N & 25 & 24 & \\
\hline$-\%$ & $23.1 \%$ & $13.4 \%$ & \\
\hline \multicolumn{4}{|c|}{ Spreadsheet software } \\
\hline \multirow[t]{2}{*}{ Often - } & 37 & 67 & $.42(1)$ \\
\hline & $34.3 \%$ & $38.1 \%$ & \\
\hline Not often - N & 71 & 109 & \\
\hline$-\%$ & $65.7 \%$ & $61.9 \%$ & \\
\hline \multicolumn{2}{|c|}{ Video editing software } & & $.01(1)$ \\
\hline Often - & 54 & 89 & \\
\hline$\%$ & $49.5 \%$ & $50.0 \%$ & \\
\hline Not often - N & 55 & 89 & \\
\hline$-\%$ & $50.5 \%$ & $50.0 \%$ & \\
\hline
\end{tabular}




\begin{tabular}{|c|c|c|c|}
\hline \multicolumn{3}{|c|}{ Photo editing software } & \multirow[t]{3}{*}{$2.31(1)$} \\
\hline \multirow[t]{2}{*}{ Often - } & 45 & 88 & \\
\hline & $40.5 \%$ & $49.7 \%$ & \\
\hline Not often - N & 66 & 89 & \\
\hline$-\%$ & $59.5 \%$ & $50.3 \%$ & \\
\hline \multicolumn{4}{|c|}{ Other software } \\
\hline \multirow[t]{2}{*}{ Often - } & 31 & 59 & $1.89(1)$ \\
\hline & $59.6 \%$ & $71.1 \%$ & \\
\hline Not often - N & 21 & 24 & \\
\hline$-\%$ & $40.4 \%$ & $28.9 \%$ & \\
\hline \multicolumn{3}{|c|}{ For delivery } & \\
\hline \multicolumn{3}{|c|}{ Text messaging } & $1.98(1)$ \\
\hline \multirow[t]{2}{*}{ Often - } & 28 & 39 & \\
\hline & $29.8 \%$ & $22.0 \%$ & \\
\hline Not often - N & 66 & 138 & \\
\hline$-\%$ & $70.2 \%$ & $78.0 \%$ & \\
\hline \multicolumn{2}{|l|}{ Email } & & $.93(1)$ \\
\hline \multirow[t]{2}{*}{ Often - } & 46 & 99 & \\
\hline & $49.5 \%$ & $55.6 \%$ & \\
\hline Not often - N & 47 & 79 & \\
\hline & $50.5 \%$ & $44.4 \%$ & \\
\hline \multicolumn{4}{|c|}{ Phone/videophone } \\
\hline \multirow[t]{2}{*}{ Often - } & 36 & 54 & $1.68(1)$ \\
\hline & $38.3 \%$ & $30.5 \%$ & \\
\hline Not often - N & 58 & 123 & \\
\hline \multirow{2}{*}{\multicolumn{4}{|c|}{$\begin{array}{r}-\% \\
\text { Social media }\end{array}$}} \\
\hline & & & \\
\hline \multirow[t]{2}{*}{ Often - } & 23 & 38 & $.34(1)$ \\
\hline & $24.5 \%$ & $21.3 \%$ & \\
\hline Not often - N & 71 & 140 & \\
\hline \multirow{2}{*}{\multicolumn{2}{|c|}{$\begin{array}{c}-\% \\
\text { Search Engines }\end{array}$}} & $78.7 \%$ & \\
\hline & & & \\
\hline \multirow[t]{2}{*}{ Often - } & 84 & 164 & $.13(1)$ \\
\hline & $90.3 \%$ & $91.6 \%$ & \\
\hline Not often - N & 9 & 15 & \\
\hline$-\%$ & $9.7 \%$ & $8.4 \%$ & \\
\hline Word proces & & & $1.94(1)$ \\
\hline Often - & 77 & 159 & \\
\hline$\%$ & $82.8 \%$ & $88.8 \%$ & \\
\hline Not often $-\mathrm{N}$ & 16 & 20 & \\
\hline$-\%$ & $17.2 \%$ & $11.2 \%$ & \\
\hline Education ap & & & $.00(1)$ \\
\hline Often - N & 54 & 103 & \\
\hline$\%$ & $58.1 \%$ & $57.9 \%$ & \\
\hline Not often - N & 39 & 75 & \\
\hline$-\%$ & $41.9 \%$ & $42.1 \%$ & \\
\hline
\end{tabular}




\begin{tabular}{|c|c|c|c|}
\hline \multicolumn{4}{|c|}{ Posting Videos, Vlogs } \\
\hline \multirow[t]{2}{*}{ Often - } & 50 & 90 & $.17(1)$ \\
\hline & $53.8 \%$ & $51.1 \%$ & \\
\hline Not often - N & 43 & 86 & \\
\hline$-\%$ & $46.2 \%$ & $48.9 \%$ & \\
\hline \multicolumn{3}{|c|}{ Educational Videos } & $.59(1)$ \\
\hline \multirow[t]{2}{*}{ Often - } & 62 & 126 & \\
\hline & $66.7 \%$ & $71.2 \%$ & \\
\hline Not often - N & 31 & 51 & \\
\hline$-\%$ & $33.3 \%$ & $28.8 \%$ & \\
\hline \multicolumn{4}{|c|}{ Academic Services } \\
\hline \multirow[t]{2}{*}{ Often - } & 48 & 115 & $4.30(1)^{*}$ \\
\hline & $51.6 \%$ & $64.6 \%$ & \\
\hline Not often - N & 45 & 63 & \\
\hline$-\%$ & $48.4 \%$ & $35.4 \%$ & \\
\hline \multicolumn{3}{|c|}{ News/information website } & $1.85(1)$ \\
\hline \multirow[t]{2}{*}{ Often - } & 45 & 101 & \\
\hline & $48.4 \%$ & $57.1 \%$ & \\
\hline Not often - N & 48 & 76 & \\
\hline$-\%$ & $51.6 \%$ & $42.9 \%$ & \\
\hline \multicolumn{3}{|c|}{ ASL Dictionary } & $.01(1)$ \\
\hline \multirow[t]{2}{*}{ Often - } & 57 & 108 & \\
\hline & $61.3 \%$ & $60.7 \%$ & \\
\hline Not often - N & 36 & 70 & \\
\hline$-\%$ & $38.7 \%$ & $39.3 \%$ & \\
\hline \multicolumn{2}{|l|}{ Virtual } & & $1.12(1)$ \\
\hline \multicolumn{3}{|l|}{ Immersion } & \\
\hline \multirow[t]{2}{*}{ Often - } & 6 & 18 & \\
\hline & $6.5 \%$ & $10.3 \%$ & \\
\hline Not often - N & 87 & 156 & \\
\hline$-\%$ & $93.5 \%$ & $89.7 \%$ & \\
\hline \multicolumn{3}{|c|}{ Learning Management System } & $3.59(1)$ \\
\hline \multirow[t]{2}{*}{ Often - } & 25 & 69 & \\
\hline & $27.2 \%$ & $38.8 \%$ & \\
\hline Not often - N & 67 & 109 & \\
\hline$-\%$ & $72.8 \%$ & $61.2 \%$ & \\
\hline \multicolumn{2}{|c|}{ Virtual Assistants/Agents } & & $4.74(1)^{*}$ \\
\hline \multirow[t]{2}{*}{ Often - } & 2 & 16 & \\
\hline & $2.2 \%$ & $9.1 \%$ & \\
\hline Not often - N & 91 & 159 & \\
\hline$-\%$ & $97.8 \%$ & $90.9 \%$ & \\
\hline Podcasts/Voc & & & $.00(1)$ \\
\hline Often - $\quad \mathrm{N}$ & 11 & 21 & \\
\hline$\%$ & $11.8 \%$ & $11.9 \%$ & \\
\hline Not often - N & 82 & 155 & \\
\hline$-\%$ & $88.2 \%$ & $88.1 \%$ & \\
\hline
\end{tabular}




\begin{tabular}{rrlll}
\hline \multicolumn{3}{l}{ Educational services } & & $2.88(1)$ \\
Often - & $\mathrm{N}$ & 44 & 105 & \\
$\%$ & $47.8 \%$ & $58.7 \%$ & \\
Not often $-\mathrm{N}$ & 48 & 74 & \\
$-\%$ & $52.2 \%$ & $41.3 \%$ & \\
$* p<.05 ; * * p<.01 ; * * * p<.001$ & &
\end{tabular}

The results indicate that those teachers of $\mathrm{d} / \mathrm{hh}$ students who received additional training in technology use with $\mathrm{d} / \mathrm{hh}$ students were less likely to use presentation software for design, less likely to use academic services for delivery, and less likely to use virtual assistants for delivery of content-based learning activities than those who did not receive additional training.

\section{Research Question 2: Communication and Collaboration}

In order to examine the second research question, how often do practicing teachers of $\mathrm{d} / \mathrm{hh}$ students use technology to promote student communication and collaboration for learning, the researcher calculated basic frequencies (see Table 6).

Table 6.

Frequency of using technology for communication and collaboration.

\begin{tabular}{llll}
\hline Technology & $\mathrm{N}$ & \% Often & \% Not often \\
\hline For communication & & & \\
Laptop & 261 & 76.6 & 23.4 \\
iPad or Tablet & 261 & 79.7 & 20.3 \\
Smart Phone & 264 & 52.3 & 47.7 \\
Augmentative Communication Device & 265 & 16.2 & 83.8 \\
Translation Apps & 264 & 11.7 & 88.3 \\
Overhead Projector/ELMO & 265 & 50.9 & 49.1 \\
Interactive Whiteboard & 265 & 77.4 & 22.6 \\
Student/Learner Response System & 261 & 17.6 & 82.4 \\
Captioning and Text Interpreting & 263 & 24.0 & 76.0 \\
Video Remote Interpreting & 264 & 10.6 & 89.4 \\
Closed or Open Captioning & 263 & 85.2 & 14.8 \\
Other & 64 & 15.6 & 84.4 \\
For collaboration & & & \\
Text Messaging & 253 & 87.4 & 12.6 \\
E-Mail & 253 & 98.8 & 1.2 \\
Phone/Videophone & 254 & 73.6 & 26.4 \\
Social Media & 253 & 52.2 & 47.8 \\
\hline
\end{tabular}




\begin{tabular}{llll}
\hline School website/ Class Webpage & 253 & 48.6 & 51.4 \\
Professional Deaf-Specific Association & 250 & 42.4 & 57.6 \\
website(s) & & & \\
Organizational Websites & 254 & 74.0 & 26.0 \\
Presentation software & 254 & 68.1 & 31.9 \\
Word Processing & 253 & 83.0 & 17.0 \\
Other & 60 & 31.7 & 68.3 \\
\hline
\end{tabular}

Participants responses indicated that teachers of $\mathrm{d} / \mathrm{hh}$ students often use laptop computers, tablets, smart phones, interactive white boards, overhead projectors/ELMOs and close or open captioning for communication. These teachers report using augmentative devices, translation applications, captions/ text interpreting, student response systems, and video remote to communicate less often. In terms of collaboration, participants reported often using e-mail, text messaging, word processing, organizational websites, presentation software and social media as a means of collaboration. Less often, participants reported using professional-deaf specific association websites, school or class webpages for collaboration.

\section{Research Question 2a: Job Position}

In order to examine if there a relationship between use of technology to promote student communication and collaboration and the teacher's job position, the researcher conducted a series of chi-square analyses. First, the researcher examined the relationship between technology use for communication and collaboration and the setting in which the teacher currently works. Because of small expected cell counts, Fisher's exact test was used to test for the relationship (see Table 7). Where a significant relationship emerged, the researcher examined the adjusted standardized residuals to identify what was driving the significant findings. 
Table 7.

Chi-square analysis of relationship between using technology for communication and collaboration and the setting in which the teacher works.

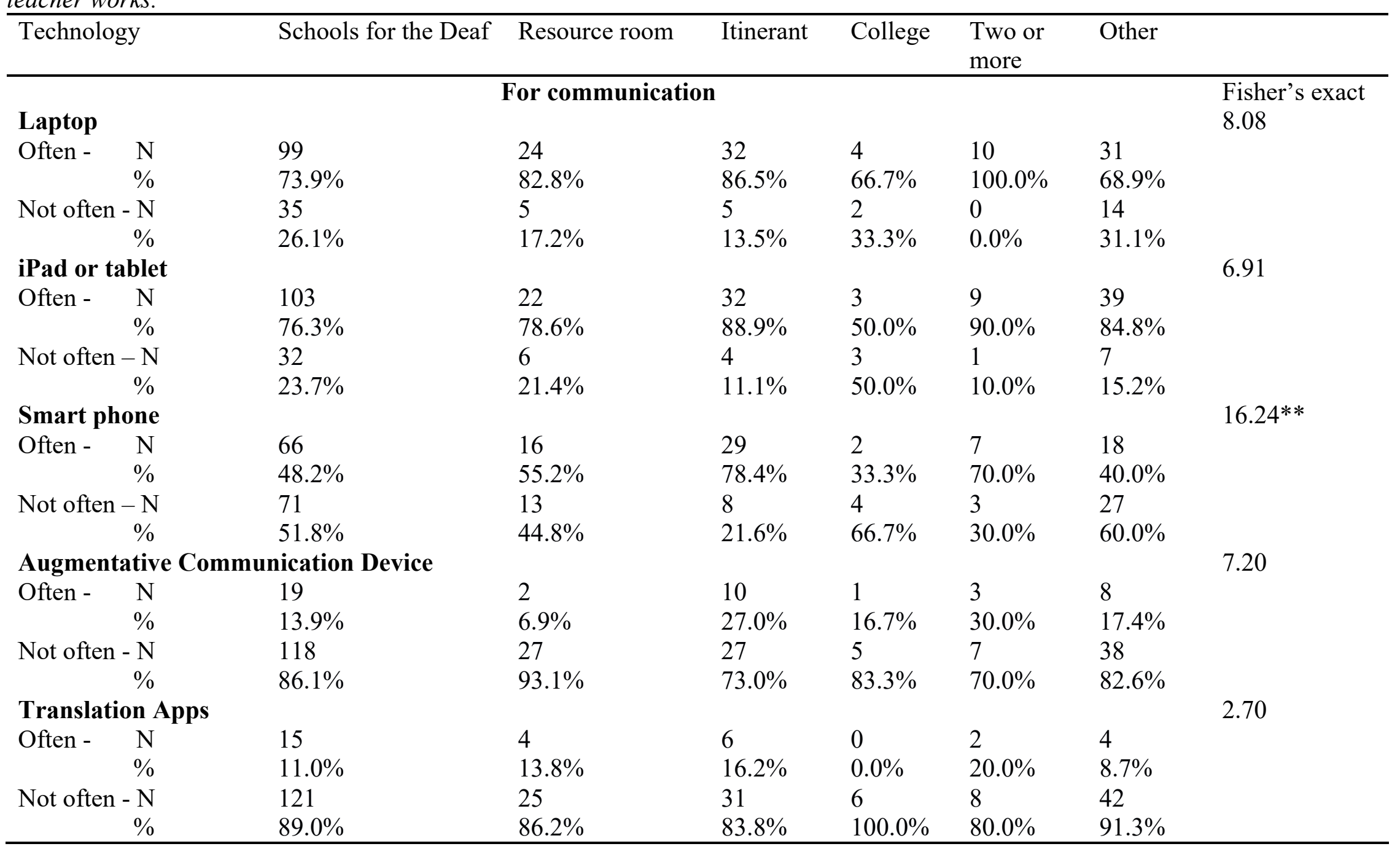




\begin{tabular}{|c|c|c|c|c|c|c|c|}
\hline \multicolumn{7}{|c|}{ Overhead Projector/ELMO } & \multirow[t]{3}{*}{$16.83 * *$} \\
\hline \multirow[t]{2}{*}{ Often - } & 70 & 18 & 11 & 5 & 9 & 22 & \\
\hline & $51.1 \%$ & $62.1 \%$ & $29.7 \%$ & $83.3 \%$ & $90.0 \%$ & $47.8 \%$ & \\
\hline Not often - N & 67 & 11 & 26 & 1 & 1 & 24 & \\
\hline$\%$ & $48.9 \%$ & $37.9 \%$ & $70.3 \%$ & $16.7 \%$ & $10.0 \%$ & $52.2 \%$ & \\
\hline \multicolumn{3}{|c|}{ Interactive Whiteboard } & & & & & $28.60 * * *$ \\
\hline \multirow[t]{2}{*}{ Often - } & 119 & 22 & 17 & 6 & 9 & 32 & \\
\hline & $86.9 \%$ & $75.9 \%$ & $45.9 \%$ & $100.0 \%$ & $90.0 \%$ & $69.6 \%$ & \\
\hline Not often - N & 18 & 7 & 20 & 0 & 1 & 14 & \\
\hline$\%$ & $13.1 \%$ & $24.1 \%$ & $54.1 \%$ & $0.0 \%$ & $10.0 \%$ & $30.4 \%$ & \\
\hline \multicolumn{3}{|c|}{ Student/Learner Response System } & & & & & 2.53 \\
\hline \multirow[t]{2}{*}{ Often - } & 22 & 6 & 6 & 0 & 3 & 9 & \\
\hline & $16.2 \%$ & $20.7 \%$ & $16.7 \%$ & $0.0 \%$ & $30.0 \%$ & $20.0 \%$ & \\
\hline Not often - N & 114 & 23 & 30 & 5 & 7 & 36 & \\
\hline$\%$ & $83.8 \%$ & $79.3 \%$ & $83.3 \%$ & $100.0 \%$ & $70.0 \%$ & $80.0 \%$ & \\
\hline \multicolumn{3}{|c|}{ Captioning and Text Interpreting } & & & & & $20.07 * *$ \\
\hline \multirow[t]{2}{*}{ Often - } & 20 & 7 & 18 & 1 & 4 & 13 & \\
\hline & $14.7 \%$ & $24.1 \%$ & $48.6 \%$ & $16.7 \%$ & $40.0 \%$ & $28.9 \%$ & \\
\hline Not often - N & 116 & 22 & 19 & 5 & 6 & 32 & \\
\hline$\%$ & $85.3 \%$ & $75.9 \%$ & $51.4 \%$ & $83.3 \%$ & $60.0 \%$ & $71.1 \%$ & \\
\hline \multicolumn{3}{|c|}{ Video Remote Interpreting } & & & & & 9.42 \\
\hline \multirow[t]{2}{*}{ Often - } & 11 & 3 & 8 & 0 & 3 & 3 & \\
\hline & $8.0 \%$ & $10.3 \%$ & $21.6 \%$ & $0.0 \%$ & $30.0 \%$ & $6.7 \%$ & \\
\hline Not often - N & 126 & 26 & 29 & 6 & 7 & 42 & \\
\hline \multirow{2}{*}{\multicolumn{2}{|c|}{ Closed or Open Captioning }} & $89.7 \%$ & $78.4 \%$ & $100.0 \%$ & $70.0 \%$ & $93.3 \%$ & \\
\hline & & & & & & & 4.56 \\
\hline \multirow[t]{2}{*}{ Often - } & 117 & 22 & 30 & 6 & 10 & 39 & \\
\hline & $85.4 \%$ & $75.9 \%$ & $81.1 \%$ & $100.0 \%$ & $100.0 \%$ & $88.6 \%$ & \\
\hline \multirow{2}{*}{$\begin{array}{r}\text { Not often }-\mathrm{N} \\
\%\end{array}$} & 20 & 7 & 7 & 0 & 0 & 5 & \\
\hline & $14.6 \%$ & $24.1 \%$ & $18.9 \%$ & $0.0 \%$ & $0.0 \%$ & $11.4 \%$ & \\
\hline Other & & & & & & & 2.50 \\
\hline
\end{tabular}




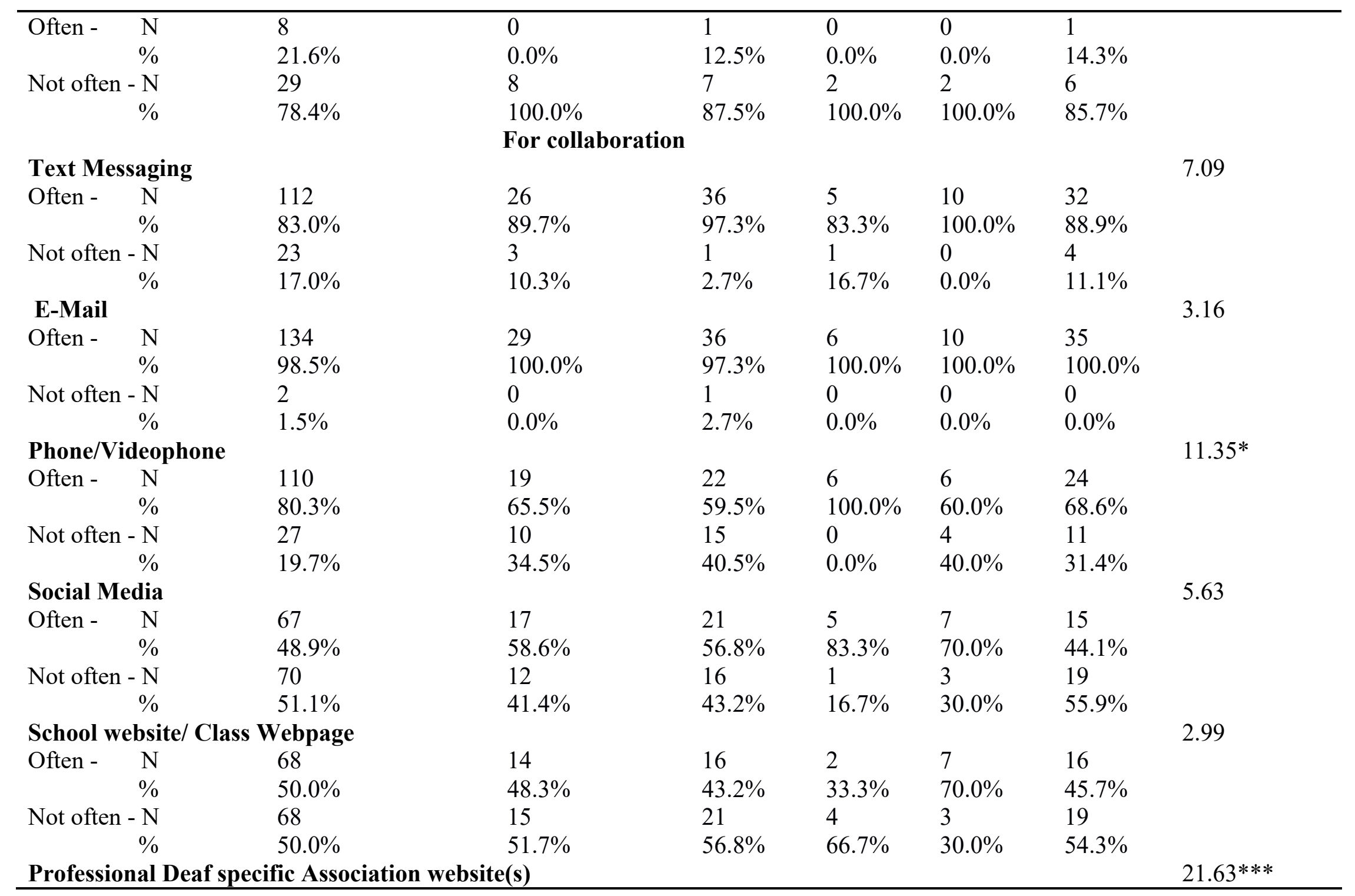




\begin{tabular}{|c|c|c|c|c|c|c|c|}
\hline \multirow[t]{2}{*}{ Often - } & 50 & 16 & 20 & 3 & 9 & 8 & \\
\hline & $37.0 \%$ & $55.2 \%$ & $57.1 \%$ & $50.0 \%$ & $90.0 \%$ & $22.9 \%$ & \\
\hline Not often - N & 85 & 13 & 15 & 3 & 1 & 27 & \\
\hline$\%$ & $63.0 \%$ & $44.8 \%$ & $42.9 \%$ & $50.0 \%$ & $10.0 \%$ & $77.1 \%$ & \\
\hline \multicolumn{3}{|c|}{ Organizational Websites } & & & & & 1.48 \\
\hline \multirow[t]{2}{*}{ Often - } & 102 & 21 & 27 & 5 & 6 & 27 & \\
\hline & $74.5 \%$ & $72.4 \%$ & $75.0 \%$ & $83.3 \%$ & $60.0 \%$ & $75.0 \%$ & \\
\hline Not often - N & 35 & 8 & 9 & 1 & 4 & 9 & \\
\hline$\%$ & $25.5 \%$ & $27.6 \%$ & $25.0 \%$ & $16.7 \%$ & $40.0 \%$ & $25.0 \%$ & \\
\hline \multicolumn{3}{|c|}{ Presentation software } & & & & & 3.06 \\
\hline \multirow[t]{2}{*}{ Often - } & 98 & 17 & 25 & 4 & 7 & 22 & \\
\hline & $71.5 \%$ & $58.6 \%$ & $69.4 \%$ & $66.7 \%$ & $70.0 \%$ & $61.1 \%$ & \\
\hline Not often - N & 39 & 12 & 11 & 2 & 3 & 14 & \\
\hline$\%$ & $28.5 \%$ & $41.4 \%$ & $30.6 \%$ & $33.3 \%$ & $30.0 \%$ & $38.9 \%$ & \\
\hline \multicolumn{2}{|c|}{ Word Processing } & & & & & & 4.92 \\
\hline \multirow[t]{2}{*}{ Often - } & 114 & 21 & 31 & 5 & 10 & 29 & \\
\hline & $83.2 \%$ & $72.4 \%$ & $88.6 \%$ & $83.3 \%$ & $100.0 \%$ & $80.6 \%$ & \\
\hline Not often - N & 23 & 8 & 4 & 1 & 0 & 7 & \\
\hline$\%$ & $16.8 \%$ & $27.6 \%$ & $11.4 \%$ & $16.7 \%$ & $0.0 \%$ & $19.4 \%$ & \\
\hline \multicolumn{2}{|l|}{ Other } & & & & & & 8.18 \\
\hline \multirow[t]{2}{*}{ Often - } & 13 & 1 & 1 & 0 & 3 & 1 & \\
\hline & $41.9 \%$ & $12.5 \%$ & $14.3 \%$ & $0.0 \%$ & $75.0 \%$ & $12.5 \%$ & \\
\hline Not often - N & 18 & 7 & 6 & 2 & 1 & 7 & \\
\hline$\%$ & $58.1 \%$ & $87.5 \%$ & $85.7 \%$ & $100.0 \%$ & $25.0 \%$ & $87.5 \%$ & \\
\hline
\end{tabular}


The results indicate that itinerant teachers of $\mathrm{d} / \mathrm{hh}$ students were more likely to use a smart phone for communication. While, itinerant teachers were less likely to use an overhead projector for communication, those teachers of $\mathrm{d} / \mathrm{hh}$ students in two or more academic levels were more likely to do so. Itinerant teachers were less likely to use a whiteboard for communication, while those teachers of $\mathrm{d} / \mathrm{h}$ students, employed in schools for the deaf, were more likely to use whiteboards for communication. Itinerants were more likely to use captioning for communication while those teaching in schools for the deaf were less likely. While itinerant teachers were less likely to use phone/video phone for collaboration, those teachers in schools for the deaf reported being more likely to use a phone/video phone. Those in two or more academic levels were more likely to use a deaf association website for collaboration while those in other settings were less likely to do so for collaboration.

Then, the researcher examined the relationship between technology use for communication and collaboration and the location in which the teacher works (see Table 8.) Where a significant relationship emerged, the researcher examined the adjusted standardized residuals to identify what was driving the significant finding.

Table 8 Chi-square analysis of relationship between using technology for communication and collaboration and the geographic location of the teacher.

\begin{tabular}{|c|c|c|c|c|}
\hline Technology & Urban & Suburban & Rural & \\
\hline & For & & & Fisher's exact \\
\hline Laptop & & & & .17 \\
\hline Often - & 72 & 77 & 33 & \\
\hline$\%$ & $75.8 \%$ & $77.8 \%$ & $78.6 \%$ & \\
\hline Not often - N & 23 & 22 & 9 & \\
\hline$\%$ & $24.2 \%$ & $22.2 \%$ & $21.4 \%$ & \\
\hline iPad or tablet & & & & 3.20 \\
\hline Often - & 79 & 74 & 32 & \\
\hline$\%$ & $84.0 \%$ & $75.5 \%$ & $72.7 \%$ & \\
\hline Not often $-\mathrm{N}$ & 15 & 24 & 12 & \\
\hline
\end{tabular}




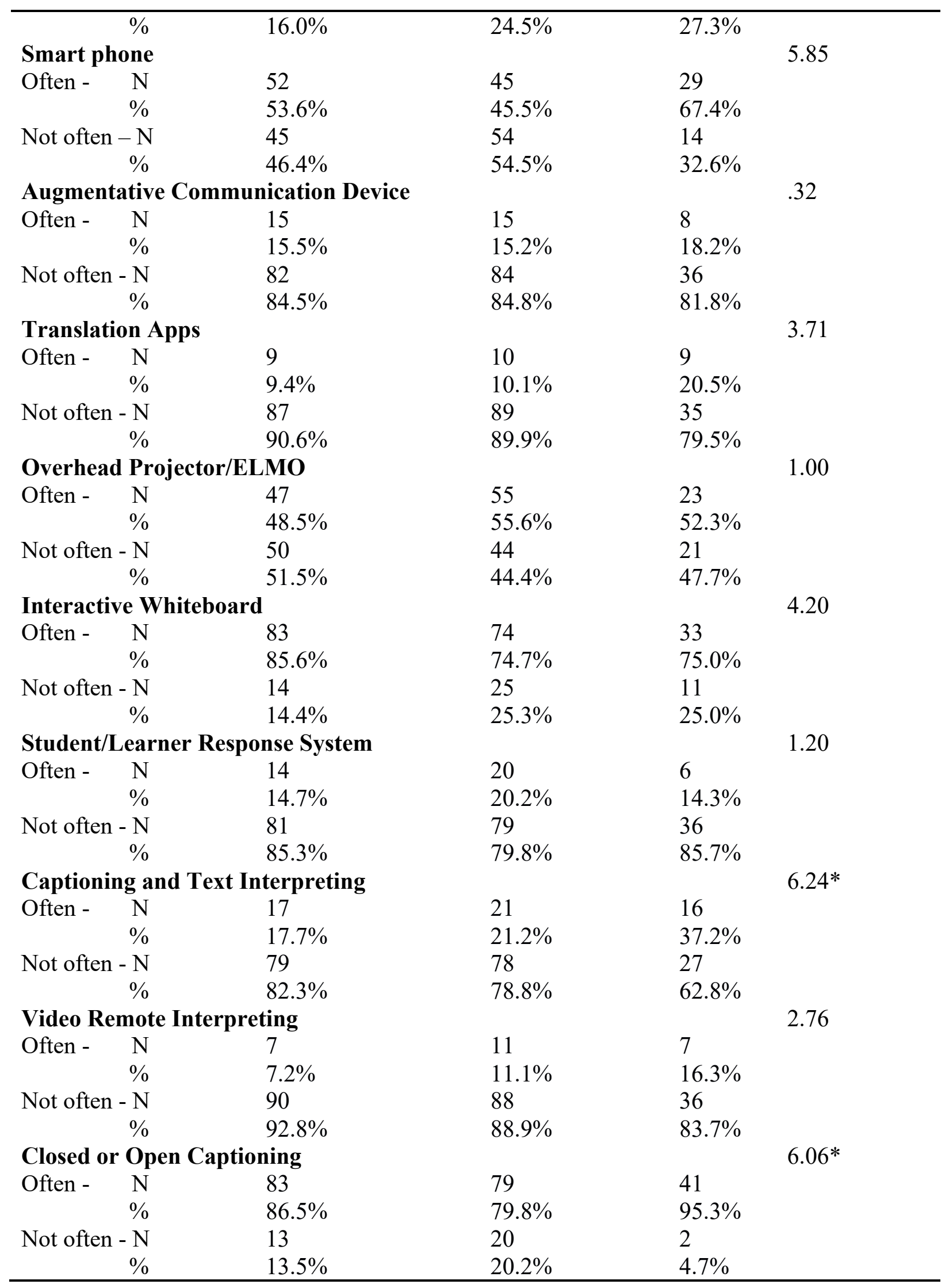




\begin{tabular}{|c|c|c|c|c|}
\hline \multicolumn{4}{|l|}{ Other } & \multirow[t]{3}{*}{4.18} \\
\hline \multirow[t]{2}{*}{ Often - } & 3 & 2 & 4 & \\
\hline & $12.5 \%$ & $8.3 \%$ & $36.4 \%$ & \\
\hline Not often - N & 21 & 22 & 7 & \\
\hline \multirow[t]{2}{*}{$\%$} & $87.5 \%$ & $91.7 \%$ & $63.6 \%$ & \\
\hline & \multicolumn{2}{|c|}{ For collaboration } & & \\
\hline \multicolumn{4}{|c|}{ Text Messaging } & 1.80 \\
\hline \multirow[t]{2}{*}{ Often - } & 82 & 84 & 41 & \\
\hline & $87.2 \%$ & $84.8 \%$ & $93.2 \%$ & \\
\hline Not often - N & 12 & 15 & 3 & \\
\hline$\%$ & $12.8 \%$ & $15.2 \%$ & $6.8 \%$ & \\
\hline E-Mail & & & & .88 \\
\hline \multirow[t]{2}{*}{ Often - } & 92 & 98 & 44 & \\
\hline & $97.9 \%$ & $99.0 \%$ & $100.0 \%$ & \\
\hline Not often - N & 2 & 1 & 0 & \\
\hline$\%$ & $2.1 \%$ & $1.0 \%$ & $0.0 \%$ & \\
\hline \multicolumn{2}{|c|}{ Phone/Videophone } & & & .03 \\
\hline \multirow{2}{*}{ Often - } & 71 & 73 & 32 & \\
\hline & $74.0 \%$ & $73.7 \%$ & $74.4 \%$ & \\
\hline Not often - N & 25 & 26 & 11 & \\
\hline$\%$ & $26.0 \%$ & $26.3 \%$ & $25.6 \%$ & \\
\hline \multicolumn{3}{|l|}{ Social Media } & & .15 \\
\hline \multirow[t]{2}{*}{ Often - } & 52 & 52 & 24 & \\
\hline & $54.2 \%$ & $52.5 \%$ & $55.8 \%$ & \\
\hline Not often - N & 44 & 47 & 19 & \\
\hline$\%$ & $45.8 \%$ & $47.5 \%$ & $44.2 \%$ & \\
\hline \multicolumn{3}{|c|}{ School website/ Class Webpage } & & 2.14 \\
\hline \multirow[t]{2}{*}{ Often - } & 42 & 53 & 22 & \\
\hline & $43.8 \%$ & $54.1 \%$ & $51.2 \%$ & \\
\hline Not often - N & 54 & 45 & 21 & \\
\hline$\%$ & $56.3 \%$ & $45.9 \%$ & $48.8 \%$ & \\
\hline \multicolumn{3}{|c|}{ Professional Deaf specific Association website(s) } & & 3.77 \\
\hline \multirow[t]{2}{*}{ Often - } & 42 & 36 & 23 & \\
\hline & $44.2 \%$ & $37.1 \%$ & $54.8 \%$ & \\
\hline Not often - N & 53 & 61 & 19 & \\
\hline$\%$ & $55.8 \%$ & $62.9 \%$ & $45.2 \%$ & \\
\hline Organization & & & & .73 \\
\hline Often - & 70 & 75 & 31 & \\
\hline$\%$ & $72.9 \%$ & $76.5 \%$ & $70.5 \%$ & \\
\hline Not often - N & 26 & 23 & 13 & \\
\hline$\%$ & $27.1 \%$ & $23.5 \%$ & $29.5 \%$ & \\
\hline Presentation & & & & 3.19 \\
\hline Often - & 69 & 62 & 34 & \\
\hline$\%$ & $71.9 \%$ & $63.3 \%$ & $77.3 \%$ & \\
\hline Not often - N & 27 & 36 & 10 & \\
\hline$\%$ & $28.1 \%$ & $36.7 \%$ & $22.7 \%$ & \\
\hline
\end{tabular}




\begin{tabular}{|c|c|c|c|c|}
\hline \multicolumn{4}{|c|}{ Word Processing } & \multirow[t]{3}{*}{$6.01^{*}$} \\
\hline Often - & 80 & 78 & 41 & \\
\hline$\%$ & $83.3 \%$ & $79.6 \%$ & $95.3 \%$ & \\
\hline Not often - N & 16 & 20 & 2 & \\
\hline$\%$ & $16.7 \%$ & $20.4 \%$ & $4.7 \%$ & \\
\hline Other & & & & 1.36 \\
\hline Often - & 6 & 9 & 3 & \\
\hline$\%$ & $25.0 \%$ & $37.5 \%$ & $42.9 \%$ & \\
\hline Not often - N & 18 & 15 & 4 & \\
\hline$\%$ & $75.0 \%$ & $62.5 \%$ & $57.1 \%$ & \\
\hline
\end{tabular}

These results indicated that those teachers of $\mathrm{d} / \mathrm{hh}$ students teaching in rural locations were more likely to use captioning and text interpreting for communication than those teaching in other locations. The data also supports that those teachers of $\mathrm{d} / \mathrm{hh}$ students in rural settings were more likely to use closed or open captioning for communication and those in suburban settings were less likely to do so. Also, those teachers in rural settings were more likely to use word processing for collaboration than those in other settings.

Then, the researcher examined the relationship between technology use for communication and collaboration and the educational level of students taught. Because of small expected cell counts, Fisher's exact test was used to test for the relationship (see Table 9). Where a significant relationship emerged, the researcher examined the adjusted standardized residuals to identify what was driving the significant findings. 
Table 9.

Chi-square analysis of relationship between using technology for communication and collaboration and the level of students taught.

\begin{tabular}{|c|c|c|c|c|c|c|c|}
\hline Technology & Pre-K & Elementary & Secondary & Post-secondary & $\begin{array}{l}\text { Two or } \\
\text { more }\end{array}$ & Other & \\
\hline & & For con & unication & & & & Fisher's exact \\
\hline Laptop & & & & & & & $14.99 * *$ \\
\hline Often - & 13 & 40 & 55 & 4 & 67 & 21 & \\
\hline$\%$ & $56.5 \%$ & $71.4 \%$ & $76.4 \%$ & $57.1 \%$ & $89.3 \%$ & $75.0 \%$ & \\
\hline Not often - N & 10 & 16 & 17 & 3 & 8 & 7 & \\
\hline$\%$ & $43.5 \%$ & $28.6 \%$ & $23.6 \%$ & $42.9 \%$ & $10.7 \%$ & $25.0 \%$ & \\
\hline iPad or tablet & & & & & & & $15.50 * *$ \\
\hline Often - $\quad \mathrm{N}$ & 17 & 47 & 49 & 4 & 67 & 24 & \\
\hline$\%$ & $73.9 \%$ & $85.5 \%$ & $67.1 \%$ & $57.1 \%$ & $89.3 \%$ & $85.7 \%$ & \\
\hline Not often $-\mathrm{N}$ & 6 & 8 & 24 & 3 & 8 & 4 & \\
\hline$\%$ & $26.1 \%$ & $14.5 \%$ & $32.9 \%$ & $42.9 \%$ & $10.7 \%$ & $14.3 \%$ & \\
\hline Smart phone & & & & & & & $16.50 * *$ \\
\hline Often - & 9 & 23 & 38 & 3 & 53 & 12 & \\
\hline$\%$ & $39.1 \%$ & $40.4 \%$ & $51.4 \%$ & $42.9 \%$ & $70.7 \%$ & $42.9 \%$ & \\
\hline Not often $-\mathrm{N}$ & 14 & 34 & 36 & 4 & 22 & 16 & \\
\hline$\%$ & $60.9 \%$ & $59.6 \%$ & $48.6 \%$ & $57.1 \%$ & $29.3 \%$ & $57.1 \%$ & \\
\hline Augmentative Con & cation D & & & & & & 4.35 \\
\hline Often - & 4 & 10 & 7 & 1 & 16 & 5 & \\
\hline$\%$ & $17.4 \%$ & $17.5 \%$ & $9.5 \%$ & $14.3 \%$ & $21.1 \%$ & $17.9 \%$ & \\
\hline Not often - N & 19 & 47 & 67 & 6 & 60 & 23 & \\
\hline$\%$ & $82.6 \%$ & $82.5 \%$ & $90.5 \%$ & $85.7 \%$ & $78.9 \%$ & $82.1 \%$ & \\
\hline Translation Apps & & & & & & & 5.34 \\
\hline Often - & 1 & 5 & 7 & 0 & 14 & 4 & \\
\hline$\%$ & $4.3 \%$ & $8.8 \%$ & $9.5 \%$ & $0.0 \%$ & $18.7 \%$ & $14.3 \%$ & \\
\hline Not often - N & 22 & 52 & 67 & 7 & 61 & 24 & \\
\hline
\end{tabular}




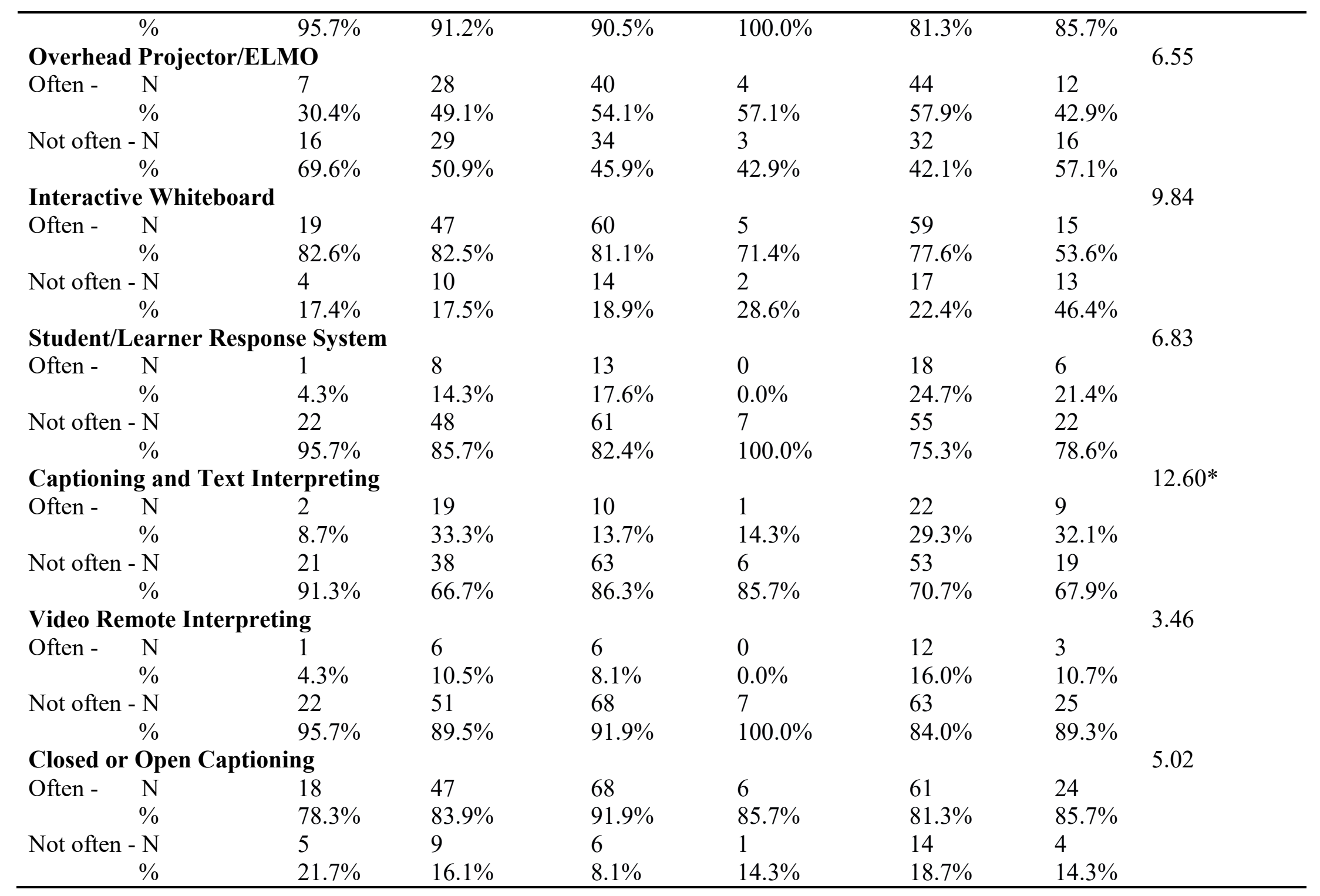




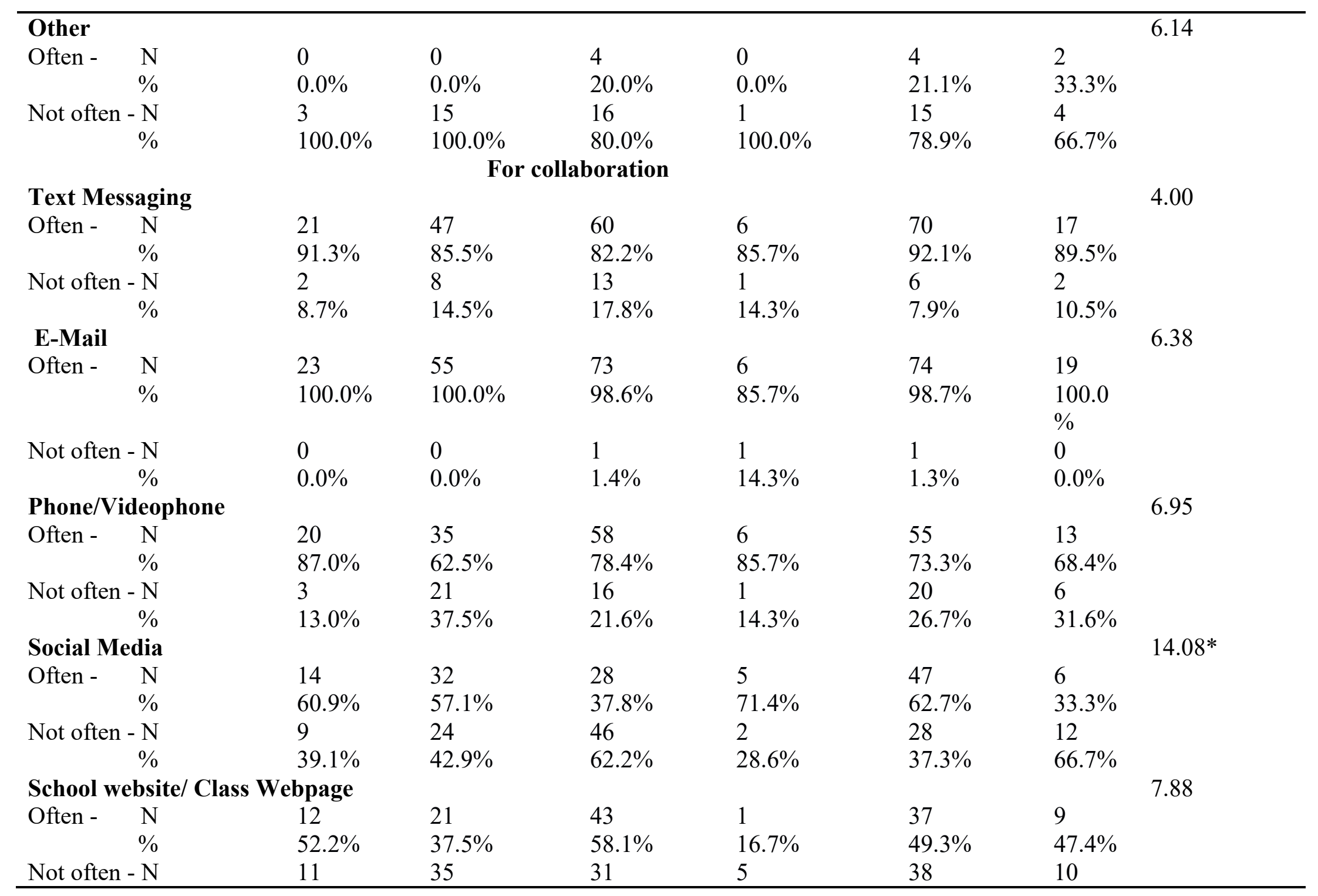




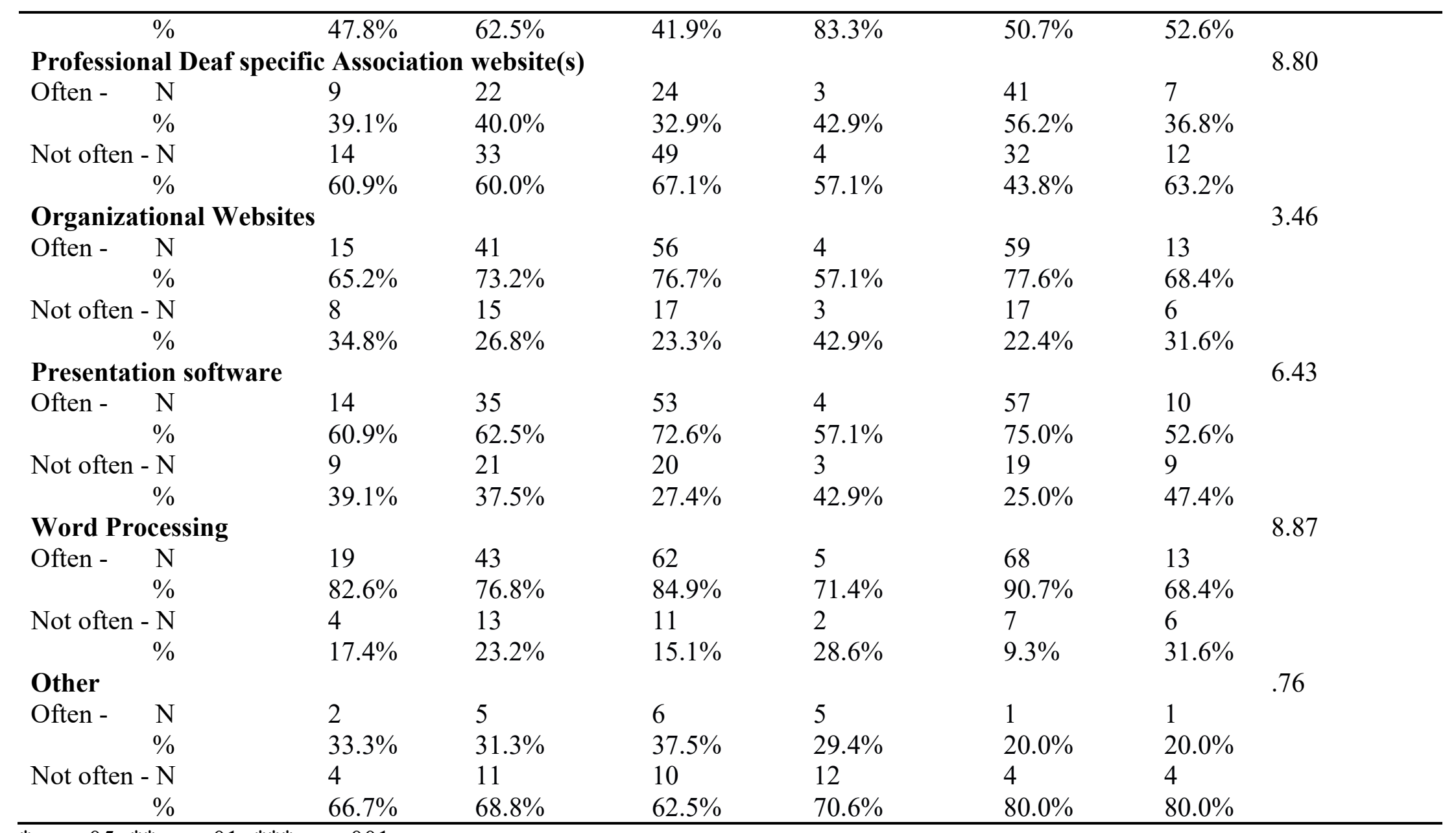

$* p<.05 ; * * p<.01 ; * * * p<.001$ 
These results reveal that teachers in pre-K schools were less likely to use a laptop computer for communication, whereas teachers instructing students in two or more educational levels (e.g. PreK and middle school) reported using a laptop computer for communication. Teachers in secondary school reported being less likely to use iPads or other types of tablets for communication, whereas, teachers instructing in two or more academic levels were more likely to use iPads or other types of tablets for communication.

Teachers in elementary school reported being less likely to use smart phones for communication. Teachers in two or more grade levels reported being more likely to use smart phones for communication. Teachers in secondary school were less likely to use captioning for communication and also reported being less likely to use social media for collaboration. However, teachers in two or more grade levels reported being more likely to use social media for collaboration.

\section{Research Question 2b: Technology for Communication and Additional Training}

In order to examine if there a relationship between use of technology for student communication and collaboration and use of technology for obtaining additional training, the researcher conducted chi-square analysis (Table 10). Where a significant relationship emerged, the researcher examined the adjusted standardized residuals to identify what was driving the significant findings. 
Table 10.

Chi square analysis of relationship between use of technology for additional training and use of technology for communication and collaboration.

\begin{tabular}{|c|c|c|c|}
\hline Technology & $\begin{array}{l}\text { Uses technology for } \\
\text { training }\end{array}$ & $\begin{array}{l}\text { Does not use technology } \\
\text { for training }\end{array}$ & \\
\hline \multicolumn{3}{|c|}{ For communication } & $X^{2}(d f)$ \\
\hline \multicolumn{3}{|c|}{ Laptop } & $1.67(1)$ \\
\hline \multirow[t]{2}{*}{ Often - } & 61 & 139 & \\
\hline & $71.8 \%$ & $79.0 \%$ & \\
\hline Not often - N & 24 & 37 & \\
\hline$\%$ & $28.2 \%$ & $21.0 \%$ & \\
\hline \multicolumn{2}{|l|}{ iPad or tablet } & & $.01(1)$ \\
\hline \multirow[t]{2}{*}{ Often - } & 68 & 140 & \\
\hline & $80.0 \%$ & $79.5 \%$ & \\
\hline Not often $-\mathrm{N}$ & 17 & 36 & \\
\hline$\%$ & $20.0 \%$ & $20.5 \%$ & \\
\hline \multicolumn{2}{|l|}{ Smart phone } & & $.00(1)$ \\
\hline \multirow[t]{2}{*}{ Often - } & 45 & 93 & \\
\hline & $52.3 \%$ & $52.2 \%$ & \\
\hline Not often $-\mathrm{N}$ & 41 & 85 & \\
\hline$\%$ & $47.7 \%$ & $47.8 \%$ & \\
\hline \multicolumn{3}{|c|}{ Augmentative Communication Device } & $1.17(1)$ \\
\hline \multirow{2}{*}{ Often - } & 17 & 26 & \\
\hline & $19.8 \%$ & $14.5 \%$ & \\
\hline Not often - N & 69 & 153 & \\
\hline$\%$ & $80.2 \%$ & $85.5 \%$ & \\
\hline \multicolumn{2}{|c|}{ Translation Apps } & & $.20(1)$ \\
\hline \multirow[t]{2}{*}{ Often - } & 9 & 22 & \\
\hline & $10.5 \%$ & $12.4 \%$ & \\
\hline Not often - N & 77 & 156 & \\
\hline$\%$ & $89.5 \%$ & $87.6 \%$ & \\
\hline \multicolumn{2}{|c|}{ Overhead Projector/ELMO } & & $1.60(1)$ \\
\hline \multirow[t]{2}{*}{ Often - } & 39 & 96 & \\
\hline & $45.3 \%$ & $53.6 \%$ & \\
\hline Not often - N & 47 & 83 & \\
\hline$\%$ & $54.7 \%$ & $46.4 \%$ & \\
\hline \multicolumn{2}{|c|}{ Interactive Whiteboard } & & $10.89(1)^{* *}$ \\
\hline \multirow[t]{2}{*}{ Often - } & 56 & 149 & \\
\hline & $65.1 \%$ & $83.2 \%$ & \\
\hline Not often - N & 30 & 30 & \\
\hline$\%$ & $34.9 \%$ & $16.8 \%$ & \\
\hline \multicolumn{2}{|c|}{ Student/Learner Response System } & & $.39(1)$ \\
\hline Often - & 13 & 33 & \\
\hline$\%$ & $15.5 \%$ & $18.6 \%$ & \\
\hline
\end{tabular}




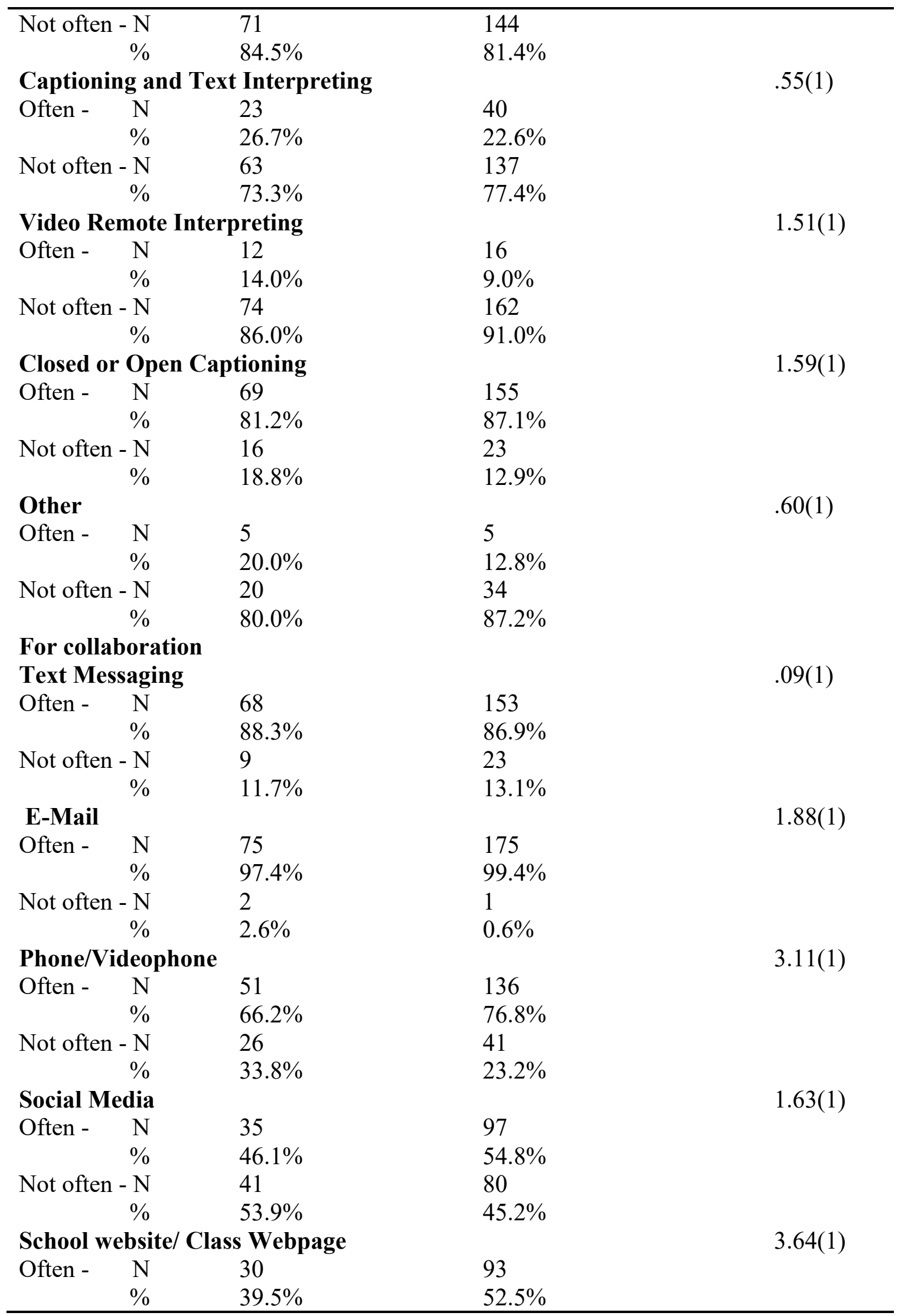




\begin{tabular}{|c|c|c|c|}
\hline Not often - N & 46 & 84 & \\
\hline$\%$ & $60.5 \%$ & $47.5 \%$ & \\
\hline \multicolumn{3}{|c|}{$\begin{array}{l}\text { Professional Deaf specific Association } \\
\text { website(s) }\end{array}$} & $.01(1)$ \\
\hline \multirow[t]{2}{*}{ Often - } & 33 & 73 & \\
\hline & $42.9 \%$ & $42.2 \%$ & \\
\hline Not often - N & 44 & 100 & \\
\hline$\%$ & $57.1 \%$ & $57.8 \%$ & \\
\hline \multicolumn{3}{|c|}{ Organizational Websites } & $.87(1)$ \\
\hline \multirow[t]{2}{*}{ Often - } & 54 & 134 & \\
\hline & $70.1 \%$ & $75.7 \%$ & \\
\hline Not often - N & 23 & 43 & \\
\hline$\%$ & $29.9 \%$ & $24.3 \%$ & \\
\hline \multicolumn{3}{|c|}{ Presentation software } & $2.54(1)$ \\
\hline \multirow[t]{2}{*}{ Often - } & 47 & 126 & \\
\hline & $61.0 \%$ & $71.2 \%$ & \\
\hline Not often - N & 30 & 51 & \\
\hline$\%$ & $39.0 \%$ & $28.8 \%$ & \\
\hline \multicolumn{3}{|c|}{ Word Processing } & $4.63(1)^{*}$ \\
\hline \multirow[t]{2}{*}{ Often - } & 58 & 152 & \\
\hline & $75.3 \%$ & $86.4 \%$ & \\
\hline Not often - N & 19 & 24 & \\
\hline$\%$ & $24.7 \%$ & $13.6 \%$ & \\
\hline \multicolumn{2}{|l|}{ Other } & & $.14(1)$ \\
\hline \multirow[t]{2}{*}{ Often - } & 6 & 13 & \\
\hline & $28.6 \%$ & $33.3 \%$ & \\
\hline Not often - N & 15 & 26 & \\
\hline$\%$ & $71.4 \%$ & $66.7 \%$ & \\
\hline
\end{tabular}

The results of indicated that those who use technology for training were less likely to use an interactive white board for communication and less likely to use word processing for collaboration.

\section{Research Question 3: Professional Development and Job Position}

To examine if there is a relationship between use of technology for additional training and job position including: setting, geographic location, and academic level, the researcher conducted chi-square analysis. First, the researcher examined the relationship between the use of technology for additional training and the setting in which the teacher 
currently works (see Table 11). Due to small expected cell counts, Fisher's exact test was used to test the relationships.

Table 11.

Chi-square analysis of relationship between use of technology for additional training and setting in which teacher works.

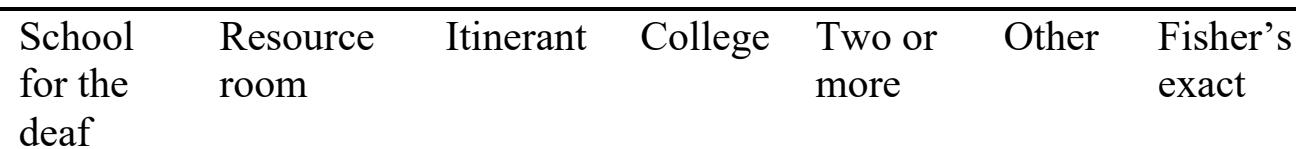

\begin{tabular}{|c|c|c|c|c|c|c|c|}
\hline \multicolumn{7}{|c|}{ Uses technology for training } & \multirow[t]{3}{*}{$186.51 * * *$} \\
\hline $\mathrm{N}$ & 22 & 11 & 20 & 3 & 0 & 134 & \\
\hline$\%$ & $16.1 \%$ & $37.9 \%$ & $54.1 \%$ & $50.0 \%$ & $0.0 \%$ & $89.3 \%$ & \\
\hline \multicolumn{8}{|c|}{ Does not use technology for training } \\
\hline $\mathrm{N}$ & 115 & 18 & 17 & 3 & 10 & 16 & \\
\hline$\%$ & $83.9 \%$ & $62.1 \%$ & $45.9 \%$ & $50.0 \%$ & $100.0 \%$ & $10.7 \%$ & \\
\hline
\end{tabular}

Those teachers employed in schools for the deaf and those employed in two or more academic levels reported being less likely to use technology for training. Those employed in settings other than a school for the deaf reported being more likely to use technology for training than not.

Next, the researcher examined the relationship between use of technology for additional training and the geographic environment in which the teacher currently works (see Table 12).

Table 12.

Chi-square analysis of relationship between use of technology for additional training and geographic environment.

\begin{tabular}{ccccc}
\hline & Urban & Suburban & Rural & $X^{2}(d f)$ \\
\hline \multicolumn{1}{l}{ Uses technology for training } & & & $1.54(1)$ \\
$\mathrm{N}$ & 26 & 22 & 14 & \\
$\%$ & $26.8 \%$ & $22.2 \%$ & $31.8 \%$ & \\
Does not use technology for training & & & \\
$\mathrm{N}$ & 71 & 77 & 30 & \\
$\%$ & $73.2 \%$ & $77.8 \%$ & $68.2 \%$ & \\
$* p<.05 ; * *$ & $<<.01 ; * * p<.001$ & & &
\end{tabular}


There was no significant relationship between use of technology for additional training and the geographic environment in which the teacher currently works.

Finally, the researcher examined the relationship between use of technology for additional training and the academic level of students taught (see Table 13).

Table 13.

Chi-square analysis of relationship between use of technology for additional training and level of students taught.

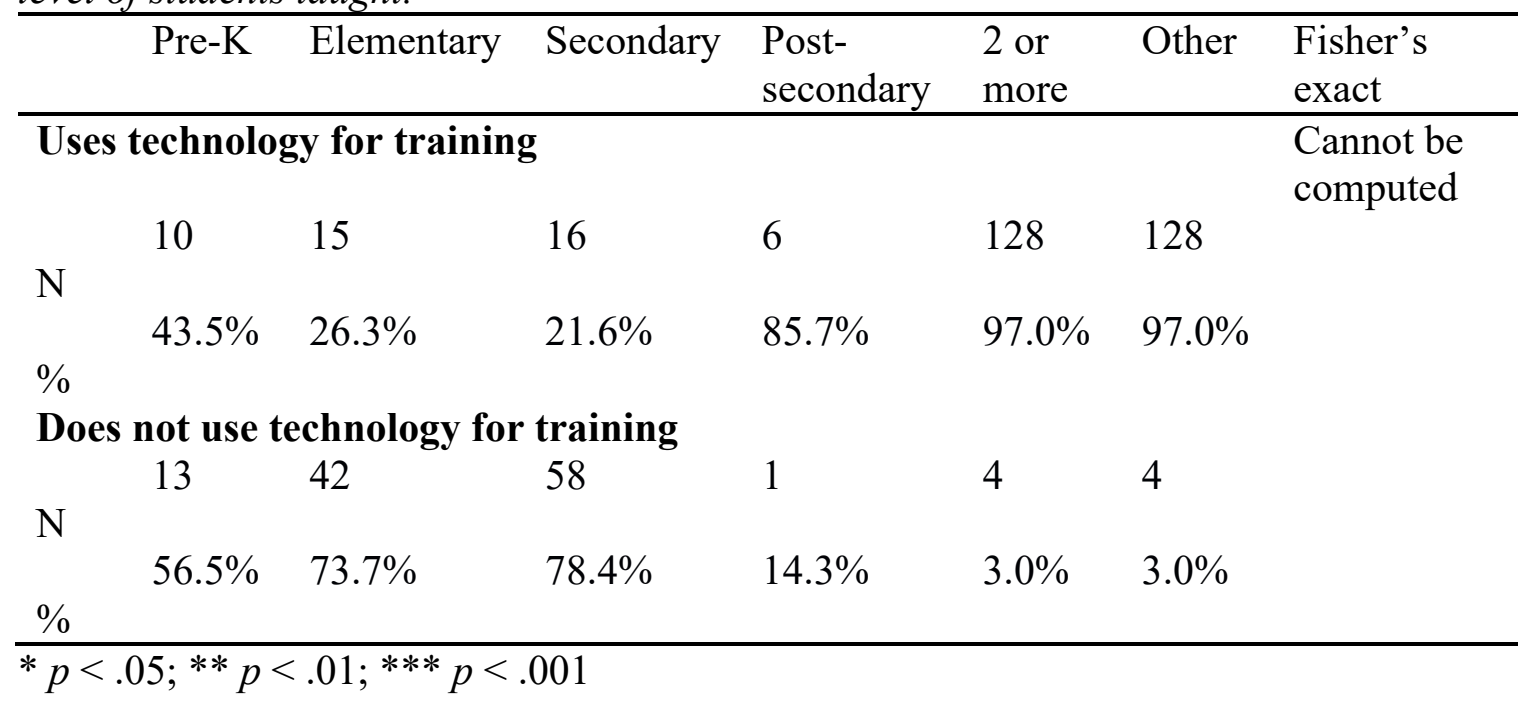

However, the cell sizes were too small to do a chi-square analysis. The calculation of the Fisher's Exact failed to converge.

\section{Research Question 3a: Employer Provided Disability Specific Technology Training}

To examine if there a relationship between use of technology and frequency of disability specific, employer-provided, professional development in the use of technology with $\mathrm{d} / \mathrm{hh}$ students, the researcher calculated Spearman's rank correlation coefficient/Spearman's rho (see Table 14).

Table 14.

Correlations between use of technology frequency of employer-provided professional development in the use of instructional technology.

\begin{tabular}{lll}
\hline Technology & $\mathrm{N}$ & Spearman Rho coefficient \\
\hline For design & & \\
Writing/Document software & 191 & .08 \\
\hline
\end{tabular}




\begin{tabular}{|c|c|c|}
\hline Presentation software & 192 & $.14^{*}$ \\
\hline Spreadsheet software & 189 & .06 \\
\hline Video editing software & 191 & .00 \\
\hline Photo editing software & 192 & .04 \\
\hline Other & 87 & .20 \\
\hline \multicolumn{3}{|l|}{ For delivery } \\
\hline Text Messaging & 192 & .04 \\
\hline Email & 192 & .13 \\
\hline Phone/Videophone & 191 & .01 \\
\hline Social Media & 192 & .09 \\
\hline Search Engines & 193 & .02 \\
\hline Word Processing & 193 & .01 \\
\hline Education Apps & 192 & .13 \\
\hline Posting Videos, Vlogs & 190 & .04 \\
\hline Educational Videos & 191 & .01 \\
\hline Academic Services & 192 & .00 \\
\hline News/information website & 191 & .08 \\
\hline ASL Dictionary & 192 & .00 \\
\hline Virtual Immersion & 189 & .02 \\
\hline Learning Management System & 192 & $.18^{*}$ \\
\hline Virtual Assistants/Agents & 190 & .10 \\
\hline Podcasts/Vodcasts & 190 & .01 \\
\hline Educational services & 193 & .00 \\
\hline \multicolumn{3}{|l|}{ For communication } \\
\hline Laptop & 191 & .03 \\
\hline iPad or Tablet & 189 & .02 \\
\hline Smart Phone & 192 & .04 \\
\hline Augmentative Communication Device & 193 & .02 \\
\hline Translation Apps & 192 & .07 \\
\hline Overhead Projector/ELMO & 193 & .01 \\
\hline Interactive Whiteboard & 193 & .13 \\
\hline Student/Learner Response System & 191 & .10 \\
\hline Captioning and Text Interpreting & 191 & .09 \\
\hline Video Remote Interpreting & 192 & .03 \\
\hline Closed or Open Captioning & 191 & .07 \\
\hline Other & 45 & .15 \\
\hline \multicolumn{3}{|l|}{ For collaboration } \\
\hline Text Messaging & 191 & .07 \\
\hline E-Mail & 192 & $.15^{*}$ \\
\hline Phone/Videophone & 192 & $.17^{*}$ \\
\hline Social Media & 192 & .09 \\
\hline School website/ Class Webpage & 192 & $.24^{* *}$ \\
\hline Professional Deaf specific Association website(s) & 188 & $.16^{*}$ \\
\hline Organizational Websites & 192 & .14 \\
\hline Presentation software & 192 & $.14^{*}$ \\
\hline Word Processing & 191 & $.16^{*}$ \\
\hline
\end{tabular}




\begin{tabular}{lll}
\hline Other & 43 & $.38^{*}$ \\
\hline$* p<.05 ; * * p<.01 ; * * * p<.001$ &
\end{tabular}

The results indicated that more frequent employer-provided professional development in the use of technology was associated with more frequent use of presentation software for design, leaning management systems for delivery, email for collaboration, phone/videophone for collaboration, school website for collaboration, professional deaf association website for collaboration, presentation software for collaboration, word processing for collaboration, and other technologies for collaboration.

\section{Research Question 4: Challenges}

To examine how often teachers of $\mathrm{d} / \mathrm{hh}$ students face challenges related to technology, the researcher calculated basic frequencies (see Table 15).

Table 15.

Frequency of challenges faced by teachers of deaf/hh students.

\begin{tabular}{llll}
\hline Challenges & $\mathrm{N}$ & \% Often & \% Not often \\
\hline Hardware absent or outdated & 240 & 65.4 & 34.6 \\
Software absent or outdated & 240 & 68.3 & 31.7 \\
No internet Access & 240 & 34.2 & 65.8 \\
No WIFI Access & 241 & 39.0 & 61.0 \\
No or inadequate training & 241 & 61.4 & 38.6 \\
No or inadequate funding & 239 & 66.5 & 33.5 \\
Fear of using new technology & 240 & 22.9 & 77.1 \\
Lack of time for training or practice & 240 & 73.8 & 26.3 \\
Student literacy level & 239 & 79.1 & 20.9 \\
Student disinterest or resistance & 238 & 30.3 & 69.7 \\
Family disinterest or resistance & 238 & 43.7 & 56.3 \\
Other & 49 & 26.5 & 73.5 \\
\hline
\end{tabular}

The challenges reported by teachers of $\mathrm{d} / \mathrm{hh}$ students included, in order of frequency: student literacy level, lack of time for training or practice, software was absent or outdated, lack of funding or inadequate funding, hardware was absent or outdated, and 
lack of training or inadequate training offered. Teachers of $\mathrm{d} / \mathrm{hh}$ students reported less often that they had challenges getting access to the internet or WiFi. They also reported less often on challenges related to the fear of using new technology or of student disinterest or resistance using technology.

\section{Research Question 4a: Job position}

To examine research question 4a: is there a relationship between the challenges experienced by teachers of $\mathrm{d} / \mathrm{hh}$ students and their job position including: instructional setting, geographic location, and academic level, the researcher conducted chi-square analysis. First, the researcher examined the relationship between frequency of challenges faced and the setting in which the teacher currently works (see Table 16). Because of small expected cell counts, Fisher's exact test was used to test the relationships. Where a significant relationship emerged, the researcher examined the adjusted standardized residuals to identify what was driving the significant findings. 
Table 16.

Chi-square analysis of relationship between frequency of challenges faced and setting in which teacher works.

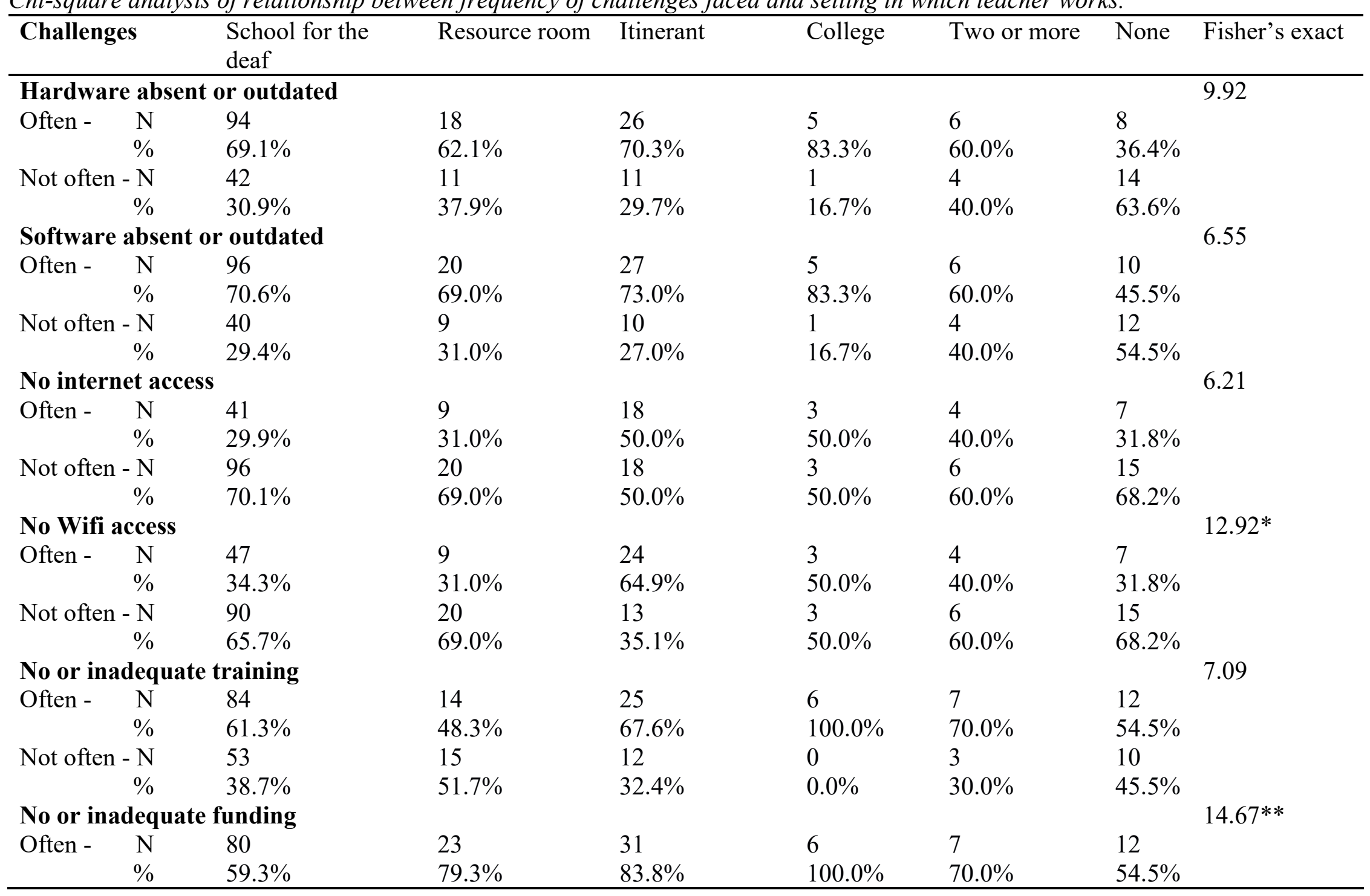




\begin{tabular}{|c|c|c|c|c|c|c|c|}
\hline Not often - N & 55 & 6 & 6 & 0 & 3 & 10 & \\
\hline$\%$ & $40.7 \%$ & $20.7 \%$ & $16.2 \%$ & $0.0 \%$ & $30.0 \%$ & $45.5 \%$ & \\
\hline \multicolumn{7}{|c|}{ Fear of using new technology } & 8.01 \\
\hline \multirow[t]{2}{*}{ Often - } & 28 & 3 & 12 & 1 & 2 & 9 & \\
\hline & $20.6 \%$ & $10.7 \%$ & $32.4 \%$ & $16.7 \%$ & $20.0 \%$ & $39.1 \%$ & \\
\hline Not often - N & 108 & 25 & 25 & 5 & 8 & 14 & \\
\hline$\%$ & $79.4 \%$ & $89.3 \%$ & $67.6 \%$ & $83.3 \%$ & $80.0 \%$ & $60.9 \%$ & \\
\hline \multicolumn{4}{|c|}{ Lack of time for training or practice } & & & & 5.11 \\
\hline \multirow[t]{2}{*}{ Often - } & 102 & 18 & 28 & 6 & 8 & 15 & \\
\hline & $75.6 \%$ & $62.1 \%$ & $75.7 \%$ & $100.0 \%$ & $80.0 \%$ & $65.2 \%$ & \\
\hline Not often - N & 33 & 11 & 9 & 0 & 2 & 8 & \\
\hline$\%$ & $24.4 \%$ & $37.9 \%$ & $24.3 \%$ & $0.0 \%$ & $20.0 \%$ & $34.8 \%$ & \\
\hline \multicolumn{3}{|c|}{ Student literacy level } & & & & & 4.02 \\
\hline \multirow[t]{2}{*}{ Often - } & 111 & 20 & 27 & 5 & 7 & 19 & \\
\hline & $82.2 \%$ & $69.0 \%$ & $75.0 \%$ & $83.3 \%$ & $70.0 \%$ & $82.6 \%$ & \\
\hline Not often - N & 24 & 9 & 9 & 1 & 3 & 4 & \\
\hline$\%$ & $17.8 \%$ & $31.0 \%$ & $25.0 \%$ & $16.7 \%$ & $30.0 \%$ & $17.4 \%$ & \\
\hline \multicolumn{3}{|c|}{ Student disinterest or resistance } & & & & & 9.42 \\
\hline \multirow[t]{2}{*}{ Often - } & 39 & 4 & 17 & 3 & 3 & 6 & \\
\hline & $29.1 \%$ & $13.8 \%$ & $45.9 \%$ & $50.0 \%$ & $30.0 \%$ & $27.3 \%$ & \\
\hline Not often - N & 95 & 25 & 20 & 3 & 7 & 16 & \\
\hline$\%$ & $70.9 \%$ & $86.2 \%$ & $54.1 \%$ & $50.0 \%$ & $70.0 \%$ & $72.7 \%$ & \\
\hline \multicolumn{3}{|c|}{ Family disinterest or resistance } & & & & & 6.57 \\
\hline \multirow[t]{2}{*}{ Often - } & 59 & 9 & 21 & 3 & 5 & 7 & \\
\hline & $43.7 \%$ & $31.0 \%$ & $58.3 \%$ & $50.0 \%$ & $50.0 \%$ & $31.8 \%$ & \\
\hline Not often - N & 76 & 20 & 15 & 3 & 5 & 15 & \\
\hline \multirow{2}{*}{ Other } & $56.3 \%$ & $69.0 \%$ & $41.7 \%$ & $50.0 \%$ & $50.0 \%$ & $68.2 \%$ & \\
\hline & & & & & & & 2.78 \\
\hline \multirow[t]{2}{*}{ Often - } & 8 & 1 & 1 & 1 & 0 & 2 & \\
\hline & $30.8 \%$ & $12.5 \%$ & $16.7 \%$ & $50.0 \%$ & $0.0 \%$ & $33.3 \%$ & \\
\hline \multirow{2}{*}{$\begin{array}{r}\text { Not often }-\mathrm{N} \\
\%\end{array}$} & 18 & 7 & 5 & 1 & 1 & 4 & \\
\hline & $69.2 \%$ & $87.5 \%$ & $83.3 \%$ & $50.0 \%$ & $100.0 \%$ & $66.7 \%$ & \\
\hline
\end{tabular}


$* p<.05 ; * * p<.01 ; * * * p<$ 
Results indicated that itinerant teachers of $\mathrm{d} / \mathrm{hh}$ students reported having no wifi as a challenge more frequently than other challenges. Itinerants also more frequently reported a lack of funding or inadequate funding for technology whereas those inschools for the deaf less frequently reported this as a challenge.

Next, the researcher examined the relationship between frequency of challenges faced and the geographic location in which the teacher works (see Table 17).

Table 17.

Chi-square analysis of relationship between frequency of challenges faced and environment in which teacher works.

\begin{tabular}{|c|c|c|c|c|}
\hline \multirow{2}{*}{\multicolumn{4}{|c|}{$\begin{array}{l}\text { Challenges } \quad \text { Urban } \\
\text { Hardware absent or outdated }\end{array}$}} & $X^{2}(d f)$ \\
\hline & & & & $1.90(2)$ \\
\hline \multirow[t]{2}{*}{ Often - } & 67 & 60 & 29 & \\
\hline & $69.8 \%$ & $60.6 \%$ & $67.4 \%$ & \\
\hline Not often - N & 29 & 39 & 14 & \\
\hline$\%$ & $30.2 \%$ & $39.4 \%$ & $32.6 \%$ & \\
\hline \multicolumn{4}{|c|}{ Software absent or outdated } & $.55(2)$ \\
\hline \multirow[t]{2}{*}{ Often - } & 69 & 65 & 29 & \\
\hline & $71.1 \%$ & $66.3 \%$ & $67.4 \%$ & \\
\hline Not often - N & 28 & 33 & 14 & \\
\hline$\%$ & $28.9 \%$ & $33.7 \%$ & $32.6 \%$ & \\
\hline \multicolumn{4}{|c|}{ No internet access } & $.98(2)$ \\
\hline \multirow[t]{2}{*}{ Often - } & 31 & 33 & 17 & \\
\hline & $32.0 \%$ & $33.3 \%$ & $40.5 \%$ & \\
\hline Not often - N & 66 & 66 & 25 & \\
\hline$\%$ & $68.0 \%$ & $66.7 \%$ & $59.5 \%$ & \\
\hline \multicolumn{3}{|c|}{ No Wifi access } & & $3.70(2)$ \\
\hline \multirow[t]{2}{*}{ Often - } & 33 & 38 & 22 & \\
\hline & $34.0 \%$ & $38.4 \%$ & $51.2 \%$ & \\
\hline Not often - N & 64 & 61 & 21 & \\
\hline$\%$ & $66.0 \%$ & $61.6 \%$ & $48.8 \%$ & \\
\hline \multicolumn{3}{|c|}{ No or inadequate training } & & $1.62(2)$ \\
\hline \multirow[t]{2}{*}{ Often - } & 59 & 58 & 30 & \\
\hline & $60.8 \%$ & $58.6 \%$ & $69.8 \%$ & \\
\hline Not often - N & 38 & 41 & 13 & \\
\hline$\%$ & $39.2 \%$ & $41.4 \%$ & $30.2 \%$ & \\
\hline \multicolumn{3}{|c|}{ No or inadequate funding } & & $2.49(2)$ \\
\hline \multirow{3}{*}{ 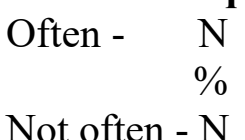 } & 66 & 61 & 32 & \\
\hline & $68.8 \%$ & $61.6 \%$ & $74.4 \%$ & \\
\hline & 30 & 38 & 11 & \\
\hline
\end{tabular}




\begin{tabular}{|c|c|c|c|c|}
\hline$\%$ & $31.3 \%$ & $38.4 \%$ & $25.6 \%$ & \\
\hline \multicolumn{4}{|c|}{ Fear of using new technology } & $1.79(2)$ \\
\hline \multirow[t]{2}{*}{ Often - } & 22 & 19 & 13 & \\
\hline & $22.9 \%$ & $19.4 \%$ & $29.5 \%$ & \\
\hline Not often - N & 74 & 79 & 31 & \\
\hline$\%$ & $77.1 \%$ & $80.6 \%$ & $70.5 \%$ & \\
\hline \multicolumn{4}{|c|}{ Lack of time for training or practice } & $1.54(2)$ \\
\hline \multirow[t]{2}{*}{ Often - } & 74 & 68 & 33 & \\
\hline & $77.1 \%$ & $69.4 \%$ & $75.0 \%$ & \\
\hline Not often - N & 22 & 30 & 11 & \\
\hline$\%$ & $22.9 \%$ & $30.6 \%$ & $25.0 \%$ & \\
\hline \multicolumn{3}{|c|}{ Student literacy level } & & $1.29(2)$ \\
\hline \multirow[t]{2}{*}{ Often - } & 79 & 76 & 32 & \\
\hline & $82.3 \%$ & $77.6 \%$ & $74.4 \%$ & \\
\hline Not often - N & 17 & 22 & 11 & \\
\hline$\%$ & $17.7 \%$ & $22.4 \%$ & $25.6 \%$ & \\
\hline \multicolumn{3}{|c|}{$\begin{array}{l}\text { Student disinterest or } \\
\text { resistance }\end{array}$} & & $2.96(2)$ \\
\hline \multirow[t]{2}{*}{ Often - } & 31 & 24 & 16 & \\
\hline & $32.3 \%$ & $24.5 \%$ & $38.1 \%$ & \\
\hline Not often - N & 65 & 74 & 26 & \\
\hline$\%$ & $67.7 \%$ & $75.5 \%$ & $61.9 \%$ & \\
\hline \multicolumn{3}{|c|}{$\begin{array}{l}\text { Family disinterest or } \\
\text { resistance }\end{array}$} & & $3.22(2)$ \\
\hline \multirow[t]{2}{*}{ Often - } & 41 & 38 & 23 & \\
\hline & $43.2 \%$ & $38.4 \%$ & $54.8 \%$ & \\
\hline Not often - N & 54 & 61 & 19 & \\
\hline$\%$ & $56.8 \%$ & $61.6 \%$ & $45.2 \%$ & \\
\hline \multicolumn{2}{|l|}{ Other } & & & $4.95(2)$ \\
\hline \multirow[t]{2}{*}{ Often - } & 9 & 3 & 1 & \\
\hline & $42.9 \%$ & $13.0 \%$ & $25.0 \%$ & \\
\hline Not often - N & 12 & 20 & 3 & \\
\hline$\%$ & $57.1 \%$ & $87.0 \%$ & $75.0 \%$ & \\
\hline
\end{tabular}

The results indicated that there were no significant relationships between frequency of challenges reported by teachers of $\mathrm{d} / \mathrm{hh}$ students and the geographic location in which the teacher works.

Finally, the researcher examined the relationship between frequency of challenges faced and the educational level of students taught (Table 18). Because of small expected cell counts, Fisher's exact test was used to test the relationships. 
Table 18.

Chi-square analysis of relationship between frequency of challenges faced and level of students taught.

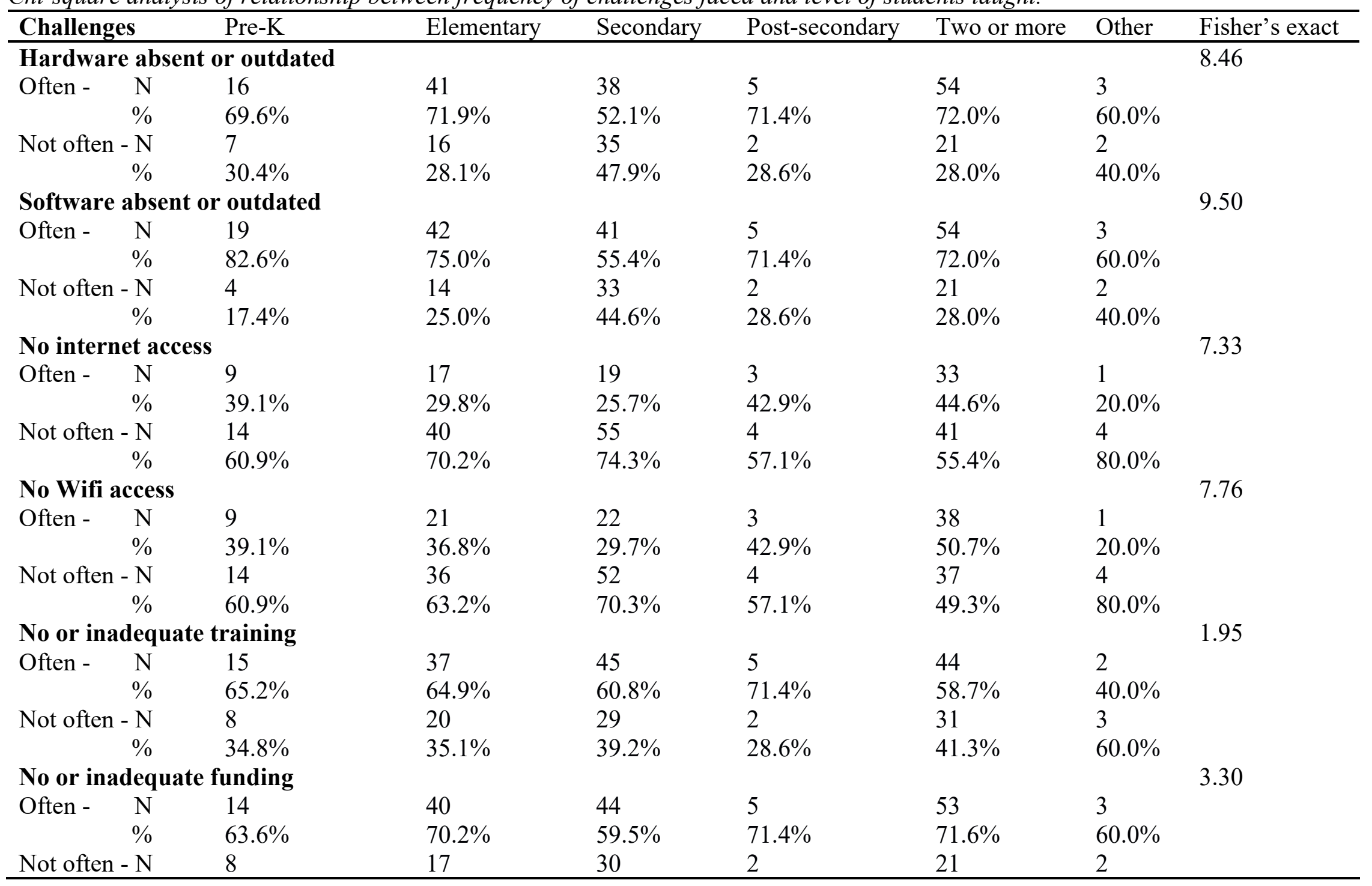




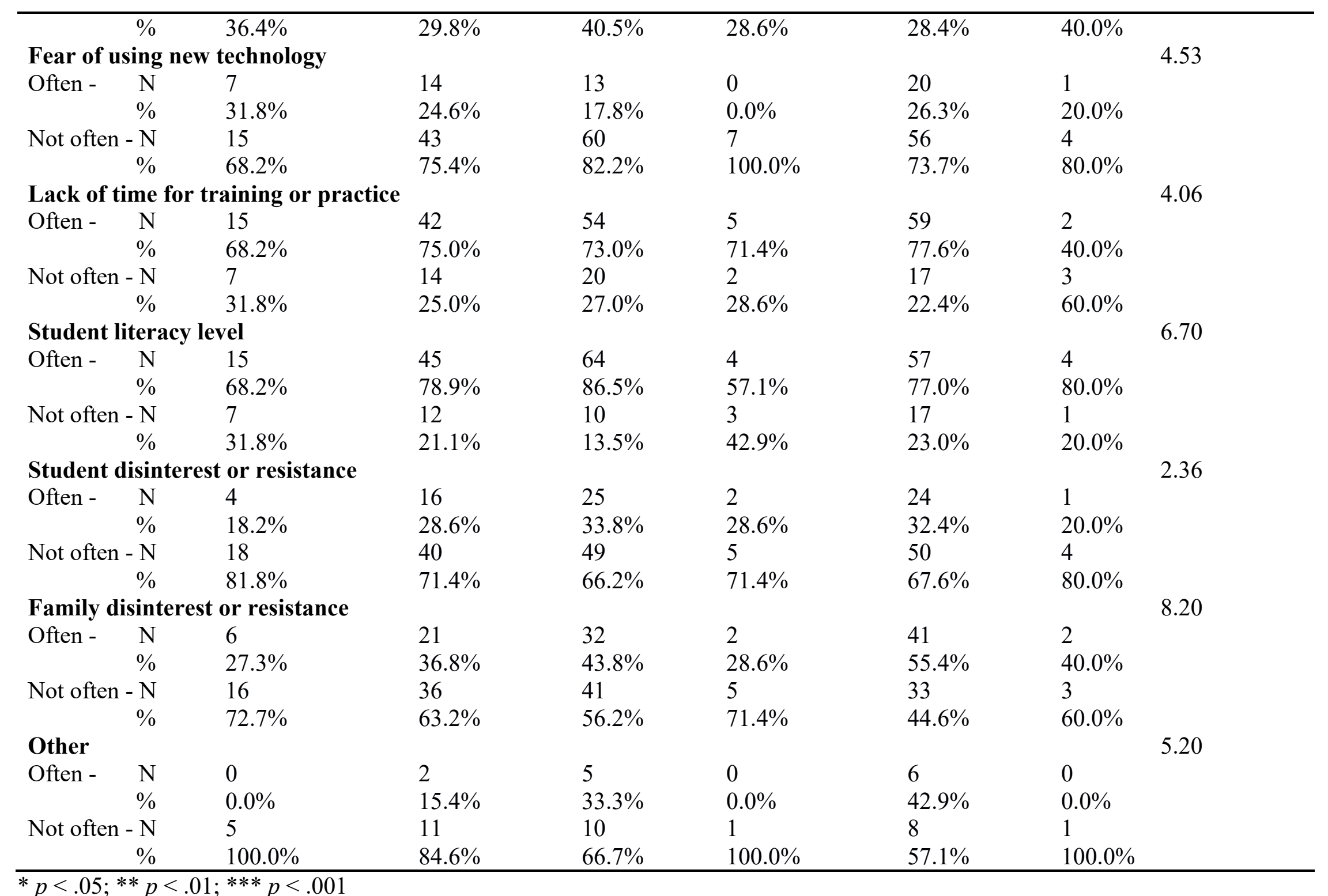


The results indicate that there were no significant relationships between frequency of challenges and the academic level of students taught. 


\section{Chapter Five: Discussion}

\section{Introduction}

In exploring the types and frequency of technology used by teachers of deaf and hard-of-hearing $(\mathrm{d} / \mathrm{hh})$ students nationwide, the findings of this study indicate that all of the participants of the study were using technology in their position as a teacher of deaf and hard-of-hearing $(\mathrm{d} / \mathrm{hh})$ students. This is significant in that it supports the proliferation of technology in among these specialized teachers within the greater field of education.

The use of technology for learning experiences as an agent for empowering the student and mitigating the educational inequities inherent in education is valued by administrators and program directors (Evans, 2017). This study provides additional insight into technology use as well as the various challenges and training/needs of the participants.

\section{Research Question 1}

The data collected suggests that the technology most often used for the design of content-based learning activities is the use of document writing software such as Microsoft Word, Google Docs, and Pages. As indicated by Maiorana-Basas and Pagliaro (2014), although the current literature does not specifically address the effects of technology applications on the literacy skills of $\mathrm{d} / \mathrm{hh}$ individuals, greater access to English language models may be provided through specific technologies. Word processing in particular has been cited as a possible means of promoting higher-order thinking. Those software applications may allow $\mathrm{d} / \mathrm{hh}$ students to focus on composing and communicating ideas first and later addressing the mechanics of writing. Word 
processing software allows students to review what they have written and make revisions easily. The tools in the program allow teachers and students to edit material easily; checking spelling and grammar, highlighting key ideas, sequencing sentences and paragraphs to flow more logically and better communicate the intent in English. Students may feel more motivated given the opportunity to publish more professional-looking documents. This technology also affords an opportunity to share their work, which can increase the student's awareness of the reader and encourage greater attention to the writing process and to constructing meaning for the audience (Means et al., 1993). More research, however, is needed.

Presentation software was also reported as a prevalent tool used to develop learning activities for students with hearing loss. The high use of word processing for instruction is consistent with prior research dating back to Roberson (2001) who documented that it is often some of the first technology available and modeled for teachers of $\mathrm{d} / \mathrm{hh}$ students in their preservice programs, in learning to use and integrate technology. Literature reveals that many teachers are comfortable in using basic technology applications (e.g. word processing, spreadsheets, databases) in the classroom but lacked effective skills and strategies to integrate some other instructional tools and productivity applications into their lessons (Keengwe \& Onchwari, 2009; Robertson, 2001).

Nearly $67 \%$ of participants responded that they used "Other" technology to design instructional activities and materials. Of the responses provided by these participants, the use of Google/Google Classroom tools $(5.70 \%, \mathrm{~N}=21)$ and SMART board/SMART 
Notebook $(5.40 \%, \mathrm{~N}=20)$, were the most common. One, is a learning management system (LMS) and the other a suite of educational software.

A high percentage of teachers of $\mathrm{d} / \mathrm{hh}$ students reported using search engines (e.g. Google, Yahoo, Bing) to deliver instruction. When designing academic content, participants reported using word processing applications more than any other technology included in the survey. Educational videos were the next most widely reported technology used for delivering academic content to students. Educational video services may be especially appealing as they allow for a multimedia experience that the viewer can largely control. Students can be interactive in sharing information, expressing opinions, and obtaining information or solutions based on the comments from the person who posted the video or from other viewers. This aligns with the current increasing use of educational video and other open source educational materials in education (Jones, 2018, Lim, Chew, Chan, Leow, Rozlan, \& Yong, 2017).

Over twelve percent of the participants provided the answer "Google" when asked if there was "Other" technology they used to provide instruction to students who are deaf or hard-of-hearing $(\mathrm{d} / \mathrm{hh})$. It is unclear as to why this answer was provided as an additional response when the third option for this survey question is "Search Engines (Google; Bing; Wikipedia)." It may be that the participants were referring to the various components of Google Classroom. In which case, the argument could be made that participants believed that reporting the use of this tool would satisfy the criteria of technology use across primary research questions of technology use for design, delivery, communication, and collaboration. This answer prevalence was noted, and future 
revisions of the survey tool should make efforts to clarify the specificity of the question as it pertains to the function of the use of a specific technology, or otherwise address this.

YouTube was listed as another means of delivering academic content to $\mathrm{d} / \mathrm{hh}$ students. This answer may have been written in by participants because, although "Educational Videos (Academic Earth, Learner.org, PBS, Khan Academy etc.)" was listed as a choice on the survey, YouTube was not specified as an example in this category. This may be remedied in any future survey questions by adding it to the list of examples.

\section{Research Question 1a}

In examining the relationship between technology use and job position, the researcher compared technology use against three discrete variables related to job position: setting, geographic location, and student's academic level. The results of the survey indicated that technology use varied somewhat depending the teacher's employment in a school for the deaf, resource room, itinerant, college, or in two or more of these settings. Each of these settings required different roles and responsibilities.

Those teachers employed in schools for the deaf indicated using presentation software for design of academic content more frequently than itinerant teachers. This is likely due to the fact that teachers employed in schools for the deaf provide more direct instruction in their role as a classroom teacher. Whereas itinerant teachers of $d / h h$ students provide a broader scope of service (e.g. teacher in-service, assistive technology, one on one support). As indicated in the literature, itinerant teachers are less likely to provide a great deal of direct instruction and spend more time in consultation and collaboration (Luckner \& Ayantoye, 2013; Luckner, 2011; Stinson \& Anita, 1999). This 
survey data suggests itinerant teachers are using phone/video phone and education apps for delivery of academic content more frequently than teachers in resource rooms or schools for the deaf.

Itinerant teachers reported using text messaging for content delivery. Although there are many new and interesting educational applications designed to encourage content delivery via mobile technology, the use of text messaging is a simple means of utilizing cell phone and tablets without necessarily needing access to broadband internet which is sometimes a challenge for itinerant teachers.

Although the use of text messaging for content delivery may be less viable with early literacy learners, there is a growing body of research to support the use of text messaging for enhanced literacy (Colwell, 2013; Thurlow \& Poff, 2013; Plester \& Wood, 2009; Wood \& Joshi, 2009; Plester \& Wood, 2008; Plester, Thurlow, \& Brown, 2003). Some of the ways in which teachers of $\mathrm{d} / \mathrm{hh}$ students might incorporate text messaging for instruction include: translating ASL to proper English, digital storytelling, retelling/reteaching a lesson to a family member or peer via text, use texting as means for notetaking, used to facilitate small group discussions, writing for different audiences, etc.

Itinerant teachers also reported using spreadsheet software more often for designing and delivering lessons, whereas those teachers of $\mathrm{d} / \mathrm{hh}$ students teaching in a resource room used this type of software less frequently than teachers of $d / h$ h students in other positions. There is ample information available online promoting the use of spreadsheet software for instruction specifically to make data sets visual and encourage active student participation across content areas. Interactive technology such as the interactive whiteboards help spreadsheets become interactive and encourages students to 
become active participants in their learning (Mackall, 2004). The survey data does not specify how these teachers were using the spreadsheet software to design and deliver content, so the researcher is unable to speculate why there would be greater use among itinerant teachers as opposed to those in other job positions.

The data from the survey indicated that those teachers of $\mathrm{d} / \mathrm{hh}$ students in urban settings were more likely to use presentation software for the design of lessons, whereas those in suburban settings were less likely. The opposite is true for the use of spreadsheet software in the design of academic content.

Effective lesson design with technology is dependent on technology access and teacher skills. As teachers have access to more training and advanced technology applications, there is a movement from the "adoption" and "adaptation" phases where primary technology applications are being adopted with traditional teaching methods such as lecture, to the "appropriation" and "invention" phases where the technology use is more advanced, and lessons are more project based and self-directed (Dwyer, Ringstaff, \& Sandholtz, 1991).

One of the potential challenges that can occur with technology is when access and use are not equitably distributed. The socioeconomic advantages of suburban school systems may enable those users to be among the first to have access to the latest digital and mobile technology whereas schools in urban or rural settings may lag behind in access and use of information and communication technology now prevalent in education (Cope \& Lee, 2016; Rawson, 2016; Rogers, 2016; Theobald, 2005).

Those teachers located in rural settings were more likely to use a phone or video phone for service delivery. Deaf and/or hard-of-hearing students in rural settings can 
sometimes be located at great geographic distances from one another. As indicated in the literature (Luckner \& Ayantoye, 2013), students who previously would travel to a central school for the deaf to receive specialized instruction are now being served in their home schools by an itinerant teacher of the deaf with much less frequency and intensity.

Communication technology such as video phone, live streaming, and conference software can now supplement in-person lessons helping meet the diverse needs of students and the ongoing teacher shortage (Hassel \& Dean, 2015).

Teachers of $d /$ hh students in suburban settings were more likely to use educational services for content delivery. Online educational services often require broadband internet and a subscription to access all of the resources available. This is typically provided by the school or district. Teachers located in suburban settings may have an advantage over those located in rural or urban centers where high speed internet and funds for such educational subscriptions might be less available.

The disparity in infrastructure, software, and training are all longstanding challenges for rural schools and programs as noted in the literature review (Harding \& Tidball, 1982; Israelite \& Hammermeister, 1986; Kluwin \& Nortetsky, 2005; Rose \& Waldon, 1984). Although there has been much written about "closing the digital divide," a recent article in the New York Times, states that there is still a large percentage $(10 \%$, $\mathrm{N}=34,0000$ ) of Americans do not have access to high speed internet in low income and rural areas (Kang, 2016).

Fortunately, there are ongoing initiatives such as Broadband Connects America Coalition, and Connect Americans Now which is focused on providing affordable universal service for all rural residents in America rather than allocate it based on profit 
and population density. These types of initiatives should help level the playing field and thereby increase digital literacy for students in those areas if teachers are given the access and training necessary to promote this skill set in their $\mathrm{d} / \mathrm{hh}$ students.

The use and frequency of technology for designing and delivering academic content varied some based on the level of students being taught. Teachers of $d / h h$ students in two or more settings reported being more likely to use learning management systems (LMS) such as Schoology, Google Classroom or Blackboard. Learning management systems (LMS) are organization and communication tools that allow students access to class announcements, assignments, grades, and collaborative tools all in one place.

These systems, especially Google Classroom, are becoming more available to school districts due to low cost and easy implementation. Teachers working with $\mathrm{d} / \mathrm{hh}$ students on varying academic levels and across multiple settings might be more likely use this technology because it is more secure than class webpages, it complies with Family Educational Rights and Privacy Act (FERPA), allows for data migration during school transitions and provides a blended learning environment. These things assist in differentiation as they allow the student some control over time, place, path, and/or pace of learning.

Learning management systems also allow itinerant teachers of $\mathrm{d} / \mathrm{hh}$ students to create or access existing virtual classrooms in their district. In this way, teachers of $d / h h$ students who are co-teachers and itinerant working with $\mathrm{d} / \mathrm{hh}$ students included in general education settings can add resources, add academic content for previewing, and make curricular modifications within those virtual classrooms. 
One drawback to these systems is that although LMS foster classroom community and capitalize on the accessibility of mobile technology, it may be restrictive to those students who are still learning basic literacy skills. Also, services such as these require students to be both effective creators of digital content and thoughtful consumers of digital content. Early learners are still becoming familiar with these technology skills which may be why teachers of elementary $\mathrm{d} / \mathrm{hh}$ students reported being less likely to use LMS.

Elementary school teachers of $\mathrm{d} / \mathrm{hh}$ students were also found to be less likely to use spreadsheet software for design. The reason elementary school teachers of $\mathrm{d} / \mathrm{hh}$ students may not use this particular software tool may be a lack of training and/or modeling for the specific task of planning and design. These teachers also were less likely to use texting for delivery of academic content. It follows that because language precedes literacy, teachers of $\mathrm{d} / \mathrm{hh}$ elementary students are less likely to use texting for content delivery. Students at this level may or may not have personal cell phones, but all are still learning to understand language and express language orally and/or through the air before they can learn print language. Texting is also not formal English and may confuse those who are still learning the basic conventions of the English language without the benefit of multiple exposure and modeling that incidental learning provides.

Those teachers employed in two or more academic levels were found to be more likely to use text for content delivery. This survey question did not specify which two (or more) academic levels the teachers taught who reported being more likely to use text for academic content delivery, so we are unable to speculate if this is based, in-part, on the reading level of the student. 
Secondary school teachers of $\mathrm{d} / \mathrm{hh}$ students reported they were less likely to use photo editing software for designing and delivering academic instruction, whereas those teachers of $\mathrm{d} / \mathrm{hh}$ students teaching in two or more academic levels reported being more likely to use photo editing software for lesson design. Digital cameras and video have been used for a greater part of the last decade to as educational tools used to create tutorials, visual art lessons as well as capture exemplars, document student skill levels and work samples (Sheperd \& Alpert, 2015). With the increased availability of personal technology such as smartphones and tablets, it is surprising that the survey data does not support a greater use of cameras and video use in designing and delivering instruction at the secondary level, however, it may be another testament to the lack of training opportunities and practice time to fully integrate this technology.

This survey found that teachers in preschool and elementary school settings were less likely to use e-mail and news/information websites for content delivery, while those teachers of $\mathrm{d} / \mathrm{hh}$ students in secondary settings were more likely. Like the prior discussion of using text messaging for academic delivery, it would follow the same logic that students must learn to read, before reading to learn. Thus, with those students in early education who have yet to master spoken or visual language, using e-mail or news/information websites (e.g. Time for Kids, NBC Learn) for academic content delivery would likely be ineffective as the majority these websites are not designed to meet the communication needs of early $\mathrm{d} / \mathrm{hh}$ learners.

The use of apps, academic services (e.g. iReady, KidBiz), and educational services (e.g. BrainPop, Cosmeo) for content delivery was reportedly used more often by elementary school teachers of $\mathrm{d} / \mathrm{hh}$ students. Many of the applications and services being 
adopted by districts allow for progress monitoring and differentiation of instruction. These services often choose the student's academic level based on an individual profile and baseline assessment of a student then adjust the lesson presentation and monitor progress. This purposeful use of technology to differentiate instruction can benefit $\mathrm{d} / \mathrm{hh}$ learners. Further research is needed to determine which of the technology being used by teachers of $\mathrm{d} / \mathrm{hh}$ students is proving most effective.

The use of multimedia applications for the instruction of learners with hearing loss is well supported and documented in the literature (Barker 2003, Cannon, Easterbrooks, Gagne \& Beal-Alverez, 2011; Gentry, Chinn, \& Molton, 2004/2005; Lang \& Steely, 2003; Mich, Pianta, \& Mana, 2013; Passig, \& Eden, 2010; Reitsma, 2009; Stoner, Easterbrooks, Laughton, 2005; Vesel, 2006; Vesel \& Robillard, 2013; Wang \& Paul, 2011). The curriculum presented with many educational services is media rich and provides common core aligned content in various formats. Designed with animations, videos and visuals to encourage learner engagement, the lessons provide material across topics to encourage academic literacy.

\section{Research question 1b}

Teachers' professional development is a key factor in successfully integrating technology into classroom instruction (Buabeng-Andoh, 2012). Recent literature restates what was found in the literature review. Technology integration is a process. A positive relationship was detected between a teacher's confidence and comfort using technology and the integration of technology into the classroom (Liu, Ritzhaupt, Dawson, \& Barron, 2017; Kluwin \& Nortetsky, 2005). 
When examining if there was a significant relationship between those teachers of $\mathrm{d} / \mathrm{hh}$ students who reported using technology for additional training and the use of technology for the design and delivery of academic content, there appears to be statistically significant relationships between those teachers who reported using technology for additional training and those who reported being more likely to use presentation software for developing academic content-based activities. Data from the survey also indicated a relationship between the teachers who reported using technology for additional training and the increased likelihood of their use of academic services and virtual assistants (e.g. Signing Avatars, Chatbots) for delivery of academic content.

\section{Research question 2}

The expectation for a $21^{\text {st }}$ century learner is to be able to effectively collaborate, think critically, problem solve, and synthesize various information while utilizing rapidly evolving digital technologies (Mishra, Koehler, \& Henriksen, 2011, Herold, 2016). Therefore, as teachers of $\mathrm{d} / \mathrm{hh}$ students integrating technology, it is important to explore the relationship between the use and frequency of various technologies to promote student communication and collaboration. Teachers of $\mathrm{d} / \mathrm{hh}$ students reported using closed or open captioning most often at $85 \%$ to promote communication. The use of an iPad or Tablet for communication was the technology reported second most frequently at nearly $80 \%$. Other technology that was reported as frequently used for communication included interactive whiteboards (77\%) and laptops (77\%).

The technology used most frequently for collaboration varied somewhat from that used for the purpose of promoting communication. Email was reported as the technology most likely to be used by teachers of $\mathrm{d} / \mathrm{hh}$ students for collaboration $(99 \%)$. Text 
messaging was the second most widely reported (87\%), followed by word processing $(83 \%)$, and phone/video phone (74\%). The high reported use of e-mail for collaboration is likely a product of school culture, with e-mail being readily available for all teachers and the vehicle for most school-wide communication. Lack of time to collaborate is often reported by teachers as a barrier to successful inclusive practices (Cook \& Friend, 2010). The proliferation of smart phones and tablets may account for the other significant technologies reportedly being used for collaboration. Mobile devices allow for text messages, word processing, and video communication to occur throughout the school day and from any location, allowing teachers to collaborate (e.g. teacher-to-colleague, student-to-teacher and student-to-content) more quickly and easily (O’Bannon \& Thomas, 2015; Cosier, Gomez, McKee, \& Maghzi, 2015).

\section{Research question 2a}

Technology used to promote communication and collaboration was examined in relationship to job position across three discrete variables: setting, geographic location, and student academic level. The results of the survey indicated that technology use for communication and collaboration varied somewhat depending on whether the teacher was employed in a school for the deaf, resource room, itinerant, college, or in two or more of these settings.

It was not surprising due the nature of their job position, often traveling between multiple schools and sometimes across long distances, that itinerant teachers reported being more likely than other teachers of $\mathrm{d} / \mathrm{hh}$ students to use a smart phone for communication. Itinerant teachers of $\mathrm{d} / \mathrm{hh}$ students have cited collaboration skills as essential to the success of their job (Luckner, 1991; Yarger \& Luckner, 1999; Foster and 
Cue, 2009). The Smartphone was a game changer in many ways. Itinerant teachers have reported on the improved connectivity, efficiency, and productivity with the use of mobile phones in the literature as early as 1994 (Corn \& Patterson, 1994). Smartphones now allow for access to calendar, e-mail, files, texting, mobile applications and a plethora of other tools beneficial for the traveling teacher. The survey indicated that although teachers in secondary settings were less likely to use iPads or captioning to promote communication, teachers in two or more settings were more likely to use both iPads and laptops for the purpose of communication.

Results of the Maiorana-Basas and Pagliaro (2014) survey identified that $\mathrm{d} / \mathrm{hh}$ young adults use smartphones, PCs, iPads, and iPods more frequently that older adults at home. The results indicated that a large majority of these young adults reported using technology for the purposes of e-mail, text messaging, and surfing the internet, social networking as well as for video editing, developing presentations, and creating spreadsheets. The high percentage of young adults using various technologies outside the classroom prompts the question of what technology knowledge and skills to $\mathrm{d} / \mathrm{hh}$ students bring with them to school and where do the gaps lie between these students and their hearing peers. Further studies need to be conducted to see how $\mathrm{d} / \mathrm{hh}$ students compare to their hearing peers in technology use and efficacy at varying ages and literacy levels to discover how teachers of $\mathrm{d} / \mathrm{hh}$ students can better differentiate instruction and support for this $\mathrm{d} / \mathrm{hh}$ students across learning environments.

Itinerant teachers and those located in rural settings reported being significantly more likely to use captioning/text interpretation to promote communication. Captioning displays the spoken dialogue of lectures and other educational media. Captions identify 
the speaker, describe any sound effects, music and laughter as it occurs. Captioning carries with it the potential benefit of aiding vocabulary development, improved reading comprehension, and content retention (Tamayo \& Chaume, 2017; Strassman \& O'Dell 2012; Stinson, Elliot, Kelly, \& Liu, 2009).

Data from those teachers of $\mathrm{d} / \mathrm{hh}$ students employed at schools for the deaf indicated they were less likely to use captioning/text interpretation to promote communication. This may be in part to the communication philosophy adopted at many schools for the deaf for deaf and hard-of-hearing students which prioritizes the child's first language, which in many cases is American Sign Language (ASL) or other manual language. Although not specified in the survey question, teachers in schools for the deaf may be more likely to use a video phone or phone to promote communication, this may be based on the preference for visual language use such as ASL. Smartphones with apps such as Facetime, Glide, or Tamaggo, allow for real time conversations in ASL over distance. Teachers in schools for the deaf did report being more likely to use phone/video phone for collaboration than those in other settings.

Teachers of $d /$ hh students in two or more settings reported being more likely to use deaf association websites for collaboration and those teaching across two or more academic levels were more likely to use social media for collaboration. Without the benefit of other teachers of the deaf, deaf associations and connections through social media may provide support through collaboration and the sharing of resources for those more isolated teachers of $\mathrm{d} / \mathrm{hh}$ students trying to meet the diverse and specialized needs of $\mathrm{d} / \mathrm{hh}$ students included in general education environments. 


\section{Research question $2 b$}

It is well documented that the successful implementation of education technologies depends upon high-quality professional development and ongoing support (Lemke \& Fadel, 2006; O’Dwyer, Russell, \& Bebell, 2004; Penuel, 2006). When examining if there was a significant relationship between those teachers of $\mathrm{d} / \mathrm{hh}$ students who reported using technology for additional training and the use of technology for communication and collaboration, a positive relationship emerged between those who used technology for training and those more likely to use an interactive whiteboard for communication and word processing for collaboration.

Although the data indicated a correlation between the use of technology for professional development, and teacher report of using specific types of technology for either designing and delivering academic content or promoting communication and collaboration, more information is needed to determine why those specific technologies were more likely used by teachers who also used technology for professional development. It may be that, in being introduced to and trained on a specific type of technology through their school or district, teachers may feel empowered to explore additional online training to extend their knowledge and use of this technology.

Preliminary data from this study may be used to inform further detailed questions on the type, duration, and relationship of the professional development to the technology use found to be significantly correlated to the training.

\section{Research Question 3}

Research question three examined the relationship between the self-reported use of technology by teachers of $\mathrm{d} / \mathrm{hh}$ students for additional training and their job position: 
setting, geographic location, and student's academic level. Teachers in schools for the deaf and those in two or more settings reported being less likely to use technology to obtain additional training in technology use and integration. Schools for the deaf are more likely to have a greater number of deaf education teachers to attract and justify the spending on disability specific training. Many schools for the deaf act as resource centers and are more likely to deliver training for professional development and support. There was no significant relationship found between technology use for additional training and the environment (urban, suburban, rural) in which the teacher of $d / h$ h students currently works. When examining the relationship between the use of technology and the academic level of students taught, the calculation of the Fisher's exact statistic failed to converge. Therefore, no statistical relationship emerged from this data set.

\section{Research Question 3a}

In taking a closer look at professional development, the next research question examined the relationship between employer-provided professional development and use of instructional technology. More frequent professional development in the use of technology was associated with more frequent use of presentation software for the designing of academic content and the use of learning management systems (LMS) for delivery of content. There were no positive associations found between professional development and technology used for communication, but there was a positive association found for employer-provided professional development and collaboration.

The technology used for collaboration with the greatest correlation to employer professional development was use of the school/class website. This is a very specific type 
of technology tool that is presumably used frequently by staff for collaboration which would promote a greater level of familiarity and comfort.

It is unclear why professional development was associated with the specific use of the aforementioned technology to design/deliver academic content or use for collaboration. Additional information as to the type of professional development, duration, format, and administrative support might provide additional data that would better guide administrators, program directors and teachers in the future.

\section{Research Question 4}

Technology has the potential to meet various educational needs. Teachers can address differentiation across instructional levels, meet differing communication needs, teach and model effective collaboration, while meeting the demands for progress monitoring and formative assessment (Hobsgood \& Ormsby, 2010) however there are persistent challenges that inhibit greater integration of technology among teachers of $d / h h$ students.

Beginning with one of the earliest studies in professional literature completed by Harding and Tidball (1982), major barriers to using technology with d/hh students: financial support, teacher training, lack of available hardware and/or software were firmly established and persisted the in literature. Of the challenges reported in this study, by teachers of $\mathrm{d} / \mathrm{hh}$ students with most frequency (79\%) was student literacy level.

Although it is clear from the Maiorana-Basas and Pagliaro (2014) survey of technology use by $\mathrm{d} / \mathrm{hh}$ adults, $\mathrm{d} / \mathrm{hh}$ individuals use technology in a variety of ways; it is unclear if $\mathrm{d} / \mathrm{hh}$ individuals have the skills needed to effectively use technology for the 
purpose of fact-based searches and independent learning. Additional inquiry is needed in this area.

Addressing the challenge of low literacy levels with $\mathrm{d} / \mathrm{hh}$ learners may be done so in a variety of ways. Begin integrating technology introducing related vocabulary early. Chose technology that uses graphical representations and search interfaces, as opposed to text for navigation and concept support (Smith, 2006). Introduce literacy applications or software that are leveled and track student progress while providing integrated supports for learners to promote success (e.g. KidBiz, Achieve 3000).

General educators need to make efforts to anticipate potential challenges of their learner in order to differentiate instruction. Teachers might consider using direct instruction to explicitly pre-teach or review the required reading comprehension strategies and related research skills to locate information and navigate the web or specific application of technology being used, prior to introducing a lesson. These skills might include rereading text, identifying context, locating pictures or related visuals, locating key words, context clues, and using embedded links. In this way, instructors can assess students' prior knowledge and build the vocabulary and skills required by the students to accomplish specific academic tasks using technology.

Next, teachers reported lack of time for training or practice $(74 \%)$, absent or outdated software (68\%), lack of or inadequate funding (67\%), and absent or outdated hardware $(65 \%)$ as barriers to integrating technology for instruction. While exploring the frequency of reported challenges as related to job position, itinerant teachers more frequently reported having no WiFi. A lack of funding, or inadequate funding for instructional technology was also a challenge often reported by itinerant teachers. This 
differed from those teachers employed at schools for the deaf who did not report funding issues in relation to technology use and integration. There were no significant relationships found between the frequency of challenges faced by teachers of $d / h h$ students and their geographic location or the academic level of the students taught.

Given that schools for the deaf may allocate more resources and funding to disability specific professional development based on capacity and the inherent interest in the unique needs of this population, it would behoove administrators and principles to foster stronger relationships with these schools, as well as preservice programs for teachers of the deaf in an effort to provide more cost-effective professional development and resources to their teachers of $\mathrm{d} / \mathrm{hh}$ students . In this way, administrators and principles will increase teacher access to disability specific resources and extend support to their itinerant personnel out in the field.

These stronger relationships can provide collaborative opportunities for teachers as well as inform schools for the deaf and preservice programs of the current challenges and needs of those partner teachers in the field. Additionally, online websites such as deafed.net, Success for Students with Hearing Loss, and Hands and Voices that provide resources, mentors, subscriptions, and PD opportunities can be made available to teachers of $\mathrm{d} / \mathrm{hh}$ students. Collaborative groups on social media (e.g. "Teachers for Deaf and HoH," "Itinerant Teachers for deaf HoH." and "The Radical Middle” on Facebook), could be also be utilized.

\section{Limitations}

Limitations that must be considered when reflecting on the results of this study are included here. The small sample size $(\mathrm{N}=369)$ and specific characteristics of the 
sample (more than half of the participants were employed at schools for the deaf) limit the degree to which the findings were able to be generalized.

First, although the study was distributed via a snowball sampling method whereas the initial contacts consisted of administrators for teachers in a variety of educational settings (e.g. inclusion, school for the deaf, resource room), as well as professional organizations for teachers of the deaf, who then forwarded the survey on to teachers of $\mathrm{d} /$ hh students and others like themselves (Coleman, 1958), more than half the respondents were employed in schools for the deaf. The bias was not likely a result of the design of the study or the collection procedure, but due to administrators and staff of the schools for the deaf, inherent interest and investment in the results of the survey due to specialized nature of the student population. Whereas the contrary may be true for the low response of those program directors and administrators of teachers of $\mathrm{d} / \mathrm{hh}$ students in itinerant and resource room positions. These individuals may not be as invested in the results of such a survey due to the low incidence of the $\mathrm{d} / \mathrm{hh}$ student population as viewed within the context of the broader special education population and therefore competing tasks may have taken priority over the dissemination of this survey.

Second, this survey method captured the participants experience at a single point in time. Due to the rapid change in technology and the ongoing integration of technology in educational institutions, the participants of this survey may have acquired additional training and/or may be using new technology now. It is not assumed that the frequency of technology use equals successful integration or desired outcomes by the participants. Data from this study may be used to inform future questions regarding the efficacy of technology chosen. 
The fact that a large number of the participants did not complete elements of the demographic questions is a methodological limitation. In the future, this may be remedied by moving the demographic questions to the beginning of the survey and making those questions forced-choice questions to secure this information before participants proceed.

In an effort to obtain a more definitive data set allowing for a more robust analysis, those questions with more than one possible answer should allow for participants to indicate two or more of the answer choices provided. This was not possible in the original survey. For example, a question in the survey allows participants to answer that they were employed in two or more academic levels but did not ask what those academic levels were.

These data can serve to inform administrators and program directors who face the ongoing challenge of keeping up with the rapidly evolving technology advancements and guiding the impact technology has on their teachers and students. The purpose of this research was to explore the types and frequency of technology used by teachers of $\mathrm{d} / \mathrm{hh}$ students to design and deliver academic content, as well as promote communication and collaboration with their students. Further study including a broader range of participants in job positions other than school for the deaf would yield a more inclusive data set and allow for greater generalization.

\section{Implications}

Challenges in the use of technology for education are long-standing and require continued initiatives to provide improved access, infrastructure, training, and support. On its own, access, connectivity and devices do not guarantee engaging educational 
experiences (Harding \& Tidball, 1982; Israelite \& Hammermeister, 1986; Kluwin \& Nortetsky, 2005; Rose \& Waldon, 1984).

The greatest barrier expressed by participants was the literacy level of their students. The literacy level of deaf and hard-of-hearing students has been addressed in terms of academic progress, achievements, transition to post-secondary. Given the centrality of this issue to learning, and insufficient research on $\mathrm{d} / \mathrm{hh}$ student efficacy in technology use for learning, I would assert that further exploration of how English literacy and related access issues impact the teacher's ability to integrate technology and teach $21^{\text {st }}$ century skills required for the success of $\mathrm{d} / \mathrm{hh}$ learners.

Given the outcomes of the Maiorana-Basas and Pagliaro (2014) survey of technology use by $\mathrm{d} / \mathrm{hh}$ adults, additional inquiry into the use and efficacy of technology use by $\mathrm{d} / \mathrm{hh}$ students outside the classroom is needed to determine how teachers might leverage the knowledge and skills these students bring to the classroom.

Regardless of the setting, geographic location, or level of students, educators of d/hh students use technology. The technology used varies some in accordance with the variables of the job position and specific challenges. However, several challenges remain the same as those cited in prior surveys. Teachers of $d / h h$ students continue to need more time for training and practice, updated hardware and software, as well as funding for technology.

\section{Conclusion}

Differentiation occurs as teachers become increasingly proficient in understanding their students as individuals, increasingly comfortable with the meaning and structure of the disciplines they teach, and increasingly competent at teaching flexibly in order to 
match instruction to student need with the goal of maximizing the potential of each learner in a given area (Tomlinson, 2003).

The findings of this study expand the on existing literature by providing additional information in the area of technology use by teachers of $d /$ hh students. The new knowledge from this study extends and builds upon the existing literature, focusing on teachers of deaf or hard-of-hearing students, and adding to the limited research in the area of teacher technology-based instructional practices and engagement.

Teachers of students who are $\mathrm{d} / \mathrm{hh}$ require a highly specialized skills set. They are required to know basic pedagogy, content of all major academic areas for students age 321, skills and knowledge of the expanded core curriculum, and specialized communication skills. They are expected to have knowledge of Deaf culture, assistive technology, and special education law. Additionally, they must model higher-order thinking, work in interdisciplinary teams, while demonstrating leadership and collaboration skills often as the only member of the educational team with this level of specialized knowledge.

In this role, the use of technology can be transformative. It can increase differentiation, decrease isolation, provided specialized resources and increase productivity for teachers and students. Educational technology can empower students to develop their knowledge and skills actively and experientially in a variety of learning environments. It allows for individual and collaborative growth while embedding assessment and providing immediate feedback. However, much is still unknown about the ways in which teachers of $\mathrm{d} / \mathrm{hh}$ students choose the technology they use for the 
purpose of designing and delivering academic content, promoting communication and collaboration among $\mathrm{d} / \mathrm{hh}$ students and their peers and the educational team.

This study provides a foundation of data regarding the kinds and frequency of technology being used by teachers of $\mathrm{d} / \mathrm{hh}$ students across job positions, geographic location, and academic level. It confirms the growing use of technology in the field of deaf education and provided data in the distinct differences pertaining to the types of technology used by teachers in specific instructional roles with students who have hearing loss and the persistent challenges yet to be successfully addressed.

\section{Recommendations for Future Study}

In looking forward, it would be beneficial to explore in greater detail the effectiveness of those chosen technologies by teacher job position (e.g. schools for the deaf, resource room, itinerant, and college/university). There is much to be learned about the ways in which technology can be used to ensure equal access to the core and specialized curricula including those non-cognitive competencies (e.g. self-concept, selfmanagement, social awareness, and interpersonal skills as well as motivation, and perseverance), and to enable $\mathrm{d} / \mathrm{hh}$ students to effectively compete with hearing peers in school and in society. It is important to know how teachers of $\mathrm{d} / \mathrm{hh}$ students choose the technology they use.

In learning to do so, they navigate the complex interplay of content, pedagogy, and technology knowledge, as well as how effective each type of technology is for the purpose it was chosen. This study will better guide administrators, principles, and program directors how teachers of $\mathrm{d} / \mathrm{hh}$ students integrate technology and the current needs in this area. Training and professional development in this area is critical and can 
be improved upon with more targeted support. Although the use of technology for the purpose of instructing students in $\mathrm{K}-12$ classrooms in the United States has been growing rapidly, national data available addressing the quality and effectiveness of these technologies are limited and research has thus far only shown limited positive effects on learning overall (Snyder and Dillow, 2013; U.S. Department of Education, 2016a).

Traditional teacher training does not address all of the needs and expectations of those teachers in specialized roles such as teachers of deaf students or visually impaired. Technology can help teachers to meet some of these expectations by providing tools to increase student engagement, learning, and communication, improve personal access to information and resources, as well as increase access to colleagues and collaboration opportunities. As teachers experience the potential of new technology to help them respond to these expectations, their demand for training in the use of instructional technology will grow.

Further investigation into the knowledge, skills, and preferences of $\mathrm{d} / \mathrm{hh}$ students' technology use both in and outside of the classroom will also better inform teachers, principals, administrators and program directors in the use of technology to design and deliver instruction for $\mathrm{d} / \mathrm{hh}$ students (Mercado, 2013). Prior research (Okuyama \& Iwai, 2011; Smith, 2006) indicates that late language acquisition, lower literacy skills, and lack of critical thinking may impact effective student use of technology. As such, it is important to address the knowledge, skills and preferences of $\mathrm{d} / \mathrm{hh}$ students' use of technology in an effort to provide the support and scaffolding needed to be effective technology users. 
The data from this study may also serve to help inform future researchers and technology developers. Thoughtful intervention and attention to the way technology is designed is also required for successful integration and to allow teachers multiple means of representing information to the student, quick assessment and production of student data and patterns that help teachers. Digital tools and online environments may augment the capacity of these teachers to effectively deliver content, communicate, and prepare students with hearing loss for successful post-secondary living.

By examining the relationship between technology use and various job position variables it is hoped that future training can be developed to improve the core technology competencies and skills needed by instructors of $\mathrm{d} / \mathrm{hh}$ students. In examining the technology use and challenges by teachers of $\mathrm{d} / \mathrm{hh}$ students, future professional development can be presented in a way that effectively provides ongoing training, models, and practice to effectively integrate and use digital content as needed across learning environments to assist $\mathrm{d} / \mathrm{hh}$ students in developing the skills needed to be successful in the future. 


\section{References}

Adamo-Villani, N. (2007). A virtual Learning environment for deaf children: Design and evaluation. International Journal of Human and Social Sciences, 2(2), 123-128.

Adamo-Villani N., \& Anasingaraju S. (2017). Holographic signing avatars for deaf education. In G. Vincenti, A. Bucciero, M. Helfert, \& M. Glowatz (Eds.), ELearning, E-Education, and Online Training. Third International Conference, eLEOT 2016, Dublin, Ireland, August 31 - September 2, 2016, Revised Selected Papers (pp. 54-61). New York, NY: Springer.

Adamo-Villani, N., Carpenter, E., \& Arns, L. (2006, June). 3D sign language mathematics in immersive environment. Proceedings of the 15th IASTED International Conference Applied Simulation and Modeling, Rhodes, Greece.

Adamo-Villani, N., \& Wright, K. (2007). SMILE: an immersive learning game for deaf and hearing children. ACM Proceedings of SIGGRAPH 2007- Educators, 5-10 August 2007, San Diego, ACM Digital Library. New York: ACM Publications.

Anderson-Inman, L., \& Horney, M.A. (1998). Transforming text for at risk readers. In Anderson-Inman, L. \& Horney, M.A. (2007). Supported e-Text: Assistive technology through text transformations. Reading Research Quarterly, 42(1), 153-160.

Anderson-Inman, L., Terrazas-Arellanes, F. E., \& Slabin, U. (2009). Supported eText in captioned videos: A comparison of expanded versus standard captions on student compre- hension of educational content. Journal of Special Education Technology, 24(3), 21-34. Retrieved from http://www. editlib.org/p/105161 
Barker, L. J. (2003). Computer-assisted vocabulary acquisition: The CSLU vocabulary tutor in oral-deaf education. Journal of Deaf Studies and Deaf Education, 8(2), 187-198.

Beal-Alvarez, J., \& Cannon, J. E. (2014). Technology intervention research with deaf and hard-of-hearing learners: Levels of evidence. American Annals of the Deaf, $158(5), 486-505$.

Beamish, W. (2008). Consensus about program quality: An Australian study in early childhood special education. Saarbrucken, Germany: VDM.

Berger, K. W. (1988). History and development of hearing aids. Amplification for the Hearing-impaired. New York: Grune and Stratton, Inc.

BrainPop. (2019). BrainPop. [Mobile application software]. Retrieved from https://www.brainpop.com

Brown, A., \& Green, T. (2012). QR codes in the classroom: Applications of augmented reality. In P. Resta (Ed.), Proceedings of Society for Information Technology \& Teacher Education International Conference 2012 (pp. 3434-3436). Chesapeake, VA: AACE.

Cambra, C, Silvestre, N., \& Leal, A. (2008/2009). Comprehension of television messages by deaf students at various stages of education. American Annals of the Deaf 153(5), 425-434. doi:10.1353/aad.0.0065

Cannon, J. E., Easterbrooks, S. R, Gagné, E, \& Beal-Alvarez, J. (2011). Improving D/HH students' grammar through an individualized software program. Journal of Deaf Studies and Deaf Education, 16(4), 437-457. doi:10.1093/deafed/enr023 
Cannon, J. E., Fredrick, L. D., \& Easterbrooks, S. R. (2010). Vocabulary instruction through books read in American Sign Language for English-language learners with hearing loss. Communication Disorders Quarterly, 37(2), 98-112.

Cannon, J. E., Guardinao, C., Antia, S. D., \& Luckner, J. L. (2016). Single-case design research: Building the evidence-base in the field of education of deaf and hard-ofhearing students. American Annals of the Deaf, 160(5), 440-452.

Chen-Chung Liu, Chien-Chia Chou, Baw-Jhlune Liu, \& Jui-Wen Yang. (2006). Improving Mathematics Teaching and Learning Experiences for Hard of Hearing Students with Wireless Technology-Enhanced Classrooms. American Annals of the Deaf, 151(3), 345-355. https://doiorg.www.libproxy.wvu.edu/10.1353/aad.2006.0035

Clemens, R., Purcell, S., \& Slykhuis, D. (2013). Augmented Education: How can augmented reality be incorporated into pre-service teacher education to help K-12 students?. In R. McBride \& M. Searson (Eds.), Proceedings of Society for Information Technology \& Teacher Education International Conference (pp. 1499- 1502). New Orleans, Louisiana, United States: Association for the Advancement of Computing in Education (AACE).

Clymer, E. W., \& McKee, B. G. (1997). The promise of the World Wide Web and other telecommunication technologies within deaf education. American Annals of the Deaf, 142(2), 104-106.

Cohen, J., Cohen, P., West, S. G., \& Aiken, L. S. (2015). Applied multiple regression/correlation analysis for the behavioral sciences. New York: Routledge. 
Colwell, J. (2013). Library Media Connection, 32(1), 14-16.

Compton, M. V., Appenzeller, M., Kemmery, M., \& Gardiner-Walsh, S. (2015). Itinerant Teachers' Perspectives of Using Collaborative Practices in Serving Students Who Are Deaf or Hard-of-hearing. American Annals of the Deaf, 160(3), 254-272. https://doi-org.www.libproxy.wvu.edu/10.1353/aad.2015.0023

Converse, J. M., \& Presser, S. (1986). Survey Questions: Handcrafting the Standardized Questionnaire Sage University Papers Series. Quantitative Applications in the Social Sciences (07-063). Retrieved from https://shop.phdkar.ir/wpcontent/uploads/2017/09/Survey-Questions-Handcrafting-the-StandardizedQuestionnaire-Quantitative-Applications-in-the-Social-Sciences.pdf

Cope, M., \& Lee, B. H. Y. (2016). Mobility, Communication, and Place: Navigating the Landscapes of Suburban U.S. Teens. Annals of the American Association of Geographers, 106(2), 311-320. https://doiorg.www.libproxy.wvu.edu/10.1080/24694452.2015.1124017

Corbett Jr, E. E., \& Micheaux, P. A. (1996). How some schools for deaf and hard-ofhearing children are meeting the challenges of instructional technology. American Annals of the Deaf, 141(2), 51-58.

Corn, A. L., \& Patterson, W. (1994). The use of mobile phones by itinerant teachers of students with visual disabilities. Journal of Visual Impairment \& Blindness, 88(5), 446. Retrieved from http://www.libproxy.wvu.edu/login?url=http://search.ebscohost.com/login.aspx?d $\underline{\text { irect }=\text { true } \& d b=a 9 h \& A N=9502173111}$ 
Cosier, M., Gomez, A., McKee, A, \& Maghzi, K.S. (2015). Smart-phones permitted: How teachers use text messaging to collaborate. Education and Information Technologies, 20(2), 347-358.

Creswell, J. W. (2009). Research design: Qualitative, quantitative, and mixed methods approaches (3rd ed.). Thousand Oaks, CA: Sage Publications.

Culp, K. M., Honey, M., \& Mandinach, E. (2003). A retrospective on twenty years of education technology policy. Washington, DC: U.S. Department of Education, Office of Educational Technology. Retrieved February 20, 2015, from https://www2.ed.gov/rschstat/eval/tech/20years.pdf

Curl, J. C., \& Mann, P. S. (2001). Introductory statistics: Student study guide. New York: Wiley.

Deninger, M. L. (1985). Plenary Address: Is It Still an Apple for the Teacher? American Annals of the Deaf, 130(5), 332-339.

Discovery Communications. (2006). Cosmeo. [Mobile application software]. Retrieved from https://cosmeo.com/welcome/index.html

Donne, V. (2013). Technology to Support Sign Language for Students with Disabilities. Rural Special Education Quarterly, 32(4), 24-37.

Druin, A., \& Hendler, J. (Eds.) (2000). Robots for Kids: Exploring new technologies for learning. San Francisco: Morgan Kaufmann.

Easterbrooks, S., Stephenson, B., \& Mertens, D. (2006). Master teacher responses to twenty literacy and science/math practices in deaf education. American Annals of the Deaf, 151(4), 398-409. 
Evans, J. (2017). BEYOND ENGAGEMENT: Using technology to enable learning experiences and empower educational effectiveness. Knowledge Quest, 39(2), 2027. Retrieved from https://tomorrow.org/speakup/pdfs/speakup2017-educationalequity-imperativeseptember2018.pdf?utm_source=ProjectTomorrow\&utm_medium=Web\&utm ca mpaign $=2018$ K 12 _CE_Suite_EffectiveCommunication\&utm_term=ReportDigitalTrends\&utm_content $=2018 \_$K12_PL_Suite_DigitalTrends-

\section{$\underline{\text { ProjectTomorrow }}$}

Fahy, P. J. (1985). Instructor attitudes affecting adoption of instructional innovations. Association for Educational Data Systems Journal, 19(1), 66-79.

Firmin, M. W., \& Genesi, D. J. (2013). History and implementation of classroom technology. Procedia-Social and Behavioral Sciences, 93, 1603-1617.

Foster, S., \& Cue, K. (2009). Roles and responsibilities of itinerant specialist teachers of deaf and hard-of-hearing students. American Annals of the Deaf, 153, 435-449.

Frampton, L. M. (2014). Youth and technology: An Adlerian-based analysis of smartphones and the impact of social media on females ages 12-17 (Unpublished Master's thesis). Adler Graduate School, Richfield, Minnesota.

Gardner, D. P. (1983). A nation at risk: The imperative for educational reform. An open letter to the American people. A report to the nation and the Secretary of Education. Washington D. C.: Department of Education. National commission on Excellence in Education. 
Gentry, M. M., Chinn, K. M., \& Moulton, R. D. (2004/2005). Effectiveness of multimedia reading materials when used with children who are deaf. American Annals of the Deaf 149(5), 394-403.

Goldin-Meadow, S. (1999). What children contribute to language learning. Science Progress. 82(1), 89-102.

Goldin-Meadow, S., \& Mylander, C. (1990). The role of parental input in the development of a morphological system. Journal of Child Language, 17(3), 527-563.

Hamilton, H. (2012). The efficacy of dictionary use while reading for learning new words. American Annals of the Deaf 157(4), 358-372.

Harding, R. E., \& Tidball, L. K. (1982). A national microcomputer-software survey of current microcomputer usage in schools for the hearing impaired. American Annals of the Deaf, 127(5), 673-683.

Harkins, J. E. (1994). Telecommunications for Deaf and Hard-of-Hearing Children: Educating the Schools. Technology and Disability, 3(3), 195-198.

Harkins, J. E., Loeterman, M., Lam, K., \& Korres, E. (1996). Instructional technology in schools educating deaf and hard-of-hearing children: A national survey. American Annals of the Deaf, 141(2), 59-65.

Hart, B., \& Risley, T. R. (2003). The early catastrophe. The 30 million word gap. American Educator, 27(1), 4-9.

Hassel, B. C., \& Dean, S. (2015). Technology and rural education. Boise, ID: Rural Opportunities Consortium of Idaho. 
Herold, B. (2016, February 05). Technology in Education: An Overview. Retrieved April 17, 2017, from http://www.edweek.org/ew/issues/technology-ineducation/index.html

Hobgood, B., \& Ormsby, L. (2010). Inclusion in the 21st-century classroom: Differentiating with technology. Learn NC: UNC, Chapel Hill.

Holmes, A. E., Kaplan, H. S., \& Saxon, J. P. (2000). Assistive listening devices and systems: Amplification technology for consumers with hearing loss. Journal of Rehabilitation, 66(3), 56.

Individuals with Disabilities Education Improvement Act of 2004, 20 U. S. C. $33 \S 1400$ et seq. (2004).

Institute of Education Sciences. (2011). WWC procedures and standards handbook version 2.0. Retrieved from http://ies.ed.gov/ncee/wwc/DocumentSum.aspx?sid=19

Institute of Education Sciences. (2013). WWC procedures and standards handbook version 3.0. Retrieved from http://ies.ed.gov/ncee/wwc/pdf/reference_resources/wwc_procedures_v3_0_draft _standards_handbook.pdf

Israelite, N, K., \& Hammermeister, F. K. (1986). A survey of teacher preparation programs in education of the hearing impaired, American Annals of the Deaf. 131(3), 232-237.

Itinerant Teachers of Deaf. (n.d.) Timeline [Facebook page]. Retrieved from https://www.facebook.com/groups/163744303979326/

Jaballah, K., \& Jemni, M. (2013). A Review on 3D Signing Avatars: Benefits, Uses and 
Challenges. International Journal of Multimedia Data Engineering and Management (IJMDEM), 4(1), 21-45. doi:10.4018/jmdem.2013010102

Jackson, A., Gaudet, L., McDaniel, L., \& Brammer, D. (2009). Curriculum integration: The use of technology to support learning. Journal of College Teaching and Learning, $6(7), 71-78$

Jaeger, P. T., Thompson, K. M., \& Lazar, J. (2012). The Internet and the evolution of library research: The perspective of one longitudinal study. The Library, 82(1).

Jeffs, T., Morrison, W. F., Messenheimer, T., Rizza, M. G., \& Banister, S. (2003). A retrospective analysis of technological advancements in special education. Computers in the Schools, 20(1-2), 129-152.

Jobs for the Future \& the Council of Chief State School Officers. 2015. Educator Competencies for Personalized, Learner-Centered Teaching. Boston, MA: Jobs for the Future.

Jones, S. (2018, October 03). Q\&A with an Ed-Tech Expert: Don't Focus on the Tools. Retrieved November 22, 2018, from https://www.edweek.org/ew/index.html Jones, T. W. (1984). A framework for identification, classification and placement of multi-handicapped hearing impaired students. Volta Review, 86(2), 142-151.

Kang, C. (2016, June 07). The Challenges of Closing the Digital Divide. Retrieved October 10, 2018, from https://www.nytimes.com/2016/06/09/technology/thechallenges-of-closing-the-digital-divide.html

Kannapell, B. (1989). Inside the deaf community. In S. Wilcox (Ed.), American deaf culture: An anthology (pp. 21-28). Silver Spring, MD: Linstock Press. 
Kaye, H. S. (2000). Computer and Internet Use among People with Disabilities. Disability Statistics Report 13.

Keengwe, J., \& Onchwari, G. (2009). Technology and early childhood education: A technology integration professional development model for practicing teachers. Early Childhood Education Journal 37, 209-218.

Kluwin, T. N., \& Noretsky, M. (2005). A mixed-methods study of teachers of the deaf learning to integrate computers into their teaching. American Annals of the Deaf, $150(4), 350-357$.

Kuk, F. (1992). Amplification devices for the hearing impaired individuals. Otolaryngology-Head and neck Surgery, 4, 3127-3141.

Lang, H., \& Steely, D. (2003). Web-based science instruction for deaf students: What research says to the teacher. Instructional Science, 31, 277-298.

Latif, F. (2012). CARE: Creating augmented reality in education. In T. Amiel \& B. Wilson (Eds.), Proceedings of World Conference on Educational Multimedia, Hypermedia and Telecommunications 2012 (pp. 666-669). Chesapeake, VA: Association for the Advancement of Computing in Education (AACE).

Lemke, C., \& Fadel, C. (2006). Technology in schools: What the research says. Culver City, CA: Metiri Group for Cisco Systems.

Lewis, M. S. J., \& Jackson, D. W (2001). Television literacy: Comprehension of program content using closed captions for the deaf. Journal of Deaf Studies and Deaf Education, 6(1), 43-53.

Lim, W. Y., Chew, Y. X., Chan, C. Y., Leow, S. K., Rozlan, S. B., \& Yong, W. J. (2017). Students' Acceptance of YouTube for Procedural Learning. In N. Suki 
(Ed.), Handbook of Research on Leveraging Consumer Psychology for Effective Customer Engagement (pp. 57-74). Hershey, PA: IGI Global. doi:10.4018/978-15225-0746-8.ch004

Liu, F., Ritzhaupt, A., Dawson, K., \& Barron, A. (2017). Explaining technology integration in K-12 classrooms: a multilevel path analysis model. Educational Technology Research \& Development, 65(4), 795-813. https://doiorg.www.libproxy.wvu.edu/10.1007/s 11423-016-9487-9

Lloyd, B. H., \& Gressard, C. (1984). Reliability and factorial validity of computer attitude scales. Educational and Psychological Measurement, 42, 501-5.

Lockard, C. B., \& Wolf, M. (2012). Occupational employment projections to 2020. Monthly Labor Review,135(1), 84-108.

Loeterman, M., Paul, P.V., \& Donahue, S. (2002, February). Reading and deaf children. Reading Online, 5(6).

Luckner, J. (1991). Consultation skills for teachers of students with hearing impairments. Volta Review, 93, 311-322.

Luckner, J. (2011). Promoting resilience: Suggestions for families, professionals, and students. In D. H. Rand \& K. J. Pierce (Eds.), Resilience in deaf children (pp. 207-226). New York, NY: Springer.

Luckner, J., \& Ayantoye, C. (2013). Itinerant teachers of students who are deaf or hard-ofhearing: Practices and preparation. Journal of Deaf Studies and Deaf Education, 18, 409-423. doi:10.1093/deafed/ent015

Luckner, J. L., Muir, S. G., Howell, J. J., Sebald, A. M., \& Young, I. J. (2005). An Examination of the Research and Training Needs in the Field of Deaf 
Education. American Annals of the Deaf, 150(4), 358-368. https://doiorg.www.libproxy.wvu.edu/10.1353/aad.2005.0042

Mackall, P. (2004). Interactive whiteboards enhancing the learning experience for deaf, hard-of-hearing students. TH E Journal, 31(10), 64-66.

Maiorana-Basas, M., \& Pagliaro, C. (2013). Technology use among adults who are deaf and hard-of-hearing: A national survey. Journal of Deaf Studies and Deaf Education, 19(3):400-10. doi: 10.1093/deafed/enu005

Maldonado, N. S. (2009). Technology in the classroom: How much technology knowledge does the average preschooler bring to the classroom?. Childhood Education, $86(2), 124-126$

Margaryan, A., Littlejohn, A., \& Vojt, G. (2011). Are digital natives a myth or reality? University students' use of digital technologies. Computers \& Education, 56(2), $429-440$.

Marschark, M., \& Spencer, P. A. (2003). Deaf studies, language, and education. New York, NY: Oxford University Press.

Marschark, M., \& Spencer, P. A. (2010). Evidence-based practice in educating deaf and hard-of-hearing students. New York, NY: Oxford University Press.

Marschark M., Nagel K., Shaver D.M., \& Newman L. (2015). Predicting the Academic Achievement of Deaf and Hard-of-Hearing Students from Individual, Household, Communication, and Educational Factors. Exceptional Children, 8, 350-369.

Massaro, D.W., \& Light, J. (2004). Using visible speech to train perception and production of speech for individuals with hearing loss. Journal of Speech, Language, and Hearing Research 47, 304-320. 
Mayer, C., Akamatsu, C.T., Marshark, M., \& Spencer, P. (2011). Bilingualism and literacy, The Oxford handbook of deaf studies, language, and education (2nd ed., Vol. 2). New York: Oxford University Press.

Means, B., Blando, J., Olson, K., Middleton, T., Morocco, C., Remz, A., \& Zorfass, J. (1993). Using technology to support education reform. U.S. Department of Education. Washington, DC: U.S. Department of Education, Office of Educational Research and Improvement. https://files.eric.ed.gov/fulltext/ED364220.pdf

Mercado, D. (2013). Instructional Design Strategies Used to Provide an Equal Learning Opportunity for Deaf and Hard of Hearing Learners. Journal of the American Deafness \& Rehabilitation Association (JADARA), 47(1), 147-163. Retrieved from http://www.libproxy.wvu.edu/login?url=http://search.ebscohost.com/login.aspx?d irect $=$ true $\& \mathrm{db}=\mathrm{a} 9 \mathrm{~h} \& \mathrm{AN}=92080629$

Mertens, D. M., \& Wang, Z. (1988). Attitudes toward computers of preservice teachers of hearing-impaired students. American Annals of the Deaf, 133(1), 40-42.

Mich, O., Pianta, E., \& Mana, N. (2013). Interactive stories and exercises with dynamic feedback for improving reading comprehension skills in deaf children. Computer and Education, 65, 35-44.

Mishra, P., Koehler, M. J., \& Henriksen, D. (2011). The seven trans-disciplinary habits of mind: Extending the TPACK framework towards 21 st century learning. Educational Technology, 51(2), 22-28. 
Mulder, D. J. (2016) Pre-Service teachers and technology integration: International cases and generational, In J. Keengwe, J.G. Mbae \& G. Onchwari (Eds.) Handbook of research on global issues in next-generation teacher education, (pp. 83-105). Pennsylvania, PA: Information Science Reference.

Nagel, D. (2008). Education technology spending to top $\$ 56$ billion by 2012. T.H.E. Journal: Technology Horizons in K-12 Education. (as cited in Mulder, 2016)

Nikolaraizi, M., \& Vekiri, I. (2011). The design of a software to enhance the reading comprehension skills of deaf students: an integration of multiple theoretical perspectives. Education and Information Technologies, 1-19. Retrieved from http://dx.doi.org/10.1007/s10639-011-9152-1.

Nulty, D. D. (2008). The adequacy of response rates to online and paper surveys: what can be done? Assessment \& Evaluation in Higher Education, 33(3), 301-314.

O'Bannon, B. W., \& Thomas, K. M. (2015). Mobile phones in the classroom: Preservice teachers answer the call. Computers \& Education, 85, 110-122.

O’Dwyer, L. M., Russell, M., \& Bebell, D. J. (2004). Identifying teacher, school, and district characteristics associated with elementary teachers' use of technology: A multilevel perspective. Education Policy Analysis Archives, 12(48).

Okuyama, Y., \& Iwai, M. (2011). Use of text messaging by deaf adolescents in Japan. Sign Language Studies, 11(3), 375-407. https://doiorg.www.libproxy.wvu.edu/10.1353/sls.2011.0001

Paivio, A. (2006). Mind and its evolution: A dual coding theoretical interpretation. Mahwah, NJ: Erlbaum. 
Part II. Educational Programs and Services. (1983). American Annals of the Deaf, 128(2), 133-243. Retrieved from http://www.jstor.org/stable/44400414

Parton, B. S. (2006). Sign language recognition and translation: A multidisciplined approach from the field of artificial intelligence. Journal of Deaf Studies and Deaf Education, (11)1, 94-101.

Parton, B. S., \& Hancock, R. (2008). When physical and digital worlds collide: A tool for early childhood learners. TechTrends, 52(5), 22-25.

Parton, B. S., \& Hancock, R. (2012). Animating the Inanimate using Aurasma: Applications for Deaf students. In Society for Information Technology \& Teacher Education International Conference, (pp. 3743- 3745). Chesapeake, VA: Association for the Advancement of Computing in Education (AACE).

Passig, D., \& Eden, S. (2000a). Enhancing the induction skill in deaf and hard-of-hearing children with virtual reality technology. Journal of Deaf Studies and Deaf Education, 5(3), 277-285.

Passig, D., \& Eden, S. (2000b). Improving flexible thinking in deaf and hard- of-hearing children with virtual reality technology. American Annals of the Deaf, 145(3), 286-291.

Passig, D., \& Eden, S. (2010). Enhancing time connectives with 3-D immersive virtual reality. Journal of Educational Computing Research 42(3), 307-325.

Paul, P. V. (2013). The Digital Generation: The Good, the Bad, and the Ugly. American Annals of the Deaf, 157(5), 407-411. 
Penuel, W. R. (2006). Implementation and effects of one-to-one computing initiatives: A research synthesis. Journal of Research on Technology in Education 38(3), 329348.

Pillai, P. (1999). Using technology to educate deaf and hard-of-hearing children in rural Alaskan general education settings. American Annals of the Deaf, 144(5), 373378.

Plester, B., Wood, C., \& Bell, V. (2008). Text message in school literacy: Does texting and knowledge of text abbreviations adversely affect children's literacy attainment? Literacy, (43), 137 - 144.

Plester, B., \& Wood, C. (2009). Exploring relationships between traditional and new media literacies: British preteen texters at school. Journal of Computer-Mediated Communication, (74), 1108-1129.

Plester, B., Wood, C., \& Joshi, P. (2009). Exploring the relationship between children's knowledge of text message abbreviations and school literacy outcomes. British Journal of Developmental Psychology, (27), 145-1 61.

Powers, D. A., \& Darrow, M. (1994). Special education and virtual reality: Challenges and possibilities. Journal of Research on Computing in Education, 27 (1), 111 .

Public Broadcasting Service. (2019). PBS. [Mobile application software]. Retrieved from https://www.pbs.org

Randles, J. (2016, March 19). Find out what the U.S. ed secretary thinks about ed tech, testing and digital equity. Retrieved March 31, 2016 from 
https://www.iste.org/explore/Lead-the-way/Find-out-what-the-U.S.-ed-secretarythinks-about-ed-tech,-testing-and-digital-equity

Rawson, G. (2016). Bridging the Digital Divide Bit by Bit. Capitol Ideas, 59(3), 38-41. Retrieved from http://www.libproxy.wvu.edu/login?url=http://search.ebscohost.com/login.aspx?d $\underline{\text { irect }}=$ true $\& \mathrm{db}=\mathrm{a} 9 \mathrm{~h} \& \mathrm{AN}=115194266$

Rea, L. M., \& Parker, R. A. (2014). Designing and Conducting Survey Research: A Comprehensive Guide ( $4^{\text {th }}$ ed.). San Francisco, CA: John Wiley \& Sons.

Reed, S., Antia, S., \& Kreimeyer, K. (2008). Academic status of deaf and hard-of-hearing students in public schools: Student, home, and service facilitators and detractors, The Journal of Deaf Studies and Deaf Education, 13(4), 485-502,

Reitsma, P (2009). Computer-based exercises for learning to read and spell by deaf children. Journal of Deaf Studies and Deaf Education, 14(2), 178-189. doi:10.1093/deafed/enn031

Roberson, L. (2001). Integration of computers and related technologies into deaf education teacher preparation programs. American Annals of the Deaf, 146(1), 6066.

Rogers, S. (2016). Bridging the $21^{\text {st }}$ Century Digital Divide. TechTrends: Linking Research \& Practice to Improve Learning, 60(3), 197-199. https://doiorg.www.libproxy.wvu.edu/10.1007/s11528-016-0057-0

Rose, S., \& Waldron, M. (1984). Microcomputer use in programs for hearing-impaired children: A national survey. American Annals of the Deaf, 129(3), 338-342. 
Rude, H., Jackson, L., Correa, S., Luckner, J., Muir, S., \& Ferrell, K. (2005). Perceived needs of students with low-incidence disabilities in rural areas. Rural Special Education Quarterly. 24(3), 3-14.

Sarchet, T., Marschark, M., Borgna, G., Convertino, C., Sapere, P. \& Dirmyer, R. (2014). Vocabulary knowledge and meta-knowledge in deaf and hearing students. Journal of Postsecondary Education and Disabilities, 17, 161-178.

Schirmer, B. R., \& McGough, S. M. (2005). Teaching reading to children who are deaf: Do the conclusions of the national reading panel apply? Review of Educational Research, 75(1), 83-117.

Shaver, D. M., Marschark, M., Newman, L., \& Marder, C. (2013). Who is where? Characteristics of deaf and hard-of-hearing students in regular and special schools. Journal of Deaf Studies and Deaf Education, 19(2), 203-219.

Shepherd, C. M., \& Alpert, M. (2015). Using technology to provide differentiated instruction for deaf learners. Journal of Instructional Pedagogies, 16.

Smith, C. E. (2006). Where Is It? How Deaf Adolescents Complete Fact-Based Internet Search Tasks. American Annals of the Deaf, 151(5), 519-529. doi:10.1353/aad.2007.0007

Smith, K. (2013). Imagine the possibilities: Bringing poster sessions to life through augmented reality. In R. McBride \& M. Searson (Eds.), Proceedings of Society for Information Technology \& Teacher Education International Conference 2013 (pp. 1734-1737). Chesapeake, VA: Association for the Advancement of Computing in Education (AACE). 
Smith, P. \& Brown, V. (2011). Mobile augmented reality as an emerging technology in education technology in education. In M. Koehler \& P. Mishra (Eds.), Proceedings of Society for Information Technology \& Teacher Education Teacher Education International Conference 2011 (pp. 3362-3365). Chesapeake, VA: Association for the Advancement of Computing in Education (AACE).

Snyder T.D., Dillow S.A. (2013). Digest of Education Statistics 2012. NCES 2014-015. Washington, DC: National Center for Education Statistics, Institute of Education Sciences, U.S. Department of Education.

Spencer, P. E., \& Marschark, M. (2010). Evidence-based practice in educating deaf and hard-of-hearing students. Oxford: Oxford University Press.

Stinson, M. S., Anita, S.D. (1999). Considerations in educating Deaf and Hard-of-Hearing students in inclusive settings. Journal of Deaf Studies and Deaf Education, 4(3), $163-175$.

Stinson, M. S., Elliot, L. B., Kelly, R. R., \& Yufang Liu. (2009). Deaf and Hard-ofHearing Students' Memory of Lectures with Speech-to-Text and Interpreting/Note Taking Services. The Journal of Special Education, 43(1), 5264. https://doi.org/10.1177/0022466907313453

Stinson, M.S, \& Kluwin, T.N. (2011). Educational consequences of alternative school placements. In M. Marschark \& P. Spencer (Eds.), The Oxford handbook of deaf studies, language, and education (Vol. 1). (2nd ed. pp. 47-62). New York, NY: Oxford University Press. 
Stoner, M. L., Easterbrooks, S. R., \& Laughton, J. M. (2005). Handwritten and wordprocessed story retellings by school-aged students who are deaf. Journal of Special Education Technology, 20(3), 35-AA.

Strassman, B. K., \& O'Dell, K. (2012). Using open captions to revise writing in digital stories composed by d/Deaf and hard-of-hearing students. American Annals of the Deaf 157(4), 340-357.

Stuckless, E. R., \& Carroll, J. K. (1994). National priorities on educational applications of technology for deaf and hard-of-hearing students. American Annals of the Deaf, $139(1), 62-63$.

Szarkowska, A., Krejtz, I., Klyszejko, Z., \& Wieczorek, A. (2011). Verbatim, standard, or edited? Reading patterns of different captioning styles among deaf, hard-ofhearing, and hearing viewers. American Annals of the Deaf 156(4), 363-378.

Taie, S., and Goldring, R. (2018). Characteristics of Public Elementary and Secondary School Teachers in the United States: Results From the 2015-16 National Teacher and Principal Survey First Look (NCES 2017-072rev). U.S. Department of Education. Washington, DC: National Center for Education Statistics.

Tamayo, A., \& Chaume, F. (2017). Subtitling for d/Deaf and Hard-of-Hearing Children: Current Practices and New Possibilities to Enhance Language Development. Brain Sciences (2076-3425), 7(7), 1-13. https://doiorg.www.libproxy.wvu.edu/10.3390/brainsci7070075

Teachers for the Deaf and HoH. (n.d.) Timeline [Facebook page]. Retrieved from https://www.facebook.com/groups/233972450075744/

The Radical Middle Project in Deaf Education. (n.d.) Timeline [Facebook page]. 
Retrieved from https:/www.facebook.com/groups/TheRadicalMiddleDHH/

Theobald, P. (2005). Urban and Rural Schools: Overcoming Lingering Obstacles. Phi Delta Kappan, 87(2), 116-122. Retrieved from http://www.libproxy.wvu.edu/login?url=http://search.ebscohost.com/login.aspx?d irect $=$ true $\& \mathrm{db}=\mathrm{a} 9 \mathrm{~h} \& \mathrm{AN}=18581556$

Thurlow, C., \& Brown, A. (2003). Generation txt? The sociolinguistics of young people's text-messaging. Discourse Analysis Online, (1), 1-27.

Thurlow, C., \& Poff, M. (2013). The language of text- messaging. In S. C. Herring, D. Stein \& T. Virtanen (Eds.), Handbook of the pragmatics of CMC (pp.163-190). Berlin and New York: Mouton de Gruyter.

Time USA, L.L.C. (2019). Time for Kids [Mobile application software]. Retrieved from https://www.timeforkids.com.

Trochim, W., \& Donnelly, J. P. (2006). The research methods knowledge base. Mason, OH: Atomic Dog Publishing.

U.S. Department of Education. (2016). Future ready learning: Reimagining the role of technology in education. Washington, DC: Office of Educational Technology. https://tech.ed.gov/files/2015/12/NETP16.pdf.

U.S. Department of Education. (2016). 38th annual report to Congress on the implementation of the Individuals with Disabilities Education Act, 2016. Washington, DC: Author.

U.S. Department of Education, Office of Educational Technology. (2017). Reimagining the Role of Technology in Education: 2017 National Education Technology Plan Update, Washington, D.C. 
Vehovar, V., \& Manfreda, K. L. (2008). Overview: Online surveys. In N. Fielding, R. M. Lee, \& G. Blank (Eds.), The SAGE handbook of online research methods (pp. 177-194). Thousand Oaks, CA: Sage Publishing.

Vesel, J. (2006). The Signing Science Dictionary research study report of findings. Washington, D.C.: National Center for Technology Innovation.

Vesel, J., \& Robillard, T. (2013). Teaching Mathematics Vocabulary with an Interactive Signing Math Dictionary. Journal of Research on Technology In Education (International Society For Technology In Education), 45(4), 361-389.

Vilorio, D. (2014). STEM 101: Intro to tomorrow's jobs. Occupational Outlook Quarterly, 58(1), 2-12.

Wang, Y., \& Paul, P. V. (2011). Integrating technology and reading instruction with children who are deaf or hard-of-hearing: The effectiveness of the Cornerstones Project. American Annals of the Deaf, 156(1), 56-68.

Ward, P., Wang, Y., Paul, P., \& Loeterman, M. (2007). Near-Verbatim Captioning Versus Edited Captioning for Students Who Are Deaf or Hard-of-hearing: A Preliminary Investigation of Effects on Comprehension. American Annals of the Deaf, 152(1), 20-28. Retrieved from http://www.jstor.org/stable/26234420

Yarger, C. C., \& Luckner, J. L. (1999). Itinerant teaching: The inside story. American Annals of the Deaf, 144, 309-314. 
Appendix A: E-mail/Cover Letter Script

Dear Participant,

This e-mail is a request for you to take part in an exciting research project to explore the current

frequency and types of technology currently used by teachers of deaf and hard-of hearing (d/hh) students for instruction and to promote communication and collaboration for learning.

This project is being conducted by Nichole K. Zirzow, MEd in the Department of Special Education at West Virginia University with supervision of Barbara Ludlow, Department Chair, West Virginia University, in the Department of Special Education, College of Education and Human Services. Your participation in this project is greatly appreciated and will take approximately 15 minutes to fill out the attached questionnaire.

Your involvement in this project will be kept as confidential as legally possible. All data will be reported in the aggregate. You must be 18 years of age or older to participate. I will not ask any information that should lead back to your identity as a participant. Your participation is completely voluntary. You may skip any question that you do not wish to answer, and you may discontinue at any time. There are no personal risks or benefits to you as a participant. West Virginia University's Institutional Review Board approval of this project is on file.

By clicking to begin the survey, you are consenting to the study.

I hope that you will participate in this research project, as it will be beneficial in understanding the use and challenges of technology in the changing landscape of deaf education. Please share this e-mail with other educators working with Deaf or Hard-ofHearing students. Thank you very much for your time. Should you have any questions about this letter or the research project, please feel free to contact Nichole K. Zirzow at (808) 651-9799 or by e-mail at nkzirzow@mix.wvu.edu.

Thank you for your time and help with this project.

Sincerely,

Nichole K. Zirzow, M.Ed 
Appendix B: Survey

\section{Using Technology with Students Who Are Deaf/Hard-of-Hearing}

1. I understand the risks and benefits outlined in the email and am at least 18 years of age. By clicking yes, I am consenting to participate.

2. How often do you use each of these for developing learning activities and materials for students who are deaf or hard-of-hearing $(\mathrm{d} / \mathrm{hh})$ ?

\begin{tabular}{|l|c|c|c|c|}
\hline & Frequently & Sometimes & Rarely & Never \\
\hline $\begin{array}{l}\text { Writing/Document software (Pages, } \\
\text { Word, etc.) }\end{array}$ & $\square$ & $\square$ & $\square$ & $\square$ \\
\hline $\begin{array}{l}\text { Presentation software } \\
\text { (PowerPoint; Keynote; Prezi, etc.) }\end{array}$ & $\square$ & $\square$ & $\square$ & $\square$ \\
\hline $\begin{array}{l}\text { Spreadsheet software (Excel, } \\
\text { Numbers etc.) }\end{array}$ & $\square$ & $\square$ & $\square$ & $\square$ \\
\hline $\begin{array}{l}\text { Video editing software } \\
\text { (MovieMaker, iMovie, etc.) }\end{array}$ & $\square$ & $\square$ & $\square$ & $\square$ \\
\hline $\begin{array}{l}\text { Photo editing software (iPhoto; } \\
\text { Paint; etc.) }\end{array}$ & $\square$ & $\square$ & $\square$ & $\square$ \\
\hline Other (please specify) & & & & \\
& & & & \\
\hline
\end{tabular}

If you answered "Other" to Question \#2 please specify what else you use for developing learning activities and materials here:

3. How often do you use each of the following to provide instruction to students who are deaf or hard-of-hearing (d/hh)?

\begin{tabular}{|l|c|c|c|c|c|c|}
\hline & Frequently & Sometimes & Rarely & Never & $\begin{array}{c}\text { I don't } \\
\text { know } \\
\text { what } \\
\text { this is }\end{array}$ & $\begin{array}{c}\text { I don't } \\
\text { have } \\
\text { access }\end{array}$ \\
\hline Text Messaging & $\square$ & $\square$ & $\square$ & $\square$ & $\square$ & $\square$ \\
\hline Email & $\square$ & $\square$ & $\square$ & $\square$ & $\square$ & $\square$ \\
\hline $\begin{array}{l}\text { Phone/Videophone (ooVoo; } \\
\text { Skype, etc.) }\end{array}$ & $\square$ & $\square$ & $\square$ & $\square$ & $\square$ & $\square$ \\
\hline $\begin{array}{l}\text { Social Media (Facebook, } \\
\text { Google+, Twitter, Snapchat, } \\
\text { Instagram, Tumbler, } \\
\text { Pinterest, etc.) }\end{array}$ & $\square$ & $\square$ & $\square$ & $\square$ & $\square$ & $\square$ \\
\hline $\begin{array}{l}\text { Search Engines (Google; } \\
\text { Bing Wikipedia, etc.) }\end{array}$ & $\square$ & $\square$ & $\square$ & $\square$ & $\square$ & $\square$ \\
\hline Word Processing (Word; & $\square$ & $\square$ & $\square$ & $\square$ & $\square$ & $\square$ \\
\hline
\end{tabular}




\begin{tabular}{|l|c|c|c|c|c|c|}
\hline Pages, etc) & & & & & & \\
\hline $\begin{array}{l}\text { Education Apps (News-o- } \\
\text { matic; Tinkerbox; Operation } \\
\text { Math etc.) }\end{array}$ & $\square$ & $\square$ & $\square$ & $\square$ & $\square$ & $\square$ \\
\hline $\begin{array}{l}\text { Posting Videos, Vlogs } \\
\text { (YouTube, TeacherTube, } \\
\begin{array}{l}\text { School Tube, Vemo, } \\
\text { Metacafe etc. }\end{array}\end{array}$ & $\square$ & $\square$ & $\square$ & $\square$ & $\square$ & $\square$ \\
\hline $\begin{array}{l}\text { Educational Videos } \\
\text { (Academic Earth, } \\
\text { Learner.org, PBS, Khan } \\
\text { Academy etc.) }\end{array}$ & $\square$ & $\square$ & $\square$ & $\square$ & $\square$ & $\square$ \\
\hline $\begin{array}{l}\text { Academic Services (iReady, } \\
\text { Achieve3000, eSparkt etc.) }\end{array}$ & $\square$ & $\square$ & $\square$ & $\square$ & $\square$ & $\square$ \\
\hline $\begin{array}{l}\text { News/information website } \\
\text { (e.g. CNN; Yahoo; etc.) }\end{array}$ & $\square$ & $\square$ & $\square$ & $\square$ & $\square$ & $\square$ \\
\hline $\begin{array}{l}\text { ASL Dictionary (Signing } \\
\text { Savvy; Handspeak; ASL } \\
\text { Browser, etc. ) }\end{array}$ & $\square$ & $\square$ & $\square$ & $\square$ & $\square$ & $\square$ \\
\hline $\begin{array}{l}\text { Virtual Immersion (Second } \\
\text { Life, Whyville, OpenSim, } \\
\text { virtual manipulatives etc.) }\end{array}$ & $\square$ & $\square$ & $\square$ & $\square$ & $\square$ & $\square$ \\
\hline $\begin{array}{l}\text { Learning Management } \\
\text { System (Moodle, Edmodo, } \\
\text { Blackboard etc. }\end{array}$ & $\square$ & $\square$ & $\square$ & $\square$ & $\square$ & $\square$ \\
\hline $\begin{array}{l}\text { Virtual Assistants/Agents } \\
\text { (3D Signing Avatars, } \\
\text { Chatbots etc.) }\end{array}$ & $\square$ & $\square$ & $\square$ & $\square$ & $\square$ & $\square$ \\
\hline $\begin{array}{l}\text { Podcasts/Vodcasts (iTunes, } \\
\text { podOmatic, Juice, } \\
\text { Educational Podcasts etc.) }\end{array}$ & $\square$ & $\square$ & $\square$ & $\square$ & $\square$ & $\square$ \\
\hline $\begin{array}{l}\text { Educational services } \\
\text { (Scholastic, BrainPop, } \\
\text { Cosmeo etc.) }\end{array}$ & $\square$ & $\square$ & $\square$ & $\square$ & $\square$ & $\square$ \\
\hline
\end{tabular}

If you answered "Other" to Question \#3 please specify what else you use to provide instruction here:

4. What websites or apps. do you use most often for providing instruction to deaf or hardof-hearing students? 
5. How often do you use each of the following to support communication with students who are deaf or hard-of-hearing or support access to learning materials?

\begin{tabular}{|c|c|c|c|c|c|c|}
\hline & Frequently & Sometimes & Rarely & Never & $\begin{array}{c}\text { I don't } \\
\text { know } \\
\text { what that } \\
\text { is }\end{array}$ & $\begin{array}{l}\text { I don't } \\
\text { have } \\
\text { access }\end{array}$ \\
\hline Laptop & $\square$ & $\square$ & $\square$ & $\square$ & $\square$ & $\square$ \\
\hline iPad or Tablet & $\square$ & $\square$ & $\square$ & $\square$ & $\square$ & $\square$ \\
\hline $\begin{array}{l}\text { Smart Phone (iPhone, } \\
\text { Droid, Blackberry, etc.) }\end{array}$ & $\square$ & $\square$ & $\square$ & $\square$ & $\square$ & $\square$ \\
\hline $\begin{array}{l}\text { Augmentative } \\
\text { Communication Device } \\
\text { (Dynovox; Go Talk, etc.) }\end{array}$ & $\square$ & $\square$ & $\square$ & $\square$ & $\square$ & $\square$ \\
\hline $\begin{array}{l}\text { Translation Apps } \\
\text { (iTranslate; ASL } \\
\text { Translator; Mimex, etc.) }\end{array}$ & $\square$ & $\square$ & $\square$ & $\square$ & $\square$ & $\square$ \\
\hline Overhead Projector/ELMO & $\square$ & $\square$ & $\square$ & $\square$ & $\square$ & $\square$ \\
\hline $\begin{array}{l}\text { Interactive Whiteboard } \\
\text { (SMART, Promethean, } \\
\text { MIMIO etc.) }\end{array}$ & $\square$ & $\square$ & $\square$ & $\square$ & $\square$ & $\square$ \\
\hline $\begin{array}{l}\text { Student/Learner } \\
\text { Response System }\end{array}$ & $\square$ & $\square$ & $\square$ & $\square$ & $\square$ & $\square$ \\
\hline $\begin{array}{l}\text { Captioning and Text } \\
\text { Interpreting (CART, C- } \\
\text { Print, TypeWell etc.) }\end{array}$ & $\square$ & $\square$ & $\square$ & $\square$ & $\square$ & $\square$ \\
\hline $\begin{array}{l}\text { Video Remote Interpreting } \\
\text { (VRI) }\end{array}$ & $\square$ & $\square$ & $\square$ & $\square$ & $\square$ & $\square$ \\
\hline $\begin{array}{l}\text { Closed or Open } \\
\text { Captioning }\end{array}$ & $\square$ & $\square$ & $\square$ & $\square$ & $\square$ & $\square$ \\
\hline Other (please specify) & $\square$ & $\square$ & $\square$ & $\square$ & $\square$ & $\square$ \\
\hline
\end{tabular}

If you answered "Other" to Question \#5 please specify what else you use for communication/access here:

6. How often do you use each of the following for collaborating with professional colleagues, family members, or students about programing for students who are deaf or hard-ofhearing?

\begin{tabular}{|l|c|c|c|c|}
\hline & Frequently & Sometimes & Rarely & Never \\
\hline Text Messaging & $\square$ & $\square$ & $\square$ & $\square$ \\
\hline E-Mail & $\square$ & $\square$ & $\square$ & $\square$ \\
\hline $\begin{array}{l}\text { Phone/Videophone (ooVoo; Skype, } \\
\text { etc.) }\end{array}$ & $\square$ & $\square$ & $\square$ & $\square$ \\
\hline $\begin{array}{l}\text { Social Media (Facebook, Google+, } \\
\text { Twitter, Snapchat, Instagram, } \\
\text { Tumbler, Pinterest) }\end{array}$ & $\square$ & $\square$ & $\square$ & $\square$ \\
\hline School website/ Class Webpage & $\square$ & $\square$ & $\square$ & $\square$ \\
\hline $\begin{array}{l}\text { Professional Deaf specific } \\
\text { Association websites }\end{array}$ & $\square$ & $\square$ & $\square$ & $\square$ \\
\hline $\begin{array}{l}\text { Organizational Websites (Google } \\
\text { Drive; Evernote; Dropbox; Catch; } \\
\text { Springpad; Bento, etc.) }\end{array}$ & $\square$ & $\square$ & $\square$ & $\square$ \\
\hline
\end{tabular}




\begin{tabular}{|l|c|c|c|c|}
\hline $\begin{array}{l}\text { Presentation software (Power } \\
\text { Point; Prezi; Keynote, etc.) }\end{array}$ & $\square$ & $\square$ & $\square$ & $\square$ \\
\hline $\begin{array}{l}\text { Word Processing (Word; Pages, } \\
\text { etc) }\end{array}$ & $\square$ & $\square$ & $\square$ & $\square$ \\
\hline Other (please specify) & $\square$ & $\square$ & $\square$ & $\square$ \\
\hline
\end{tabular}

If you answered "Other" to Question \#6 please specify what else you use for collaboration here:

7. How often do you use each of the following standards do you use to guide your use of technology for instruction of students who are deaf or hard-of-hearing?

\begin{tabular}{|l|c|c|c|c|}
\hline & Frequently & Sometimes & Rarely & Never \\
\hline $\begin{array}{l}\text { National Education Technology } \\
\text { Standards (NETS) }\end{array}$ & $\square$ & $\square$ & $\square$ & $\square$ \\
\hline $\begin{array}{l}\text { State Education Technology } \\
\text { Standards }\end{array}$ & $\square$ & $\square$ & $\square$ & $\square$ \\
\hline Framework for 21 st $^{\text {Century Skills }}$ & $\square$ & $\square$ & $\square$ & $\square$ \\
\hline $\begin{array}{l}\text { Technology Assessment of Deaf } \\
\text { and Hard-of-hearing Students }\end{array}$ & $\square$ & $\square$ & $\square$ & $\square$ \\
\hline $\begin{array}{l}\text { TESOL Technology Standards } \\
\text { Framework }\end{array}$ & $\square$ & $\square$ & $\square$ & $\square$ \\
\hline $\begin{array}{l}\text { Mayors 12 principles of Multimedia } \\
\text { Learning }\end{array}$ & $\square$ & $\square$ & $\square$ & $\square$ \\
\hline $\begin{array}{l}\text { Framework for teacher knowledge } \\
\text { of Technology, Pedagogy, and } \\
\text { Content Knowledge (TPACK) }\end{array}$ & $\square$ & $\square$ & $\square$ & $\square$ \\
\hline
\end{tabular}

8. Which of the following challenges do you face in your use of technology?

\begin{tabular}{|l|c|c|c|c|}
\hline & Frequently & Sometimes & Rarely & Never \\
\hline Hardware absent or outdated & $\square$ & $\square$ & $\square$ & $\square$ \\
\hline Software absent or outdated & $\square$ & $\square$ & $\square$ & $\square$ \\
\hline No internet Access & $\square$ & $\square$ & $\square$ & $\square$ \\
\hline No WIFl Access & $\square$ & $\square$ & $\square$ & $\square$ \\
\hline No or inadequate training & $\square$ & $\square$ & $\square$ & $\square$ \\
\hline No or inadequate funding & $\square$ & $\square$ & $\square$ & $\square$ \\
\hline Fear of using new technology & $\square$ & $\square$ & $\square$ & $\square$ \\
\hline Lack of time for training or practice & $\square$ & $\square$ & $\square$ & $\square$ \\
\hline Student literacy level & $\square$ & $\square$ & $\square$ & $\square$ \\
\hline Student disinterest or resistance & $\square$ & $\square$ & $\square$ & $\square$ \\
\hline Family disinterest or resistance & $\square$ & $\square$ & $\square$ & $\square$ \\
\hline Other (please specify) & $\square$ & $\square$ & $\square$ & $\square$ \\
\hline
\end{tabular}

If you answered "Other" to Question \#8 please specify what else you use for communication/access here:

9. If there was one thing web or app designers could do to improve access for Deaf/HH students, what would it be? 
10. Gender with which you most identify:
Male
Female

11. Your age in years:
25 or younger
$\square$ 26-35
$36-45$
46-55
over 55

12. Highest level at which you obtained your training in deaf education:

BA/BS $\square \mathrm{MA} / \mathrm{MS} / \mathrm{MEd} \quad \square \mathrm{PhD/EdD} \quad \square$ Other

13. Please indicate what format your deaf education preservice program/training was provided (mark all that apply:
Traditional
Online
Hybrid

14. Please indicate the setting(s) in which you currently teach:

$\square$ Resource Room $\square$ Itinerant $\square$ College Faculty

15. Please indicate the environment that best describes where you teach:

$\square$ Urban $\quad \square$ Suburban $\quad \square$ Rural

16. Level of your students (mark all that apply):

$\square$ Pre-K $\square$ Elementary $\quad \square$ Secondary $\quad \square$ Post-Secondary

17. Communication approach/method of your district/school:

$\square$ Signed English (no voice) $\square$ Speech and Sign $\square$ ASL $\quad \square$ Speech only

18. Means by which you obtain professional development training in the use of technology for use with deaf/hard-of-hearing students (mark all that apply)

District $\square$ School (Technology Teacher, Workshops) 
$\square$ Personally (Online/Face-to-Face Classes, Workshops, Conferences) $\quad \square$ Other $\square$ Not at all

If you answered "Other" to Question \#18 please specify how else you obtain professional development here:

19. How often do you receive professional development in the use of instructional technology for use with deaf/hard-of-hearing students?
Annually
Semi-Annually
Other
Not at all

If you answered "Other" to Question \#19 please specify how often you obtain professional development here:

Thank you so much for completing the survey! 
Appendix C: Demographic Table

Demographic

Gender

Male

Female

Missing
Percentage of sample

8.4

56.6

35

2.4

14.4

16

17.3

15.2

34.7

13.6

47.4

3.3

35.8

86.86

6.36

11.02

36.00

63.47

16.44

21.00

4.57

40.7

Missing

Environment

Urban

26.30

26.80

11.90

35.00

Missing

\section{Level of your students}

Pre-K

30.80

Elementary

52.74

Secondary

57.38

Post-Secondary

11.39

Missing 
Communication mode of your

district/school:

Signed English (no voice)

Speech and Sign (Total

.3

Communication/SimCom)

23.8

ASL

32.2

Speech only

8.9

Missing

34.7

Means by which obtain professional

development Training

Preservice (College Classes)

22.59

District

30.13

School (Technology Teacher,

74.90

Workshops)

Personally (Online, Workshops,

58.58

Conferences)

Other

5.44

Not at all

4.18

Missing

35.20

How often do you receive professional development

Annually

18.4

Semi-Annually

8.4

Quarterly

7.0

Other

12.5

Not at all

18.4

Missing

35.2 